Portland State University

PDXScholar

1990

\title{
Analysis and Numerical Simulation of the Ground Water System at the Bonneville Navigation Lock Site, Oregon
}

Dirk Baron

Portland State University

Follow this and additional works at: https://pdxscholar.library.pdx.edu/open_access_etds

Part of the Geology Commons, and the Hydrology Commons Let us know how access to this document benefits you.

Recommended Citation

Baron, Dirk, "Analysis and Numerical Simulation of the Ground Water System at the Bonneville Navigation Lock Site, Oregon" (1990). Dissertations and Theses. Paper 4027.

https://doi.org/10.15760/etd.5911

This Thesis is brought to you for free and open access. It has been accepted for inclusion in Dissertations and Theses by an authorized administrator of PDXScholar. Please contact us if we can make this document more accessible: pdxscholar@pdx.edu. 
AN ABSTRACT OF THE THESIS OF Dirk Baron for the Master of Science in Geology presented April 12, 1990.

Title: Analysis and Numerical Simulation of the Ground Water System at the Bonneville Navigation Lock Site, Oregon.

APPROVED BY THE MEMBERS OF THE THESIS COMMITTEE:
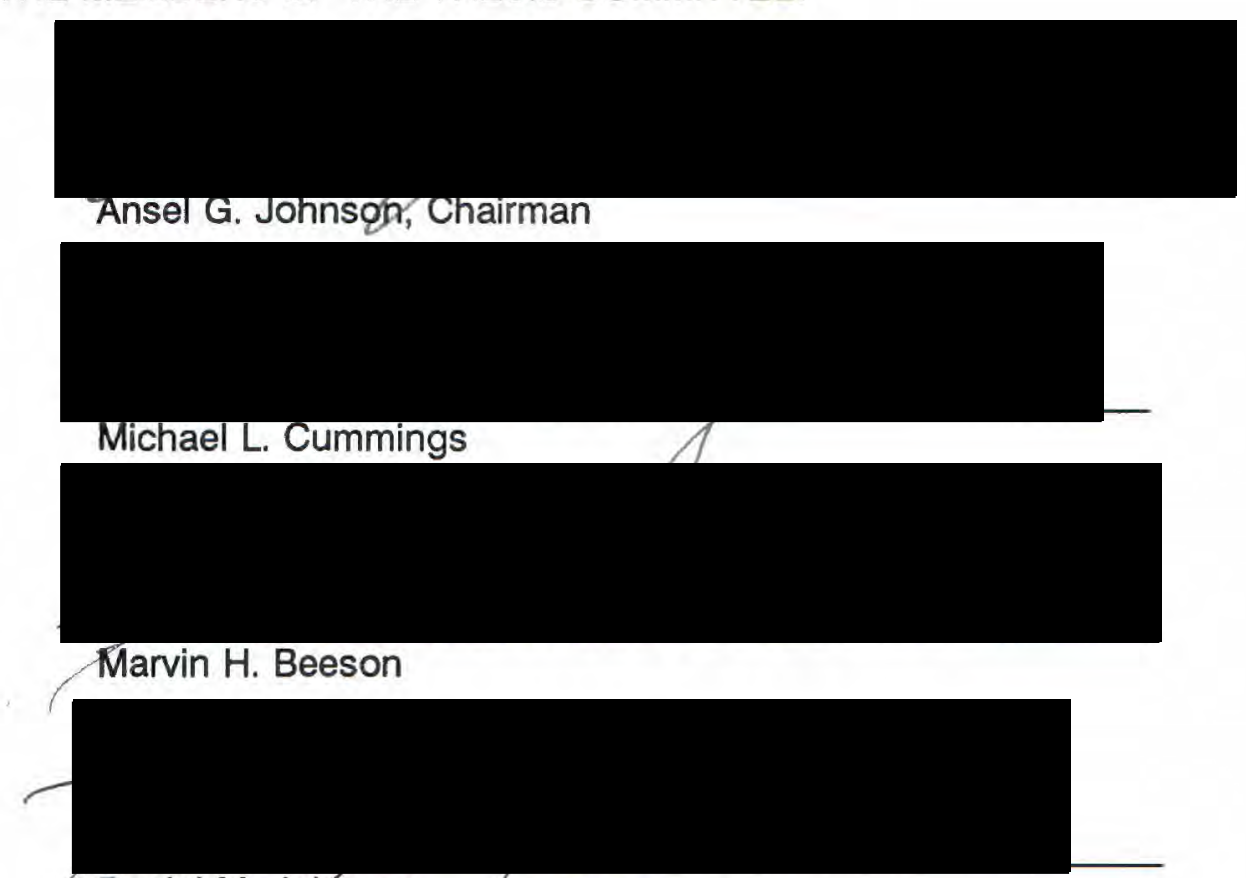

Daniel M. Joknson

As part of the new navigation lock for Bonneville Dam a new water source for the Bonneville Fish Hatchery must be supplied. The hatchery is located on the Oregon side of the Columbia River downstream of the dam. It requires large quantities of water free from chemical and biological contamination. In addition, the water has to be in a narrow temperature range. Currently the fish hatchery receives its water from a well field that is located on the alluvial terrace downstream of 
Bonneville Dam. The well field lies in the proposed approach channel for the new lock and has to be abandoned during construction of the lock. For the continued water supply of the hatchery, a new well field will be developed north of the approach channel. Early in the planning phase for the new lock, concerns were raised about the potential impact of the relocation of the well field and the excavation of the new approach channel on the hatchery. To assess these concerns and to assure a continuous water supply during and after construction, a hydrogeologic investigation was initiated. Within the framework of the investigation this study focuses on the analysis of pumping test data and the development of a three-dimensional ground water flow model for the site.

In the first phase of the study, data from eight pumping tests were analyzed. Hydrogeologic properties of the sedimentary units that make up the downstream terrace were determined. The focus was the pre-slide alluvium (PSA) aquifer, the water source for the existing and the future well field. In addition, the nature and location of hydrogeologic boundaries for the ground water system were determined. The results, in conjunction with information from subsurface exploration and laboratory tests, were used to develop a conceptual understanding of the ground water system at the site. The PSA aquifer receives its recharge primarily from leakage through the overlying confining layers over a large area. A direct connection between the Columbia River and the PSA aquifer could not be detected. They appear to be separated by a continuous aquitard layer or by a layer of fine-grained sediments on the river bottom.

Based on these findings, in the second phase of the study, the ground water modeling program HST3D (Kipp, 1987) was used to develop a three-dimensional 
ground water model for the site. The model was calibrated with data from one of the pumping tests. The calibration was then verified with a second set of conditions including pumping from shallow and deep wells. Water levels in the deep PSA aquifer and the shallow unconfined aquifer were successfully matched. A satisfactory match of observed conditions was possible with only slight modifications of the hydrogeologic parameters determined by pumping test analysis and based on the conceptual model developed in the first phase of the study. It appears that a continuous aquitard layer separating the Columbia River and the PSA aquifer, with the aquifer receiving recharge through vertical leakage over a large area, is a valid representation of the aquifer system. 
ANALYSIS AND NUMERICAL SIMULATION OF THE GROUND WATER SYSTEM AT THE BONNEVILLE NAVIGATION LOCK SITE, OREGON

by

DIRK BARON

A thesis submitted in partial fulfillment of the requirements for the degree of

\section{MASTER OF SCIENCE \\ in GEOLOGY}

Portland State University 1990 
TO THE OFFICE OF GRADUATE STUDIES:

The members of the Committee approve the thesis of Dirk Baron presented April 12, 1990.

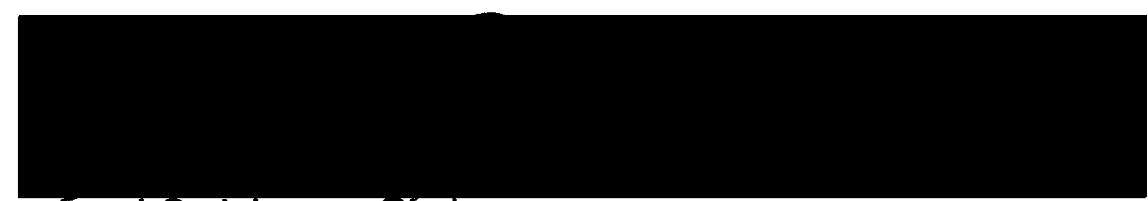

Ansel G. Johnson, Tehairman

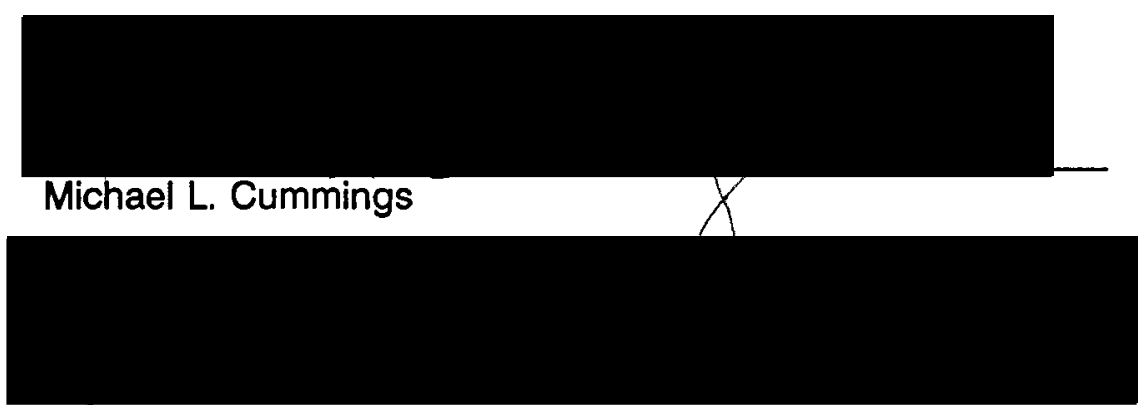

Márvin H. Beeson

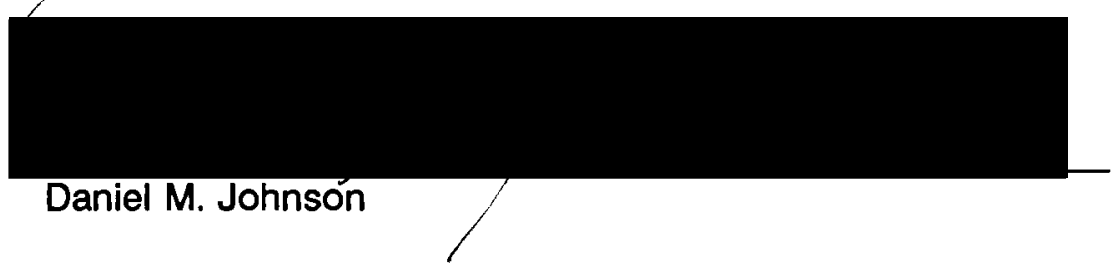

APPROVED:

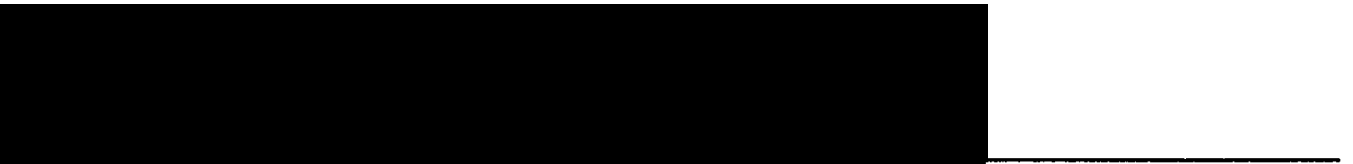

Ansel G. Johnson, Chair, Department of Geology

C. William Savery, Interim Vice Provost for Graduate Studies and Research 


\section{ACKNOWLEDGEMENTS}

I would like to thank all the faculty, staff and students of the Geology

Department. I have learned a lot during my time at Portland State University, and I have also found a great group of people.

A lot of people have helped in one form or another throughout the thesis project. I am grateful to all of them. There are a few people I want to point out in particular. I am grateful to my advisor Ansel Johnson for his support, encouragement and advice throughout my studies and the thesis project. Special thanks also go to Jim Graham for his help in getting this project going and keeping it going against all administrative odds, and for sharing his office space. David Scofield has been a great source for information on the Bonneville Navigation Lock project and on the geology of the Bonneville area. Dave, Mike Cummings, Marvin Beeson and Daniel Johnson have reviewed the thesis and provided valuable comments and suggestions. Ken Kipp from the USGS has been very helpful with some of the more complicated aspects and bugs of HST3D. John Phillips has provided help and advice with the illustrations.

Funding for this project was provided by the Corps of Engineers, Portland District through a research assistantship and a contract with L.R. Squier Associates. 


\section{TABLE OF CONTENTS}

PAGE

ACKNOWLEDGEMENTS $\ldots \ldots \ldots \ldots \ldots \ldots \ldots \ldots \ldots \ldots$ iii

LIST OF TABLES $\ldots \ldots \ldots \ldots \ldots \ldots \ldots \ldots \ldots \ldots \ldots \ldots \ldots \ldots$ vii

LIST OF FIGURES $\ldots \ldots \ldots \ldots \ldots \ldots \ldots \ldots \ldots \ldots \ldots \ldots$ viii

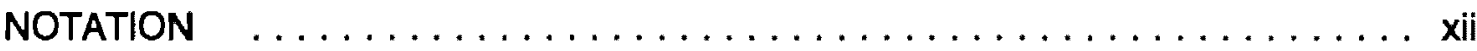

\section{CHAPTER}

I INTRODUCTION $\ldots \ldots \ldots \ldots \ldots \ldots \ldots \ldots \ldots \ldots \ldots$

General $\ldots \ldots \ldots \ldots \ldots \ldots \ldots \ldots \ldots \ldots \ldots \ldots$

Purpose and Scope $\ldots \ldots \ldots \ldots \ldots \ldots \ldots \ldots$

Sources of Information $\ldots \ldots \ldots \ldots \ldots \ldots \ldots, 5$

$\| \quad$ GEOLOGY AND HYDROGEOLOGY $\ldots \ldots \ldots \ldots \ldots \ldots \ldots, \boldsymbol{9}$

Regional Geology $\ldots \ldots \ldots \ldots \ldots \ldots \ldots \ldots$

Terrace Deposits . . . . . . . . . . . . . 10

Pre-Slide Alluvium (PSA)

Mica Sand (MS)

B-Unit (BU)

River Deposits (RD)

Hydrogeology $\ldots \ldots \ldots \ldots \ldots \ldots \ldots \ldots \ldots \ldots \ldots$

III PUMPING TEST ANALYSIS $\ldots \ldots \ldots \ldots \ldots \ldots \ldots \ldots \ldots$

Sources of Recharge to the PSA Aquifer $\ldots \ldots \ldots \ldots 18$

Method of Images

Observations in Piezometer $\mathrm{HI}-1$ 
Response of the Shallow Aquifer to Pumping Discussion

Methods of Pumping Test

Pumping Tests 27

Fish Hatchery Wells $\mathrm{H}-3$ and $\mathrm{H}-4$ (PSA Aquifer)

A-2, PSA Aquifer

Other Pumping Tests in the PSA Aquifer

A-1 (Mica Sand)

Vertical Leakage $\ldots \ldots \ldots \ldots \ldots \ldots \ldots \ldots \ldots$

Boundaries $\ldots \ldots \ldots \ldots \ldots \ldots \ldots \ldots \ldots \ldots \ldots$

Summary of Hydrogeologic Parameters for the

Alluvial Units ................... 35

IN CONCEPTUAL MODEL OF THE GROUND WATER SYSTEM $\ldots \ldots, 67$

Conceptualization $\ldots \ldots \ldots \ldots \ldots \ldots \ldots \ldots \ldots 67$

Criteria for the Computer Model $\ldots \ldots \ldots \ldots \ldots \ldots 68$

v COMPUTER MODELING $\ldots \ldots \ldots \ldots \ldots \ldots \ldots \ldots \ldots$

Discretization $\ldots \ldots \ldots \ldots \ldots \ldots \ldots \ldots \ldots \ldots$

Model Geometry

Hydrogeologic Units

Water Wells

Boundary Conditions

Initial Conditions

Summary of Assumptions $\ldots \ldots \ldots \ldots \ldots \ldots \ldots 73$

Ground Water Flow Calibration $\ldots \ldots \ldots \ldots \ldots \ldots 74$

Calibration

Verification

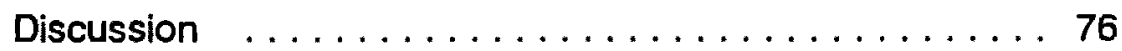

VI CONCLUSIONS AND RECOMMENDATIONS $\ldots \ldots \ldots \ldots \ldots 9$

Summary $\ldots \ldots \ldots \ldots \ldots \ldots \ldots \ldots \ldots \ldots \ldots$ 
Applications of the Model $\ldots \ldots \ldots \ldots \ldots$

Conclusions $\ldots \ldots \ldots \ldots \ldots \ldots \ldots \ldots$

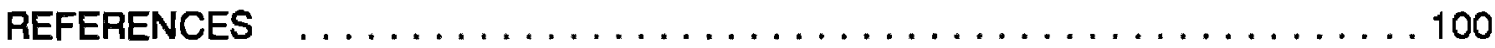
APPENDICES

A PIEZOMETER AND WELL INFORMATION $\ldots \ldots \ldots \ldots \ldots \ldots 103$

B CALCULATIONS FOR THE RATIO METHOD $\ldots \ldots \ldots \ldots \ldots 106$

C GEOMETRY OF THE COMPUTER MODEL . . . . . . . . . . 109 


\section{LIST OF TABLES}

TABLE

PAGE

I Image Well Method, Calculated Distances to Image Wells and

Distance to Pumping Well for Pumping Test $\mathrm{H}-4 \ldots \ldots 37$

II Response of Selected Shallow Piezometers to Changes in the

Pumping Rate from the Hatchery Wells $\ldots \ldots \ldots \ldots 38$

III Results from Different Pumping Test Analysis Methods,

Pumping Wells $\mathrm{H}-3$ and $\mathrm{H}-4 \ldots \ldots \ldots \ldots \ldots \ldots$

IV Summary of Results of Pumping Test Analysis for the PSA Aquifer . 40

V Vertical Hydraulic Conductivity of the Aquitard Layers B-Unit and Mica Sand, Hantush-Jacob Method $\ldots \ldots \ldots \ldots \ldots 41$

VI Properties of Hydrogeologic Units Used for Initial Model Input . . . 77

VII Water Wells Included in the Computer Model $\ldots \ldots \ldots \ldots . \ldots 78$

VIII Horizontal and Vertical Hydraulic Conductivities Used in

Model Runs Simulating Pumping Test $\mathrm{H}-4 \quad \ldots \ldots \ldots 79$

IX Hydraulic Conductivities Used in Ground Water Flow Calibration and Verification Model Runs $\ldots \ldots \ldots \ldots \ldots \ldots$

X Properties of Hydrogeologic Units Assigned after Model

Calibration and Verification $\ldots \ldots \ldots \ldots \ldots \ldots \ldots 1$ 


\section{LIST OF FIGURES}

FIGURE

PAGE

1. Map of the Vicinity of Bonneville Dam on the Columbia River,

Oregon Washington $\ldots \ldots \ldots \ldots \ldots \ldots \ldots \ldots$

2. Site Plan of the Downstream Terrace Area at Bonneville Dam

with the Proposed New Navigation Lock, and

Piezometer and Well Locations $\ldots \ldots \ldots \ldots \ldots \ldots 8$

3. Geologic Map of the Vicinity of Bonneville Dam $\ldots \ldots \ldots \ldots 16$

4. Representative Geologic Cross-Section of the Downstream

Terrace Area $\ldots \ldots \ldots \ldots \ldots \ldots \ldots \ldots \ldots \ldots 17$

5. Time-Drawdown Plot from Piezometer 1612-Z1 During the

Pumping Test in Fish Hatchery Well $\mathrm{H}-3 \ldots \ldots \ldots \ldots 42$

6. Representation of a Hydrogeologic Recharge Boundary with an Image Well $\ldots \ldots \ldots \ldots \ldots \ldots \ldots \ldots \ldots \ldots$

7. Image Well Method, Determination of the Distance to an Image Well $\ldots \ldots \ldots \ldots \ldots \ldots \ldots \ldots \ldots \ldots, 44$

8. Image Well Method, Determination of the Location of a

Hypothetical Image Well for Pumping Test $\mathrm{H}-4 \ldots \ldots .45$

9. Water Level in Piezometer $\mathrm{HI}-1$ and Columbia River Stage during the Period from July 20 to August $1,1988 \ldots \ldots \ldots$. 46

10. Effect of Turning Off Hatchery Well $\mathrm{H}-3$ on Piezometer $\mathrm{HI}-1 \ldots 47$ 
11. Effect of Different Columbia River Stage Changes on the Water Level in the Aquifer 48

12. Correction of the Water Level in Piezometer $\mathrm{HI}^{-1}$ for the Influence of Fluctuations of the Columbia River Stage $\ldots \ldots \ldots 49$

13. Recovery of the Water Level in Piezometer HI-1 after Turning Off Hatchery Well $\mathrm{H}-3 \ldots \ldots \ldots \ldots \ldots \ldots \ldots$

14. Scenarios for the Interaction of a River and a Confined Aquifer . . 51

15. Leaky Aquifer System $\ldots \ldots \ldots \ldots \ldots \ldots \ldots \ldots \ldots \ldots \ldots$

16. $W(u, r / B)$ Type Curves for Leaky Aquifers $\ldots \ldots \ldots \ldots \ldots$

17. Determination of Aquifer Parameters with the Hantush-Jacob Method for Leaky Aquifers 54

18. Reversed Theis Type Curve $\ldots \ldots \ldots \ldots \ldots \ldots \ldots \ldots \ldots$

19. Determination of Aquifer Parameters with the Theis Method ... 56

20. Determination of Aquifer Parameters with the Jacob-Semilog Method

21. Columbia River Stage during the Pumping Tests in Wells $\mathrm{H}-3$ and $\mathrm{H}-4 \ldots \ldots \ldots \ldots \ldots \ldots \ldots \ldots \ldots \ldots$

22. Columbia River Stage during the Pumping Test in Well A-2 . . . . 59

23. Pumping Test A-2, Time-Drawdown Plot for Piezometer 1746-Z1 .. 60

24. Correction of Water Level in Piezometer $1746-Z 1$ for the Columbia River Stage Fluctuation $\ldots \ldots \ldots \ldots \ldots \ldots .61$

25. Water Level in Piezometer 1746-Z1 Corrected for the Influence of the Columbia River Stage Fluctuation $\ldots \ldots \ldots \ldots \ldots 62$ 
26. First Pumping Test in Well A-1, Time-Drawdown Plot and Columbia River Stage 63

27. Second Pumping Test in Well A-1, Time-Drawdown Plot and Columbia River Stage $\ldots \ldots \ldots \ldots \ldots \ldots \ldots \ldots 64$

28. Areal Distribution of Transmissivity of the PSA Aquifer $\ldots \ldots \ldots 65$

29. Areal Distribution of Hydraulic Conductivity of the

PSA Aquifer $\ldots \ldots \ldots \ldots \ldots \ldots \ldots \ldots \ldots 6$

30. Map of the Vicinity of Bonneville Dam with the Outline of the

Computer Model Grid

31. Downstream Terrace Area with an Overlay of the

Computer Model Grid

32. View of the Three-Dimensional Computer Grid $\ldots \ldots \ldots \ldots$. . . 84

33. Top View of the Computer Model Grid $\ldots \ldots \ldots \ldots \ldots \ldots$

34. Results of Simulation of Pumping Test $\mathrm{H}-4$ : Water Well $\mathrm{H}-4 \ldots 68$

35. Results of Simulation of Pumping Test H-4: Piezometer $1611 \ldots 87$

36. Results of Simulation of Pumping Test H-4: Piezometer $1615 \ldots 88$

37. Results of Simulation of Pumping Test H-4: Piezometer $1624 \ldots 89$

38. Results of Simulation of Pumping Test H-4: Observation Well WW-1794 ........................ 90

39. Results of Simulation of Pumping Test H-4: Observation Well H-5 . 91 40. Results of Simulation of Pumping Test H-4: Piezometer HI-1 _. 92 41. Measured Water Levels in the PSA Aquifer on

September $12,1989 \ldots \ldots \ldots \ldots \ldots \ldots \ldots \ldots \ldots \ldots .93$ 
42. Measured Water Levels in the Shallow Unconfined Aquifer

on September 12, 1989

43. Simulation of Conditions on September 12, 1989:

Calculated Water Levels in the PSA Aquifer 95

44. Simulation of Conditions on September 12, 1989: Calculated

Water Levels in the Shallow Unconfined Aquifer . . . . . . 96 


\section{- NOTATION}

Parameters with Units of Measurement:

b

thickness of the aquifer [m]

b'

thickness of the aquitard [m]

E

filter coefficient for the leaky integrator

h

hydraulic head [m]

$h_{0}$

initial hydraulic head [m]

$h_{1}$

hydraulic head during pumping [m]

K

hydraulic conductivity of the aquifer $[\mathrm{m} / \mathrm{s}]$

$K^{\prime}$

hydraulic conductivity of the aquitard $[\mathrm{m} / \mathrm{s}]$

Q

pumping rate $\left[\mathrm{m}^{3} / \mathrm{s}\right]$

$r$

radial distance from a piezometer to the pumping well [m]

$r / B$

leakage factor (dimensionless)

S

aquifer storativity

s

drawdown [m]

T

aquifer transmissivity $\left[\mathrm{m}^{2} / \mathrm{s}\right]$

t

time [s]

$\mathbf{U}$

parameter for the well function

$\mathrm{W}(\mathrm{u}) \quad$ well function

$\mathrm{W}(\mathrm{u}, \mathrm{r} / \mathrm{B}) \quad$ well function for leaky aquifers

$\mathbf{x}$

distance from a well to a hydrogeologic boundary [m]

$Y(l)$

leaky integrator, unfiltered river stage [m] 
$Z(I) \quad$ leaky integrator, filtered river stage

Geologic Units:

BU b-unit, undifferentiated

BC silt and clay subunit of the b-unit

BG sand and gravel subunit of the b-unit

BRI Bonney Rock intrusive

MS mica sand

PSA pre-slide alluvium

RD river deposits

SB slide block

SD slide debris

RSD reworked slide debris

TCA Tanner Creek alluvium

TCR Columbia River Basalt Group

TEC Eagle Creek Formation

TW Weigle formation 
CHAPTER I

INTRODUCTION

\section{GENERAL}

The Bonneville Fish Hatchery, located on the Oregon shore of the Columbia River downstream of Bonneville Dam, is a major fish hatchery facility. The water supply for the hatchery is derived from a well field located on an alluvial terrace immediately downstream from the dam. Construction of a new navigation lock for the dam will displace the well field which lies in the proposed approach channel for the new lock. A map showing the location of Bonneville Dam on the Columbia River approximately $68 \mathrm{~km}$ east of Portland, Oregon is presented in Figure 1. The downstream terrace area and the location of the hatchery are shown in Figure 2.

Early in the planning phase for the new navigation lock, concerns were raised about meeting the fish hatchery water requirements during and after construction (Cornforth Consultants, Inc., 1987, and U.S. Army Corps of Engineers, 1988b). Not only must a sufficient quantity of water be supplied, but strict temperature and water quality requirements have to be met as well. Fish raised in hatcheries are very susceptible to diseases and the quality of the water supply is essential for successful raising of fish. Water in the temperature range of $8.5-11.5^{\circ} \mathrm{C}$ and free from bacterial, viral and chemical contamination has been found to be optimal (Cornforth Consultants, Inc., 1987). After considering several alternative water supplies, it was decided to relocate the well field towards the north of the proposed approach channel. 
The existing wells pump water from the pre-slide alluvium (PSA) aquifer, a very prolific aquifer that underlies the terrace area and probably extends across the Columbia River as well as down- and upstream (Cornforth Consultants, Inc., 1987). The aquifer predominantly consists of alluvial gravel and is confined by overlying aquitard layers. The removal of part of the overlying deposits that provide protection for the PSA aquifer during the excavation for the downstream approach channel and construction in the terrace area pose a potential threat to the ground water quality of the PSA aquifer and the water supply for the fish hatchery. The flow path for water from the channel into the PSA aquifer and towards the hatchery wells will be shortened. Adverse temperature or water quality effects must be anticipated. Spills of contaminants during construction or lock operation are other potential threats to the hatchery well field. An additional concern is the proximity of the new well field to the Columbia River. Since it is located closer to the river than the old hatchery wells, it might be more directly affected by the annual temperature fluctuations of the river water. Contaminants from the river might move more easily and quickly into the aquifer system and toward the well field.

In the light of these concerns a ground water study was initiated by the U.S. Army Corps of Engineers (USACOE) to assess the water supply from the new well field during and after construction. Pumping test data from the existing fish hatchery wells and water wells in the terrace area as well as water level and temperature data from an automated data acquisition system in the downstream terrace area were analyzed. Together with subsurface data from geotechnical exploration, this information was used to develop an understanding of the ground water system. 
Within the framework of the ground water investigation this study focuses on the analysis of pumping test data and on the development of a three-dimensional computer model for the ground water flow system.

\section{PURPOSE AND SCOPE}

The purpose of this study is to analyze pumping test data from wells in the downstream terrace area at the Bonneville Navigation Lock site in order to develop a three-dimensional ground water flow model for the area. Results from pumping test analysis along with available information from the automated data acquisition system and geotechnical exploration were used to develop the ground water flow model to simulate the ground water system in the area. The model will be used as a management tool during construction and for long term management of the new fish hatchery well field.

The first phase of the study was dedicated to analysis of pumping tests. Data from pumping tests of the fish hatchery wells $\mathrm{H}-3$ and $\mathrm{H}-4$, and of water wells $W W-1794, W W-1800, A-2(W W-1805), A-1(W W-1816)$, and $W W-2030$ (DW-3) were analyzed. Locations of the tested wells and the monitored piezometers are shown on Figure 2. Piezometer HI-1, located across the Columbia River on the Washington Shore (Figure 1) was monitored during this phase of the study to assess the extent of the influence from pumping in the terrace area.

The specific objectives of the first phase of the study were:

1. to determine the magnitude and areal distribution of hydrogeologic parameters of the PSA aquifer;

2. to evaluate the sources of recharge to the PSA aquifer; 
3. to estimate the amount of leakage through the confining layers into the PSA aquifer;

4. to determine the nature and location of hydrogeologic boundaries;

5. to formulate a conceptual model of the ground water flow system that can be used to develop a computer model;

6. to identify the characteristic features of the ground water system that can serve as criteria for the performance of the model.

In the second phase, a three-dimensional computer model for the ground water system was developed. The ground water modeling program HST3D written by Kenneth L. Kipp, Jr. for the U. S. Geological Survey (Kipp, 1987) was chosen as the software most suitable for the study. It allows a fully three-dimensional simulation of ground water flow with associated heat and solute transport using finite-difference techniques.

Within the scope of this study, the specific objectives of the modeling effort were:

1. to discretize the system according to available subsurface data and prior analysis (extent of distinct alluvial units with their hydrogeologic properties, hydrogeologic boundaries, well locations);

2. to calibrate the flow model using the criteria developed in the first phase;

3. to verify the calibration of the flow model by simulating a different set of condition than used for calibration and comparing the results to observed behavior of the ground water system;

4. to identify the hydrogeologic parameters that allow the best match of calculated and observed water levels in the ground water system.

The tremendous amount of information available at the Bonneville Navigation Lock Site provides a unique opportunity to study the interactions between a major river and an adjacent ground water system. In the next step of the ongoing study, 
heat and contaminant transport were included in the model to evaluate the effects of the relocation of the well field and of the proposed downstream approach channel.

\section{SOURCES OF INFORMATION}

The "Final Geologic Report on the Bonneville Project" by Holdredge (1937) and Design Memorandum No. 3, "Geology, Excavation and Foundation", for the Bonneville navigation lock project (USACOE, 1984) were used as references on the geology of the study area.

"Subsurface Material Units Identification and Correlation, Bonneville Navigation Lock", a report to the U. S. Army Corps of Engineers, Portland District by RittenhouseZeman \& Associates (1988) was used for information about the geology and sedimentology of the alluvial deposits in the downstream terrace area.

Drill logs of exploration drill holes, piezometers and water wells drilled for or by the Corps of Engineers on the downstream terrace provided detailed information on specific locations where needed (USACOE, 1984, 1988a and 1989).

Pumping test data were obtained from "Pump Test Data, Bonneville Navigation Lock site, Columbia River, Oregon", a report presented to the U. S. Army Corps of Engineers by Cornforth Consultants, Inc. (1986a). This report along with Design Memorandum No. 9, "Fish Hatchery Well Relocation, Bonneville Navigation Lock, Bonneville Dam, Oregon" (USACOE, 1988b) and the "Fish Hatchery Water Supply, Bonneville Navigation Lock site, Columbia River, Oregon" from Cornforth Consultants, Inc. (1987) were used as references on the available hydrogeologic information. 
During the summer of 1988 piezometer $\mathrm{HI}-1$ located on the Washington shore of the Columbia River (Figure 1) was monitored with an automatic GEOKON CR-10 data-logger.

Current water level and temperature data as well as pumping information contained in the Instrumentation Reports delivered to the U. S. Army Corps of Engineers, Portland District by BCA Geophysics, Inc. (1988) and L.R. Squier Associates, Inc. (1989) were used throughout the study. 


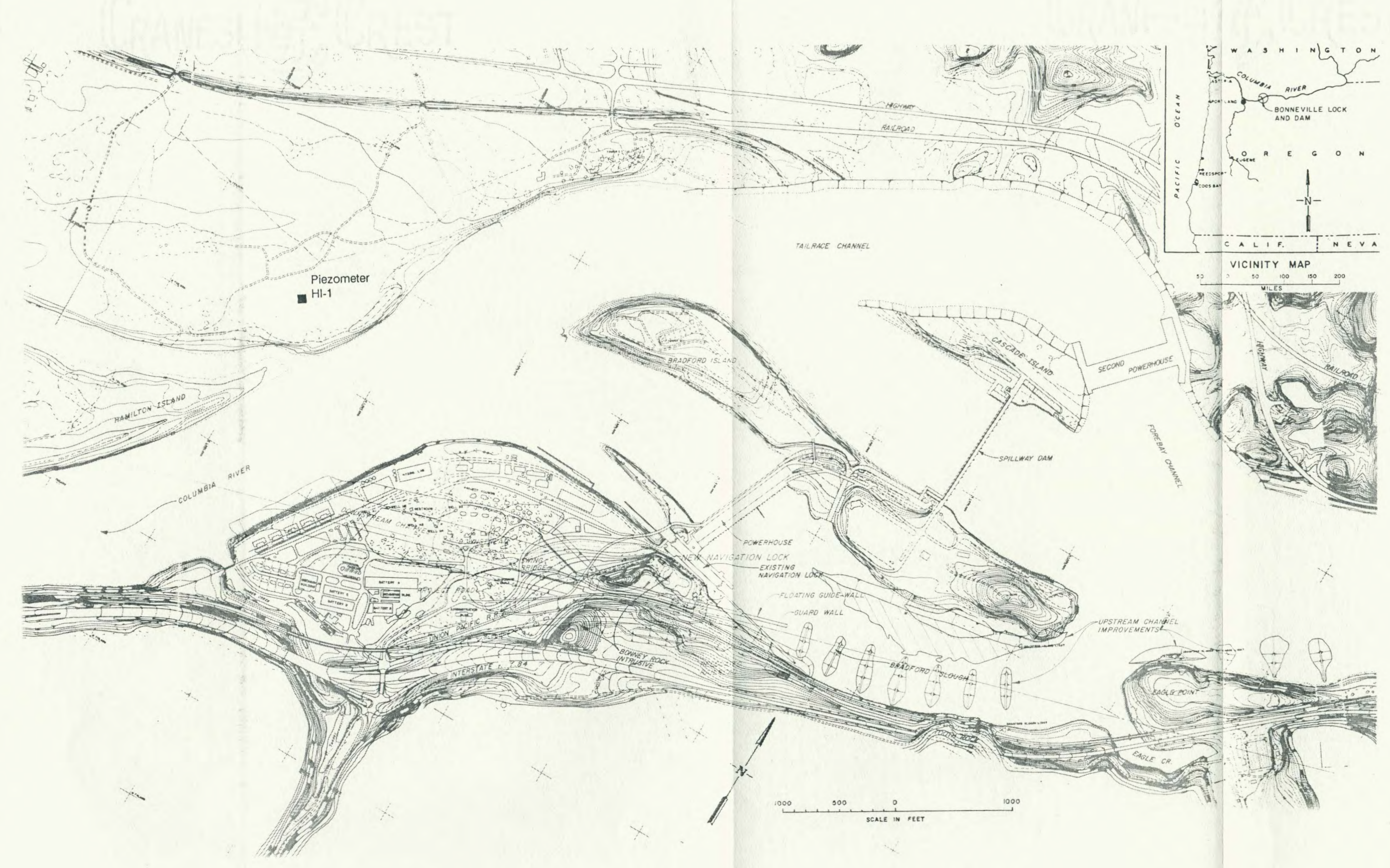

Figure 1. Map of the vicinity of Bonneville Dam on the Columbia River,

Oregon/Washington. Adapted from U.S. Army Corps of Engineers 


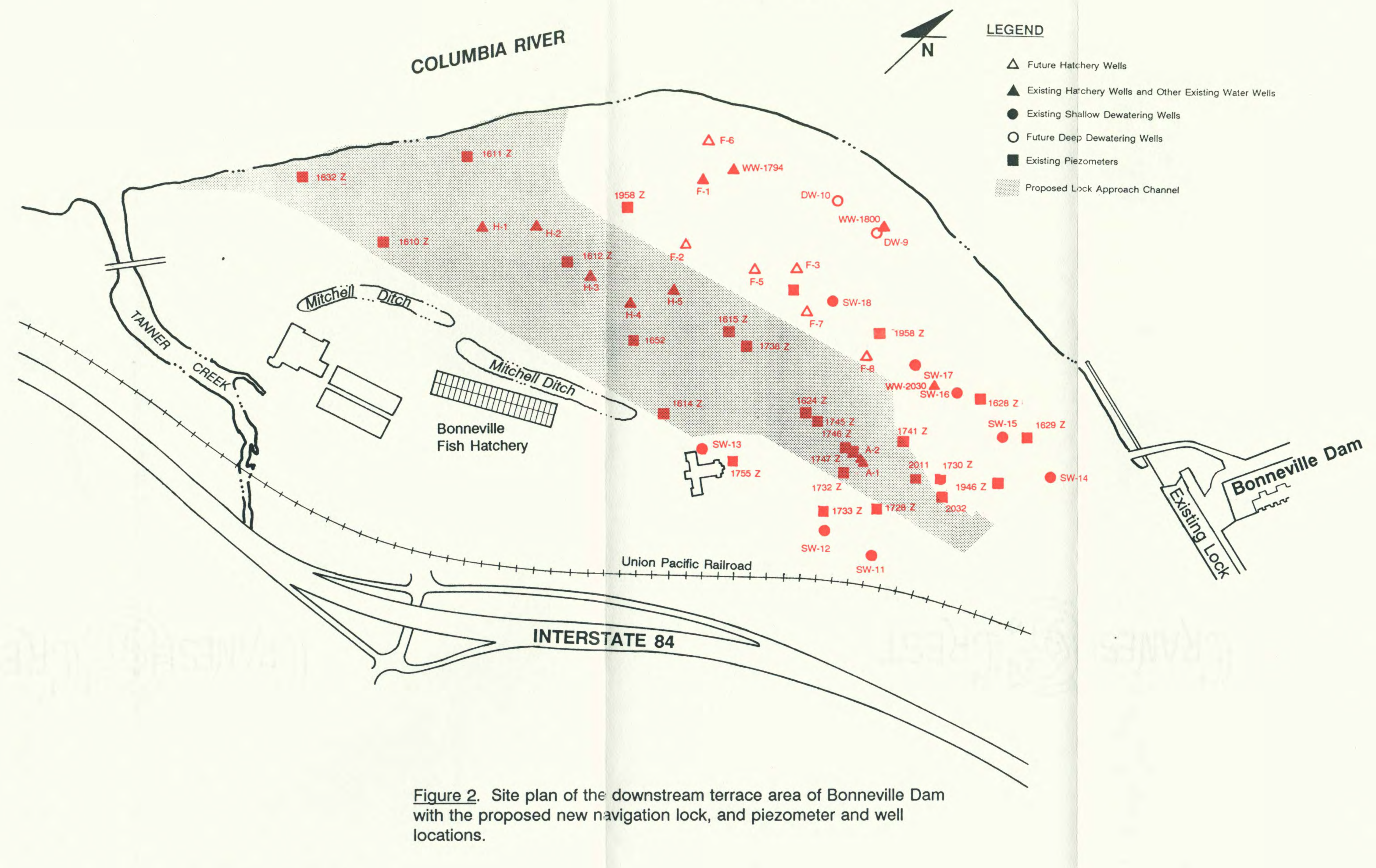




\section{CHAPTER II}

\section{GEOLOGY AND HYDROGEOLOGY}

The first step in examining the ground water system is to look at the regional geology of the area. Then, one needs to look at discrete sedimentary units that make up the aquifer system in the terrace and at the fluvial processes that determined their character and extent.

\section{REGIONAL GEOLOGY}

The regional and site geology was first described by Holdredge (1937). Subsequent research and explorations are summarized by the U.S. Army Corps of Engineers (1984). This review is taken from the information contained in those reports.

The nearly $1000 \mathrm{~m}$ of rock strata exposed in the walls of the Columbia River Gorge above Bonneville Dam record over $\mathbf{4 0}$ million years of volcanism, sedimentation and deformation in the Cascade Range. The gorge also illustrates the erosional power of the Columbia River which was able to cut through the volcanic material that was deposited and later uplifted by tectonic forces. A geologic map of the vicinity of Bonneville Dam is shown in Figure 3.

The oldest exposed rock unit in the Bonneville area is the Eocene Weigle formation which consists of relatively impermeable sedimentary deposits, primarily siltstone and claystone. It underlies the terrace area and most of the valley floor. The 
Eagle Creek Formation overlies the Weigle formation unconformably. It is exposed in the highway cuts along Interstate $\mathbf{8 4}$ where it is composed of mudflow deposits. The Eagle Creek Formation is overlain by the Columbia River Basalt Group which forms the cliffs of the gorge. To the east of the terrace, immediately south of the existing navigation lock, the bedrock units are intruded by a diabase, the Bonney Rock intrusive (BRI), on which the new lock chamber will be founded. Deposits from the Tanner Creek landslide form the southeastern edge of the terrace.

\section{TERRACE DEPOSITS}

The alluvial deposits that make up the downstream terrace consist of a heterogeneous, stratified sequence of alluvial sediment and some reworked landslide debris. The sea level during the Pleistocene was approximately $100 \mathrm{~m}$ lower than at present. Thus the Columbia River was able to erode its channel to a depth of about $80 \mathrm{~m}$ below the present sea level. Floodwater during the Pleistocene Missoula Floods eroded or greatly modified geomorphology of the gorge and the characteristics of the pre-existing deposits. Floodwater at peak flows formed a cascade over the resistant Bonney Rock and eroded a southwest-trending channel into the less resistant bedrock of the Weigle formation downstream of Bonney Rock. The deep river channel was infilled by alluvial deposits and some reworked debris from landslides as the sea level rose after the Pleistocene. Temporary damming by landslides originating from the oversteepened walls of the gorge disrupted and affected the post-Pleistocene fluvial processes of the Columbia River. These landslides blocked the flow of the river forming temporary lakes. The deposits 
forming the landslide dams eroded rapidly when overtopped by the river, causing the release of smaller floods carrying and redepositing landslide debris downstream.

The character of deposits in the downstream terrace reflects the varying fluvial processes of the Columbia River. A representative cross-section through these alluvial deposits is shown in Figure 4. Figure 4 also shows the stratigraphic sequence encountered in the boring for piezometer $\mathrm{HI}-1$ on the Washington Shore of the Columbia River.

\section{Pre-Slide Alluvium (PSA)}

Water cascading over Bonney Rock during Pleistocene floods eroded a channel in the less resistant Weigle formation downstream of Bonney Rock. As the water flow decreased at the end of each flood, a layer of coarse gravel containing abundant cobbles and boulders was deposited. These flood-gravel deposits overlie the Weigle formation in the whole terrace area and are informally named pre-slide alluvium by the Corps of Engineers. The name pre-slide refers to the Bonneville landslide directly upstream of the dam. The clasts are well-rounded and consist of material resistant to weathering, such as local andesite and basalt and exotic rocks derived from the igneous and metamorphic highlands in Idaho. Similar deposits, although somewhat younger, occur across the river in the Second Powerhouse excavation and in the boring for piezometer $\mathrm{HI}-1$ (Figure 1 and Figure 4). On both sides of the river these deposits overlie the Weigle formation. The PSA was divided into three subunits in a report by Rittenhouse-Zeman \& Associates (1988). The lowermost subunit, PSA ${ }_{1}$, consists of coarse gravel with abundant cobble and boulder with minor zones of sand and silt. It occurs primarily in the deeper eroded channel area with its upper surface at approximately $-50 \mathrm{~m}$ elevation. This unit could have 
been deposited by the last major Pleistocene flood. Deposits from earlier floods would have been eroded by subsequent floods.

The PSA, is overlain by a $3-8 \mathrm{~m}$ thick layer of sand, silt and clay of lower hydraulic conductivity, the $\mathrm{PSA}_{2}$ subunit, possibly representing finer materials deposited at the end of the flood and materials deposited by normal river processes. The uppermost subunit, PSA, again consists of coarser materials. However, it is more heterogeneous than the PSA, subunit. It contains rounded gravel with cobble and boulder intermixed with silt and sand lenses. This unit could represent deposits of a late Pleistocene flood that was not large enough to erode previously deposited sediments. Coarse materials deposited by the aggrading Columbia River during the post-Pleistocene sea-level rise could be another mechanism for forming the $\mathrm{PSA}_{3}$ subunit. A slide block and reworked slide debris is present in the upper part of the $\mathrm{PSA}_{3}$ subunit in the northeastern part of the terrace. This subunit marks the earliest documented landslide activity in the Bonneville area.

The upper surface of the PSA is at approximately $-20 \mathrm{~m}$ elevation. In the southwestern part of the terrace the PSA interfingers with alluvial deposits from Tanner Creek (TCA). The PSA extends beyond the terrace area and forms the basal alluvial unit in the gorge (Cornforth Consultants, Inc., 1987)

\section{Mica Sand (MS)}

The mica sand unit overlies the PSA over most of the terrace area. It is $3-13 \mathrm{~m}$ thick and thickens near the landward edge of the terrace along Bonney Rock and the tracks of the Union Pacific Railroad (Figure 2). It was deposited in a lower energy environment than the PSA unit, possibly during the continuing postPleistocene rise in sea level. The mica sand unit consists of fine-grained sand with a 
consistent trace of white mica. The sand is similar to modern day Columbia River sand.

\section{B-Unit (BU)}

The b-unit overlies the MS and contains bluish-gray clay, silt, sand and gravel deposited in a variable energy environment. The b-unit varies greatly both vertically and laterally. In the area south of Mitchell Ditch and west of the fish hatchery (Figure 2), it consists of interbedded gravel and sand layers with clay and silt lenses. In the area between Mitchell Ditch and Bonney Rock, the b-unit can be divided into two subunits (Rittenhouse-Zeman \& Associates, 1988). BC, the silt and clay subunit, consists of a sequence of clay and silt up to $10 \mathrm{~m}$ thick. The BG subunit contains abundant sand and gravel with small amounts of silt and clay similar to the undivided b-unit. The b-unit exhibits some evidence of cut and fill features. The deposits of the b-unit may be the result of cycles of erosion and deposition triggered by landslides temporarily damming the Columbia River and the subsequent breaching of these dams.

\section{River Deposits (RD)}

The uppermost unit in the alluvial sequence consists of recent river deposits. It contains coarse gravel, with cobble, sand and silt. Some slide blocks, slide debris, and reworked slide debris are present in this unit. This unit represents modern day fluvial sediments that were deposited after the occurrence of large landslides. The slide material present in this unit is derived from small local landslides. Fill, consisting of rock and soil materials excavated for construction of railroad, dam, lock, hatchery 
and other facilities, overlies the native materials. The fill material was spread over the terrace for backfilling and landscaping.

\section{HYDROGEOLOGY}

The terrace deposits form a complex system of interconnected aquifers and aquitards. The hydrogeologic information that was available prior to this study is summarized in reports from Cornforth Consultants, Inc. (1987) and the U.S. Army Corps of Engineers (1988a).

The PSA unit is a very productive aquifer. It supplies water to the existing fish hatchery wells and will be the water source for the new well field. It is described as being confined by the overlying layers of mica sand and b-unit. The bedrock below, Bonney Rock to the east and northeast, and landslide deposits and bedrock to the south have very low hydraulic conductivities compared to the terrace deposits. Therefore they act as no-flow boundaries. From pumping tests, transmissivities varying between $2.2^{\star} 10^{-2}$ and $5.0^{\star} 10^{-2} \mathrm{~m}^{2} / \mathrm{s}$ and hydraulic conductivities from $2.6^{\star} 10^{-3}$ to $5.1 * 10^{-3} \mathrm{~m} / \mathrm{s}$ were calculated (Cornforth Consultants, Inc., 1987). The variation in these parameters was interpreted as indicating zones of higher and lower conductivity occurring throughout the aquifer (Cornforth Consultants, Inc., 1987). The location or extent of these zones could not be determined. Analysis for recharge boundaries was inconsistent in identifying the source of recharge for the PSA aquifer (Cornforth Consultants, Inc., 1987).

The finer grained deposits of mica sand and b-unit are believed to confine the PSA aquifer. A pumping test in well A-1 (WW-1816) yielded a value of $7.9^{*} 10^{-4} \mathrm{~m}^{2} / \mathrm{s}$ 
and a hydraulic conductivity of $5.1 * 10^{-5} \mathrm{~m} / \mathrm{s}$ for the mica sand unit (Cornforth Consultants, Inc., 1987). Pumping test data is not available for the b-unit.

The river deposits, the uppermost unit in the alluvial sequence, are heterogeneous and believed to be generally very permeable. From gradation curves, an average conductivity of $5^{*} 10^{-3} \mathrm{~m} / \mathrm{s}$ and maximum values up to $1.8^{*} 10^{-2} \mathrm{~m} / \mathrm{s}$ were calculated (Cornforth Consultants, Inc., 1987). Ground water in this aquifer is described as unconfined and in direct connection to the Columbia River (USACOE, 1988b). 

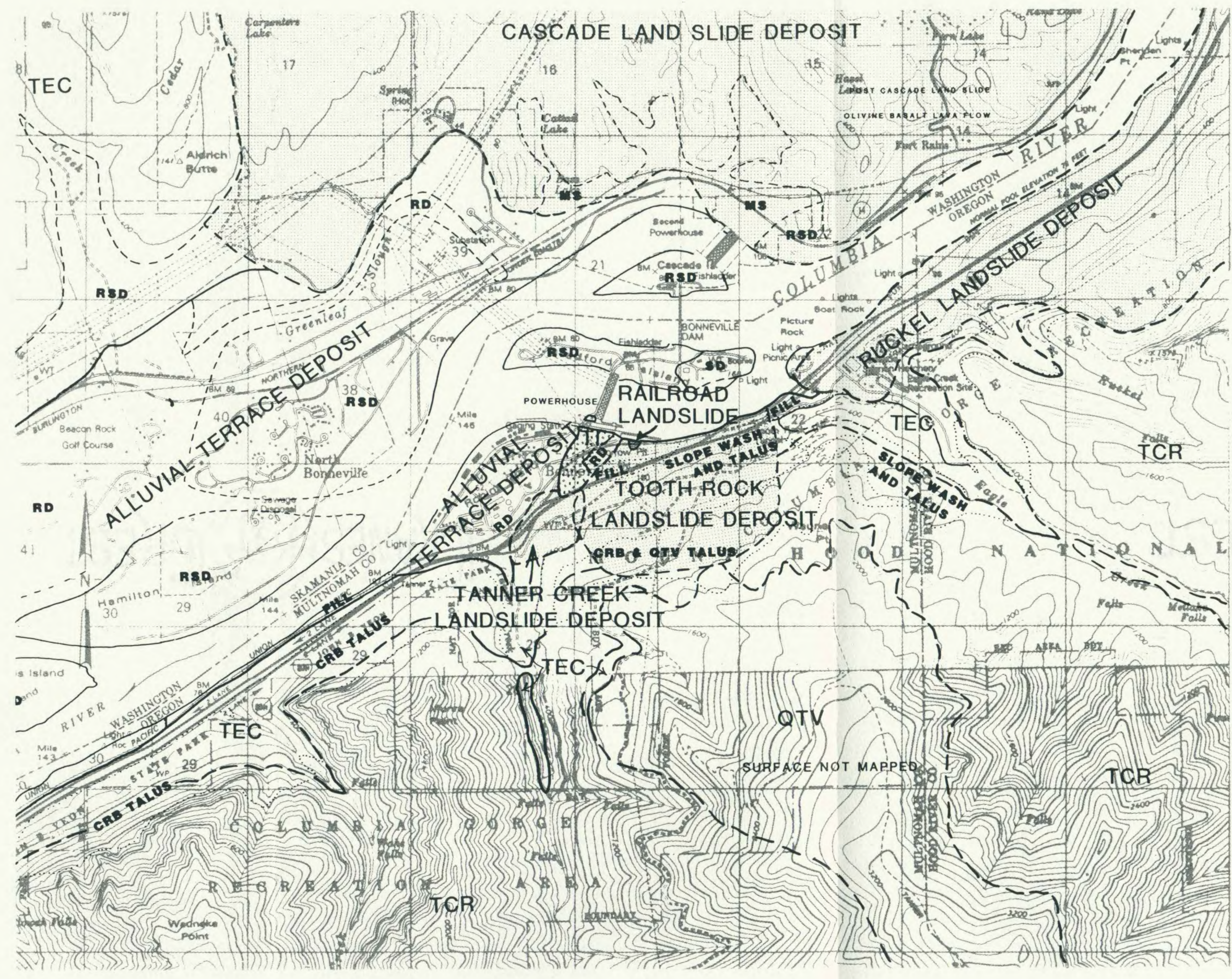

SOIL UNILS - SOIL UNITS ARE DDLLNEATED BY LIGHT LINES

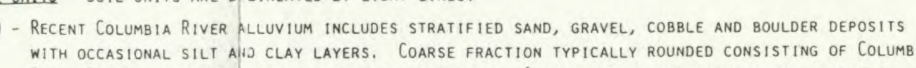

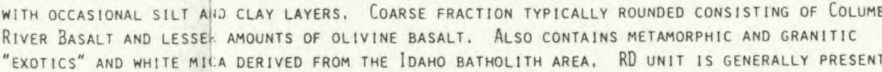

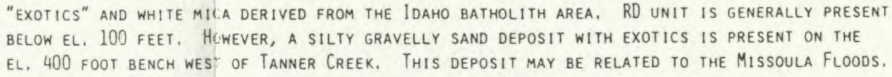

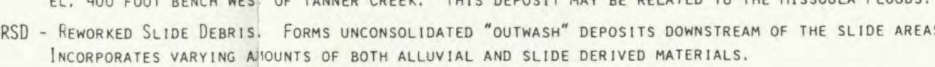

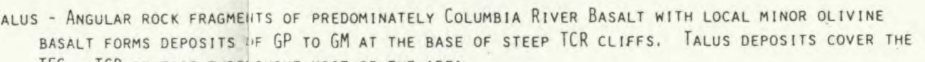

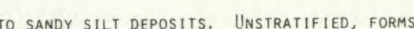

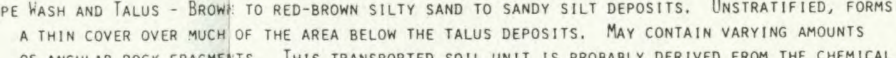

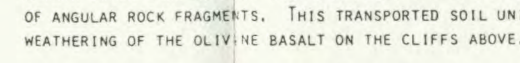

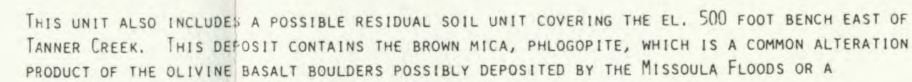

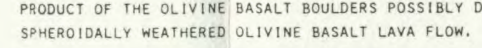

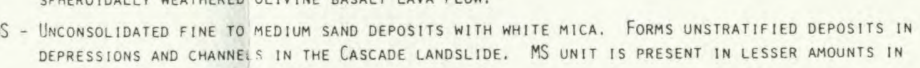
THE TOOTH ROCK LANDSLDE AREA

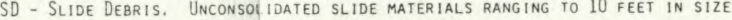

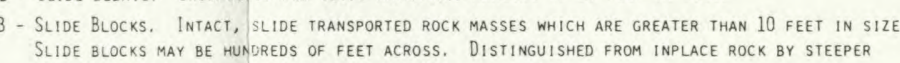

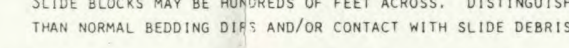

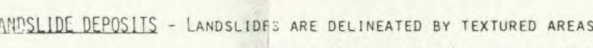

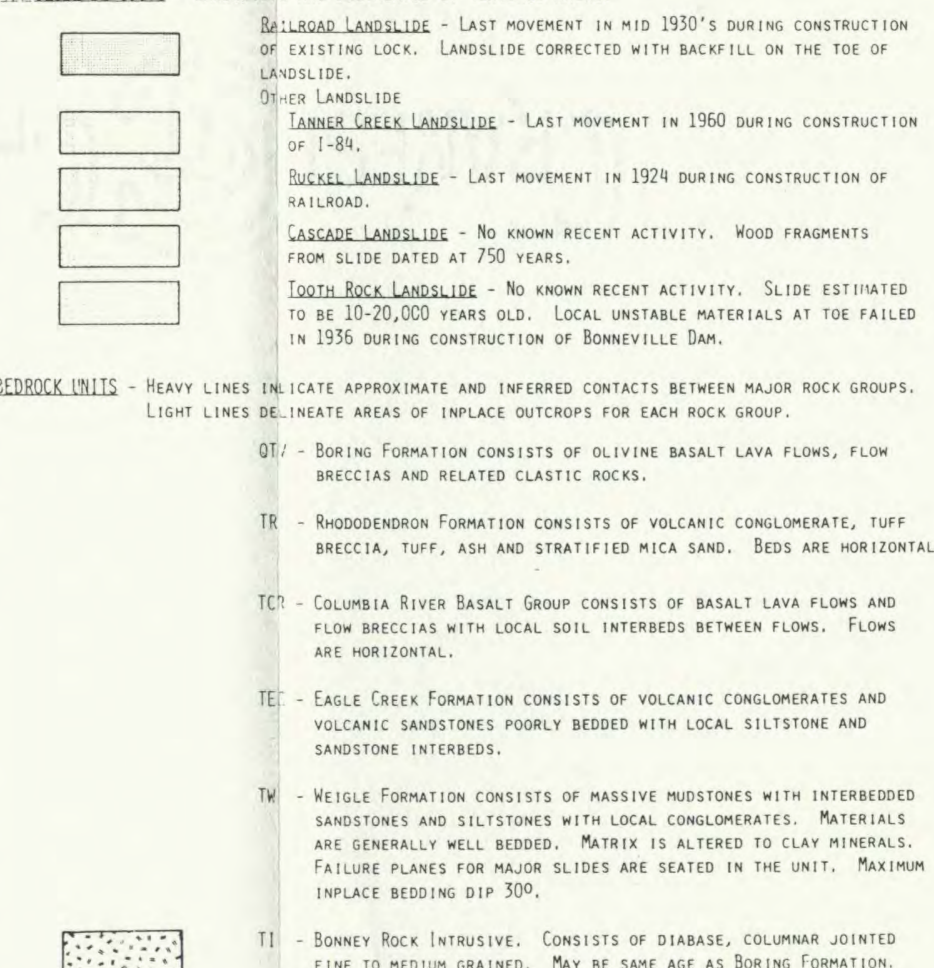

Figure 3. Geologic map of the vicinity of Bonneville Dam. Adapted from U.S. Army Corps of Engineers (1984). 


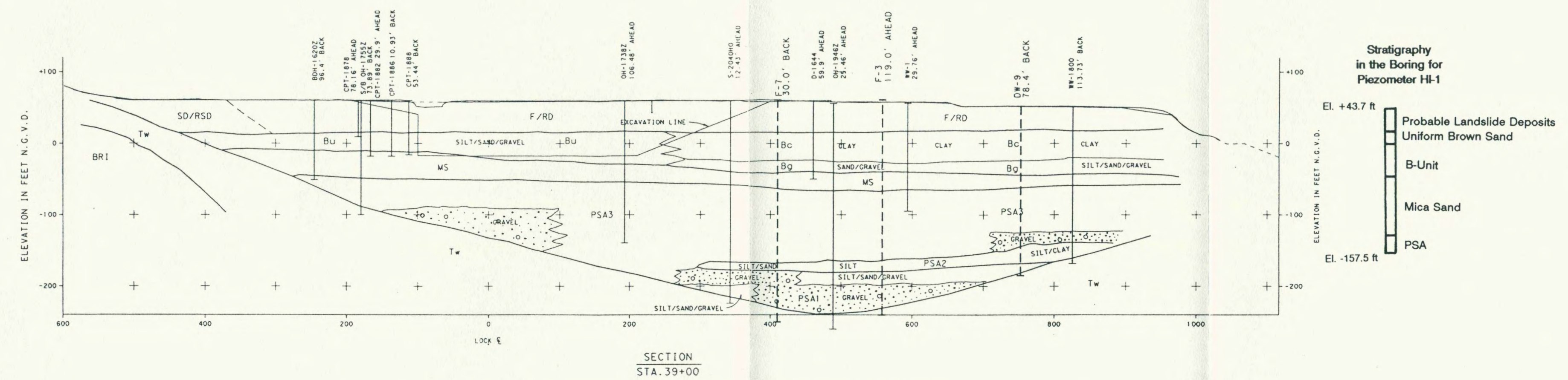

Figure 4. Representative geologic cross-section of the downstream terrace area. Adapted from U.S. Army Corps of Engineers (1990). 


\section{CHAPTER III}

\section{PUMPING TEST ANALYSIS}

\section{SOURCES OF RECHARGE FOR THE PSA AQUIFER}

Plots of drawdown versus time for the pumping tests in the PSA aquifer show a stabilization of the piezometric surface of the aquifer after about 200 minutes of pumping (Figure 5). At that time, the system reaches an equilibrium between discharge through pumping and recharge to the aquifer. For the selection of an appropriate method for the analysis of pumping tests in the PSA aquifer, it is essential to evaluate where the recharge to the aquifer comes from. Does the aquifer receive recharge directly from the Columbia River or is recharge derived primarily from leakage through the confining layers? Different approaches were used to answer this question.

\section{Method Of Images}

A hydrogeologic boundary that is an abrupt discontinuity such as a stream penetrating a confined aquifer (Figure 6a) can be represented by a hypothetical image well which is easier to describe analytically. With this approach, the real bounded system with the real well and the recharge boundary is represented for the purposes of analysis by an imaginary system of infinite areal extent (Figure 6b). In this system there are two wells pumping, the real well on the left and the image well on the right. The image well in this case is an injection well, injecting water at a rate, 
$Q$, equal to the pumping rate of the real well. It is located at an equal distance, $x$, on the opposite side of the boundary. According to the principle of superposition (Bear, 1979), the cone of depression from the pumping well and the cone of build-up from the imaginary injection well can be added to give the combined drawdown of the twowell system. It becomes apparent that this pumping scenario creates a constant head boundary at the exact location of the real constant head boundary (Figure 6c).

Based on the image well concept, Heath and Trainer (1968) describe a method to determine the position of a constant head boundary based on the Theis Method. A logarithmic plot of drawdown versus time from a piezometer monitoring a pumping test is matched with the Theis curve. From the early part of the drawdown data when observed drawdown completely matches with the Theis curve, the time, $t_{r}$, at which a certain amount of drawdown, s, occurs, is determined. From the later part of the drawdown data, when observed drawdown deviates from the Theis curve as a result of recharge from the constant head boundary, the time, $t_{i}$, at which the deviation from the Theis curve is equal to the drawdown from the real well, $s$, at time $t_{r}$, is determined. These two times along with the distance of the real well to the piezometer are then used to find the distance from the piezometer to the image well:

$$
r_{i}=r_{r} *\left(t_{i} / t_{r}\right)^{1 / 2}
$$

where distance from piezometer to image well

$r_{r} \quad$ distance from piezometer to real well

$t_{i} \quad$ time at which deviation from Theis curve attributed to image well reaches a certain amount, $s$

$t_{r} \quad$ time at which drawdown from the real well is a certain amount, $s$ 
Figure 7 shows an example for the calculation. This procedure was applied to five piezometers monitoring the pumping test in $\mathrm{H}-4$. If the distance to the image well from several piezometers is calculated, the location of the image well and the constant head boundary, if one is present, can be determined. Calculated distances to the image wells and distances from the piezometers to the pumping well are listed in Table I. Figure 8 shows circles around the piezometers representing the distance to the hypothetical recharging image well. If a linear constant head boundary represented by the image well were present, these circles would intersect at one point, the location of the image well. They clearly do not intersect at one point. Instead, calculated distances to the image well appear to be related to radial distance between the piezometers and the pumping well (Table I). This could indicate that recharge occurs over a large area by vertical leakage through the confining layers rather than through a constant head boundary such as the Columbia River. Close to the pumping well, drawdown is large, and so is recharge by leakage induced by the hydraulic gradient between aquifer and overlying deposits. Hypothetical image wells representing recharge appear to be close. At larger distances from the pumping well, drawdown is lower and so is the induced leakage. The image well in this case will appear farther away.

\section{Observations in Piezometer $\mathrm{Hl}-1$}

Monitoring the water level in piezometer $\mathrm{HI}-1$ on the Washington shore of the Columbia River (Figure 1) added information about the source of recharge to the PSA aquifer. $\mathrm{HI}-1$ is located $1070 \mathrm{~m}$ from the fish hatchery well field and $100 \mathrm{~m}$ north of the river shore. During the summer of 1988 it was monitored at 15-minute-intervals with a GEOKON CR-10 automatic data logger. Figure 9 shows a record of water 
levels over a 12 day period. The water level in the piezometer is generally $0.5 \mathrm{~m}$ above the Columbia River water level and closely follows stage changes. River efficiency, the percentage of the magnitude of the change in river stage that is reflected in the piezometer, is approximately $30 \%$.

During the period shown in Figure 9, one of the fish hatchery wells was shut off, lowering the total pumping rate in the hatchery well field by $0.22 \mathrm{~m}^{3} / \mathrm{s}$. Figure 10 shows this event in detail. The effect of the change in pumping rate on the water level in the piezometer is obscured by a rise in river stage which occurred at the same time. To correct the water level in the piezometer for the effect of the change in river stage, a filtering procedure was applied. The filtering procedure was designed to eliminate the effect of the stage change, thus allowing the response of the water level in the piezometer to the change in pumping rate in the hatchery well field to be determined. Filtering has to account for the time delay of the response to stage changes and for the river efficiency, the amount of change in the water level in the wells as the result of a given change in river stage. It also needs to account for the dampening effect of the aquifer system. A large change in the river stage over a short time might show little effect on the aquifer, whereas a change of similar magnitude but occurring over a longer time would have a much stronger effect. Figure 11 illustrates this effect.

The filter used is a "leaky integrator" (Johnson, 1973), which takes all three effects into account:

$$
Z(I)=(1-E) * Z(I-1)+(E * Y(I))
$$


where

$$
\begin{array}{ll}
Z(I) & \text { filtered river stage } \\
Z(I-1) & \text { last filtered river stage } \\
Y(I) & \text { unfiltered river stage } \\
E & \text { filter coefficient }
\end{array}
$$

The filter coefficient can be in the range from zero to one, where zero is equivalent to total filtering (no data input), and one means no filtering (no past history kept). A small value for $E$ results in strong filtering, large values for $E$ produce less filtering. The resulting values were then multiplied with a factor to account for the river efficiency. Values for the filter coefficient and the multiplication factor for the piezometer depend on distance from the river, screened interval and local properties of aquifer materials. The optimum values were determined using periods in which changes in the pumping rate did not occur. During these periods water level in the aquifer is only influenced by the river stage changes. Different combinations of the values for the filter coefficient and the multiplication factor were tried out and the values giving the non-fluctuating, stable water level in the aquifer were determined.

The FORTRAN program WLPROCS2 (Johnson, 1988) was used to perform the filtering. Figure 12 shows the Columbia River stage and the filtered river stage along with observed and corrected water level in the piezometer. Figure 13 shows a logarithmic plot of the recovery of the water level in $\mathrm{HI}-1$ after correction for the stage fluctuation. Decrease of the pumping rate by $0.22 \mathrm{~m}^{3} / \mathrm{s}$ results in a rise of the water level of $0.3 \mathrm{~m}$ with the response starting about 30 minutes after pump shut-off. A total of five changes in the pumping rate of the fish hatchery well field were documented during the monitored period. In all cases, a response on the Washington shore was observed, clearly indicating that the influence from pumping in the downstream terrace area extends well beyond the Columbia River. 


\section{Response of the Shallow Aquifer to Pumping}

A response of the shallow aquifer (river deposits) to pumping in the PSA aquifer has been reported (USACOE, 1988b). This indicates that the aquifers are hydraulically interconnected and that some leakage through the confining layers must occur.

To further evaluate whether and to what extent pumping in the PSA aquifer affects the shallow aquifer, the effect of two changes in the pumping rate from the hatchery well field that occurred during August and September 1989 were examined in detail. It is difficult to determine if the shallow aquifer responds to pumping in the PSA aquifer because the relatively small changes caused by pumping are easily obscured by much larger water level fluctuations due to river stage changes. Water levels in shallow piezometers before and after the changes in the pumping rate were evaluated. To avoid interference from river stage fluctuations, the water levels were compared at times where the water level elevation in the river was the same and no fluctuations occurred. By doing this the difference in water level in the shallow piezometers can be attributed to the changed pumping rate from the well field. The water levels in the piezometers are summarized in Table II. The shallow piezometers clearly show a response to the changed pumping rate. Changes in the pumping rate of 0.22 and $0.24 \mathrm{~m}^{3} / \mathrm{sec}$ result in a change in water levels in shallow piezometers on the order of about $0.4 \mathrm{~m}$. This indicates that some interaction between the two aquifers must occur. 


\section{Discussion}

It was not possible to identify the Columbia River as a recharge boundary for the PSA aquifer with the image well method. Instead recharge appears to occur over a large area. A response to changes in pumping in the hatchery well field was observed in piezometer $\mathrm{HI}-1$ on the Washington shore of the Columbia River, indicating that the cone of depression from pumping in the hatchery well field extends beyond the Columbia River. A response in the shallow aquifer to pumping in the PSA aquifer was documented.

Two different possible scenarios for a river/aquifer system are sketched in Figure 14. Figure 14a shows a confined aquifer in direct connection to the river. Drawdown does not extend beyond the river and is clearly smaller in the vicinity of the recharging river than in areas farther away from the river. Figure $14 b$ shows an aquifer that is separated from the river by an aquitard layer that extends beneath the river. Here the cone of depression can extend beyond the river and drawdown distribution is more uniform. The observations described above appear to indicate that our system resembles more closely the scenario in Figure 14b. It appears that the major part of the recharge to the PSA aquifer is derived from leakage through the confining aquitard layers. An aquitard layer appears to extend continuously beneath the Columbia River.

Based on the foregoing, the Hantush-Jacob Method for leaky aquifers was chosen as the primary analytical technique for pumping test analysis. This method is designed to account for vertical leakage through confining layers. 


\section{METHODS OF PUMPING TEST ANALYSIS}

Hantush and Jacob (1955) developed an analytical solution for non-steady radial flow to a well in an infinite leaky aquifer. It describes the variation with time of the drawdown induced by a well steadily discharging from an infinite leaky aquifer. A schematic diagram of a leaky aquifer system is shown in Figure 15. The solution can be written in terms of two parameters, the dimensionless parameter $\mathrm{r} / \mathrm{B}$ defined by

$$
r / B=r /\left(T * b^{\prime} / K^{\prime}\right)^{1 / 2}
$$

and the parameter $u$

$$
u=\left(r^{2} * S\right) /(4 * T * t)
$$

where $\quad r \quad$ distance from piezometer to pumping well
S aquifer storativity
T aquifer transmissivity
$t$ time since pumping started
b' thickness of the aquitard
K' vertical hydraulic conductivity of the aquitard.

The solution is

$$
h_{0}-h=Q * W(u, r / B) /(4 * \pi * T)
$$

where

$\begin{array}{ll}h_{0} & \text { initial water level } \\ h & \text { water level during pumping } \\ Q & \text { pumping rate } \\ T & \text { transmissivity of the aquifer }\end{array}$




$$
W(u, r / B) \quad \text { leaky well function. }
$$

The leaky well function, W(u,r/B), was tabulated by Hantush (1956) and a plot of this function against $1 / u$ gives a set of type curves for different values of $r / B$ that is used for matching the pumping test data. The $W(u, r / B)$ type curves are shown in Figure 16. The solution is based on the following assumptions:

1. flow through the aquitard is vertical, flow in the aquifer is horizontal,

2. the aquifer is infinite in extent and confined,

3. the layers are uniform in thickness,

4. discharge is derived from a reduction of storage in the aquifer and from leakage through the aquitard,

5. leakage is proportional to drawdown in the aquifer at any point,

6. the aquitard does not store water,

7. drawdown in the unpumped aquifer does not occur.

The Hantush-Jacob Method was applied by manually matching pumping test data to the set of type curves (Figure 17). In addition, the BASIC program TSSLEAK (van der Heijde, 1985) was used. This program directly calculates aquifer parameters using a least square fitting procedure to find the best match between data and type curves.

The Theis Method (Theis, 1935) and the Jacob-Semilog Method (Cooper and Jacob, 1946) were used for an additional verification of the results. Since leakage is not considered by these two methods, only data from the early stage of the pumping tests, when the effects of recharge are negligible, were used to calculate values for aquifer transmissivity and storativity. Theis developed an equation describing drawdown in a confined aquifer with a well discharging at a constant rate. A plot of 
the well function, $W(u)$, against $1 / u$ (Figure 18 ) is matched to the pumping test data and transmissivity and storativity can be determined. An example for the determination of aquifer parameters with the Theis Method is shown in Figure 19.

Cooper and Jacob (1946) pointed out that for small values of $u$ the well function can be approximated by a simpler logarithmic term, and developed a technique, the Jacob-Semilog Method, where pumping test data is plotted on a semilogarithmic scale. For values of $u<0.05$ the data points will plot as a straight line. Transmissivity is calculated from the slope of the line and storativity can be determined from the intercept of the extended straight line at zero time. Figure 20 shows how aquifer parameters are determined with this method.

\section{PUMPING TESTS}

\section{Fish Hatchery Wells $\mathrm{H}-3$ And H-4 (PSA Aquifer)}

Pumping tests in $\mathrm{H}-3$ and $\mathrm{H}-4$ were conducted on August 12 and August 6, 1986 , respectively. The wells were pumped at rates of $0.281 \mathrm{~m}^{3} / \mathrm{s}$ and $0.284 \mathrm{~m}^{3} / \mathrm{s}$ from the PSA aquifer. Five piezometers and the pumping well were monitored during the test in $\mathrm{H}-3$. During the test in $\mathrm{H}-4$ nine piezometers were monitored. Information about the pumping wells and the piezometers is included in Appendix A. The locations of wells and piezometers are shown in Figure 2. Columbia River stage was almost stable during the tests (Figure 21) and did not affect the measured drawdowns. Results from the different analytical techniques are listed in Table III. They show close agreement among the different methods. Differences are a result of the different assumptions on which the various methods are based. An average value from the different methods, or the value from the method that, based on the 
assumptions of individual methods, seemed most appropriate for a particular piezometer, was chosen as representative for that piezometer. These values are presented in Table IV.

\section{A-2 (PSA Aquifer)}

The pumping test in well A-2 (MW-1816) was conducted on July 31 and August 1,1986 . Test well A-2 was pumped at a constant rate of $0.126 \mathrm{~m}^{3} / \mathrm{s}$ from the PSA aquifer. The pumping well and twenty-four piezometers at different locations and screened at different elevations were monitored during the test. Figure 2 shows the locations of pumping well and piezometers, information about well A-2 and the piezometers is included in Appendix A.

About 400 minutes after pumping started, a fluctuation in the river stage of $1.3 \mathrm{~m}$ affected the water levels in the wells monitored. Figure 22 shows water levels in the river during the test, and Figure 23 shows a time-drawdown plot for one of the piezometers (1746-Z1) showing the effect of the fluctuation of the river stage on the piezometric surface of the PSA aquifer. The water-level rise in the river influences the piezometric surface of the aquifer and obscures the drawdown from the pumping test. Since good quality data from the later part of the pumping test are crucial to determine vertical hydraulic conductivities of the confining layers and leakage rates through these layers, the water levels in the piezometer were corrected for the influence of fluctuations in the river stage.

The filtering procedure described in the section on observations in piezometer $\mathrm{HI}-1$ was used to correct water levels in the pumping well and piezometers for the river stage fluctuation. It was found that the piezometric surface of the PSA aquifer reacts almost instantaneously to river fluctuations. The river efficiency for different 
piezometers varies between 40 and $60 \%$. Figure 24 shows the correction process for piezometer $1746-Z 1$ as an example. Uncorrected water level, filtered river stage and the corrected water level (the filtered river stage subtracted from the uncorrected water level) are plotted. The corrected time-drawdown data were plotted on a logarithmic scale and used for further analysis. Figure 25 shows an example of the corrected time-drawdown data. This procedure allowed use of information in the later phase of the pumping test. Results of the pumping test analysis are presented in Table IV.

\section{Other Pumping Tests in the PSA Aquifer}

During the geotechnical exploration for the new hatchery well field pumping tests were performed in wells WW-1794, WW-1800, WW-2030 (DW-3) in October 1988. Figure 2 shows the locations of the wells. WW-1800 and WW-2030 lie in the area where a slide block and reworked slide debris are embedded in the PSA aquifer. Pumping rates were $2.52^{\star} 10^{-2} \mathrm{~m}^{3} / \mathrm{s}$ for $W W-1800,2.78^{*} 10^{-2} \mathrm{~m}^{3} / \mathrm{s}$ for $\mathrm{WW}-1794$, and $1.26^{\star} 10^{-2} \mathrm{~m}^{3} / \mathrm{s}$ for $\mathrm{WW}-2030$. Water levels were measured in the wells, and piezometers in the terrace area were monitored by the automatic data acquisition system on the site (BCA Geophysics, Inc., 1988). Only water levels in the test wells were used for analysis because the low pumping rates affected the aquifer only in the close vicinity of the pumping wells. Measurements of water levels in the test wells were done with pressure transducers that did not function properly while the pumps were operating due to vibrations from the pump. Therefore, the recovery of the piezometric surface after pump shut-off was used to determine aquifer transmissivity. The Jacob-Semilog Method was used. Calculated transmissivity values are 
$4.03^{\star} 10^{-3} \mathrm{~m}^{2} / \mathrm{s}$ for $W W-1800,2.73^{\star} 10^{-4} \mathrm{~m}^{2} / \mathrm{s}$ for $\mathrm{W} W-2030$ and $2.45^{\star} 10^{-2} \mathrm{~m}^{2} / \mathrm{s}$ for WW-1794.

In November 1988 pumping tests were performed in well F-1 (WW-2033) by Robinson \& Noble, Inc. (1988). A value for the aquifer transmissivity of $1.3^{*} 10^{-2} \mathrm{~m}^{2} / \mathrm{s}$ was calculated (Robinson \& Noble, Inc., 1988).

From the transmissivities and PSA aquifer thicknesses at the well locations (Rittenhouse-Zeman \& Associates, 1988) hydraulic conductivities of $1.47^{\star} 10^{-4} \mathrm{~m} / \mathrm{s}$ for $W W-1800,9.8^{\star} 10^{-4} \mathrm{~m} / \mathrm{s}$ for $W W-1794$, and $7.16^{\star} 10^{-6} \mathrm{~m} / \mathrm{s}$ for $W W-2030$ were calculated. The low transmissivity and conductivity values in WW-1800 and WW-2030 could be a result of the slide block and reworked slide debris in that area. WW-1794 appear not to be affected by the slide block. Hydraulic conductivity for well F-1 was not calculated according to a report from Robinson \& Noble, Inc. (1988).

\section{A-1 (Mica Sand)}

On August 4 through August 5, 1986 two pumping tests were performed in well A-1 (MW-1816) which was screened in the upper part of the mica sand unit. Test 1 was terminated due to pump failure after 4 hours, Test 2 ran for 26 hours. Pumping rates were $6.30^{\star} 10^{-3} \mathrm{~m}^{3} / \mathrm{s}$ and $7.26^{\star} 10^{-3} \mathrm{~m}^{3} / \mathrm{s}$ respectively. Twenty-four piezometers and the pumping well were monitored during Test 1 , and 10 piezometers in addition to the pumping well were monitored during Test 2. Information about the pumping well and the piezometers is included in Appendix A. Locations of well A-1 and the monitored piezometers are shown in Figure 2. In both tests, the water level in well A-1 stabilized after 10 minutes. During Test 1 the river stage was stable while Test 2 was affected by a river stage fluctuation of about $1.2 \mathrm{~m}$. The water levels in A-1 during the pumping tests and the Columbia River stage during the tests are shown in 
Figures 26 and 27. A response to pumping could not be observed in the monitored piezometers. Even piezometer $1747-Z 1$, only $4 \mathrm{~m}$ away from $\mathrm{A}-1$, shows no drawdown. The radius of the cone of depression is very small. Another possible reason for the lack of drawdown beyond the pumping well is that the piezometers usually monitor a wide zone of the aquifer while A-1 is only screened in the small interval between elevation $-4.9 \mathrm{~m}$ and $-18.4 \mathrm{~m}$ (Appendix A).

Since no drawdown data from piezometers outside the pumping well are available only the Jacob-Semilog Method was used for analysis. Transmissivity values calculated from drawdown in the pumping well from Test 1 and Test 2 are $4.75^{*} 10^{-4} \mathrm{~m}^{2} / \mathrm{s}$ and $6.18^{*} 10^{-4} \mathrm{~m}^{2} / \mathrm{s}$ respectively. The value from Test 1 was chosen as more accurate because the system was unaffected by prior pumping and river level fluctuations. The thickness of the mica sand unit where A-1 is located is $15 \mathrm{~m}$. That gives an estimate of hydraulic conductivity of $3.2^{*} 10^{-5} \mathrm{~m} / \mathrm{s}$ for the mica sand unit. No storativity value can be calculated from drawdown in the pumping well.

\section{VERTICAL LEAKAGE}

Different approaches were used to quantify the vertical hydraulic conductivity of the confining layers b-unit and mica sand. This parameter controls how much water can leak into the PSA aquifer from the overlying units which are in direct hydraulic connection to the Columbia River. It is also critical in evaluating the potential effects of the new approach channel on the ground water. Vertical hydraulic conductivity determines the rate at which water from the approach channel will enter the aquifer. The quantity of water from the approach channel moving into the aquifer and the velocity at which it travels through the confining layers are two factors that 
control filtering and temperature buffering capacity of the system and possible adverse affects on the PSA aquifer and the hatchery well field.

Methods that were used to determine the vertical hydraulic conductivity are the Hantush-Jacob Method for leaky aquifers (Hantush and Jacob, 1955) and the Ratio Method developed by Neuman and Witherspoon (1972). Falling-head permeability tests on two samples from the mica sand unit were done by the Corps of Engineers (USACOE, 1990).

The Hantush-Jacob Method was described earlier. It is the standard technique for the evaluation of leaky aquifer systems. Limitations of the method are that no storage in the aquitard as well as no drawdown in the unconfined upper aquifer are assumed. Furthermore, b-unit and mica sand unit have to be considered as one uniform aquitard layer. The advantage of the method is that the value for the vertical hydraulic conductivity can be readily determined from the match between pumping test data type curves. Calculated values for the vertical hydraulic conductivity of the confining layers range from $8.5^{\star} 10^{-7}$ to $1.5^{\star} 10^{-4} \mathrm{~m} / \mathrm{s}$; results for 14 piezometers are listed in Table V. It appears that for piezometers far away from the pumping well small values are obtained, while piezometers close to the pumping well yield higher values. The reason for this could be that the small drawdown at large distances from the pumped well does not induce much leakage in the short time monitored during the pumping tests. Thus vertical hydraulic conductivity at large distances from the pumped well could be underestimated by this method. Neuman and Witherspoon (1969a, 1969b and 1972) discuss the validity of Hantush-Jacob Method to evaluate the hydraulic conductivity of aquitards. They find that the extent to which leakage can affect the behavior of the drawdown in an aquifer is a function 
of the radial distance from the pumping well. They arrive at the conclusion that errors introduced by the Hantush-Jacob Method will be small if the data are collected close to the pumping well, but may become significant when the observation well is placed too far away. Based on the foregoing, the values for vertical hydraulic conductivity of the aquitard layers obtained for piezometers close to the pumping wells appear to be more reliable.

Neuman and Witherspoon (1972) present a more sophisticated method for the determination of aquitard vertical hydraulic conductivity. They use drawdown in both the aquifer and in the aquitard. The ratio of the drawdown in the aquitard to that measured in the aquifer at the same time and the same radial distance from the pumping well is used to evaluate the properties of the aquitard. This method does not have the limitations of the Hantush-Jacob Method. However, it requires detailed drawdown data in the aquitard and a value for the specific storage of the aquitard which has to be determined in consolidation tests of sediment samples. Because of the limitations of the available data this method was only applied to piezometer 1738 . The shallow piezometer, $1738-\mathrm{Z2}$, is screened in the mica sand unit, $5.5 \mathrm{~m}$ above the PSA aquifer. The deeper piezometer, 1738-Z1, is screened in the PSA aquifer. A specific storage of $7.9^{*} 10^{-4} \mathrm{~m}^{-1}$ was calculated from consolidation tests on mica sand samples from drill holes 1644 and 1652 (USACOE, 1984) which are located in the vicinity of piezometer 1738 (Figure 2). Time-drawdown data from pumping test A-2 were used. A value of $2.4^{*} 10^{-6} \mathrm{~m} / \mathrm{s}$ for the vertical hydraulic conductivity of the mica sand was calculated. The calculations are included in Appendix B. 
Two falling-head permeability tests on undisturbed samples from the mica sand were done by the Corps of Engineers (USACOE, 1990). Samples from drill holes 2011 and 2032 gave values of $1 * 10^{-6}$ and $1 * 10^{-5} \mathrm{~m} / \mathrm{s}$ respectively.

The values for the vertical hydraulic conductivity of the aquitard obtained for different locations and from the different methods vary from $1 * 10^{-6}$ to $1 * 10^{-4} \mathrm{~m} / \mathrm{s}$. This appears to reflect the heterogeneity of the aquitard layers. To some degree the different approaches and assumptions of individual methods could contribute to the variations in the results. It is important to remember that for the Hantush-Jacob Method mica sand and b-unit are considered as one aquitard layer, while the Ratio Method and the laboratory test results are specifically for the mica sand.

\section{BOUNDARIES}

The question whether the Columbia River acts as a recharge boundary for the PSA aquifer was discussed earlier. Although the Columbia River is the major water source for the aquifer system, it could not be identified as a recharge boundary for the PSA aquifer. It appears that recharge to the PSA aquifer is primarily from vertical leakage through the overlying confining layers over a large area. The shallow aquifer and the confining layers for the PSA aquifer appear to be in direct hydraulic connection with the river.

Piezometers close to the bedrock slopes in the south of the terrace area and close to Bonney Rock in the east of the terrace generally show a larger drawdown than piezometers close to the Columbia River. Bedrock slopes and Bonney Rock act as impermeable boundaries relative to the more permeable alluvial terrace deposits. 
The bedrock of the Weigle formation underlying the terrace area is also considered as an impermeable boundary.

\section{SUMMARY OF HYDROGEOLOGIC PARAMETERS FOR THE ALLUVIAL UNITS}

Values for the hydrogeologic parameters transmissivity, conductivity and storativity of the PSA aquifer found from analysis of different pumping tests are compiled in Table IV. Aquifer transmissivity ranges from $2.73^{*} 10^{-4}$ to $3.31 * 10^{-2} \mathrm{~m}^{2} / \mathrm{s}$, and hydraulic conductivities calculated from the transmissivity and PSA unit thicknesses (Rittenhouse-Zeman \& Associates, 1988) range from $7.16^{\star} 10^{-6}$ to $2.79^{\star} 10^{-3} \mathrm{~m} / \mathrm{s}$. Storativity varies between $3^{*} 10^{-5}$ and $7 * 10^{-3}$. The variations appear to reflect the heterogeneity of the aquifer. The very low values found for $W W-1800$ and WW-2030 appear to be related to the presence of a slide block and reworked slide debris embedded in the PSA aquifer.

One of the objectives of the pumping test analysis was to describe the areal distribution of transmissivity and conductivity in the PSA aquifer. Using the results from pumping wells and piezometers, maps of the distribution of these parameters were drawn (Figures 28 and 29). The contours were generated with a graphics program using a kriging procedure. The parameters determined for the piezometers were assumed to be representative for the vicinity of the respective piezometer. A zone with very high transmissivity and conductivity exists in the southeast of the terrace in the vicinity of well A-2. This zone coincides with a depression in the top of the PSA unit. Water flowing over Bonney Rock intrusive during Pleistocene floods might have caused this depression and left very transmissive high energy deposits. The region in the northeast of the terrace shows a relatively low transmissivity. This is 
due to a slide block and reworked slide debris that are embedded in the PSA unit in that region. The slide block would also explain the relatively unproductive dewatering wells drilled in the region. The western part of the terrace is more uniform and hydraulic conductivity is somewhat lower than in the eastern part. Here the areal distribution of transmissivities (Figure 28.) reveals the shape of the channel in which the PSA was deposited. The high transmissivity zone is in the center of the buried channel and lower transmissivities occur toward the edges. The relatively high hydraulic conductivity value at piezometer 1632 represents the PSA intermixed with Tanner Creek alluvium as determined in a report by Rittenhouse-Zeman \& Associates (1988).

For the mica sand unit a transmissivity value of $4.75^{\star} 10^{-4} \mathrm{~m}^{2} / \mathrm{s}$ and a conductivity value of $6.8^{\star} 10^{-5} \mathrm{~m} / \mathrm{s}$ was determined from pumping test $\mathrm{A}-1$. Lab tests of mica sand samples gave values of $1 * 10^{-6}-1 * 10^{-5} \mathrm{~m} / \mathrm{s}$ for vertical hydraulic conductivity. Pumping test data analyzed with the Ratio Method gave a value of $2.4^{\star} 10^{-6} \mathrm{~m} / \mathrm{s}$. The specific storage was calculated from consolidation tests to be $0.02 \mathrm{~m}^{-1}$.

For the vertical hydraulic conductivity of the confining layers, the mica sand and b-unit as a whole, a range of $1 * 10^{-6}$ to $1 * 10^{-4} \mathrm{~m} / \mathrm{s}$ was found. This appears to reflect the heterogeneity of the materials of the aquitard layers. 


\section{TABLE I}

IMAGE WELL METHOD, CALCULATED DISTANCES TO IMAGE WELLS AND DISTANCES TO PUMPING WELL FOR

PUMPING TEST $\mathrm{H}-4$

Piezometer,

Monitoring Well No.
Distance to

Pumping Well [m]
Distance to Image Well [m]
H-5 (WW-3)

1612-Z1

$1615-Z 1$

$1611-Z 1$

1624-Z1
72

86

113

246

230
235

318

710

1310

1789 
TABLE ॥

RESPONSE OF SELECTED SHALLOW PIEZOMETERS TO CHANGES IN THE PUMPING RATE FROM THE HATCHERY WELLS

August 8, 1989, 16:05 hrs

Hatchery Well H-5 turned off after pumping at $0.22 \mathrm{~m}^{3} / \mathrm{s}$

\begin{tabular}{clll}
\hline $\begin{array}{c}\text { Observation } \\
\text { Point }\end{array}$ & \multicolumn{3}{c}{ Water Level (m above MSL) } \\
& $8 / 6 / 89$ & $8 / 9 / 89$ & \multicolumn{1}{c}{ Change in } \\
& $17: 00$ & $20: 00$ & Water Level \\
\hline $1624-\mathrm{Z2}$ & 1.52 & 2.29 & +0.77 \\
$1732-\mathrm{Z2}$ & 2.62 & 3.14 & +0.52 \\
$1946-\mathrm{Z2}$ & no data & no data & \\
$1953-\mathrm{Z2}$ & 3.02 & 3.32 & +0.30 \\
River Stage & 2.26 & 2.26 & 0 \\
\hline
\end{tabular}

September 11, 1989, 16:15 hrs

Hatchery Well $\mathrm{H}-3$ turned on at $0.24 \mathrm{~m}^{3} / \mathrm{s}$

\begin{tabular}{llll}
\hline $\begin{array}{l}\text { Observation } \\
\text { Point }\end{array}$ & \multicolumn{3}{c}{ Water Level (m above MSL) } \\
& $\begin{array}{l}\text { 9/11/89 } \\
15: 00\end{array}$ & $\begin{array}{l}9 / 12 / 89 \\
18: 00\end{array}$ & $\begin{array}{c}\text { Change in } \\
\text { Water Level }\end{array}$ \\
& 1.52 & 1.31 & -0.21 \\
$1624-Z 2$ & 2.74 & 2.38 & -0.36 \\
$1732-Z 2$ & 2.01 & 1.74 & -0.27 \\
$1946-Z 2$ & 2.90 & 2.74 & -0.26 \\
$1953-Z 2$ & 2.41 & 2.41 & 0 \\
River Stage & & & \\
\hline
\end{tabular}


TABLE III RESULTS OF DIFFERENT PUMPING TEST ANALYSIS METHODS,
PUMPING WELLS H-3 AND H-4

\begin{tabular}{|c|c|c|c|c|c|c|c|c|c|}
\hline \multirow{2}{*}{$\begin{array}{l}\text { Preromeler, } \\
\text { Monliboring } \\
\text { Well Na. }\end{array}$} & \multirow[t]{2}{*}{$\begin{array}{l}\text { Punping } \\
\text { Teat }\end{array}$} & \multicolumn{2}{|c|}{ 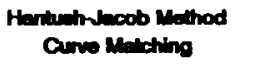 } & \multicolumn{2}{|c|}{$\begin{array}{l}\text { Henturitndescob Method } \\
\text { TSSIEAK }\end{array}$} & \multicolumn{2}{|c|}{ Jecob Method } & \multicolumn{2}{|c|}{ Theil Method } \\
\hline & & $T\left(m^{2} / 8\right)$ & $\mathbf{s}$ & $T\left(m^{2} / s\right)$ & $\mathbf{s}$ & $T\left(m^{2} / 8\right)$ & $\mathbf{s}$ & $T\left(m^{2} / s\right)$ & $\mathbf{s}$ \\
\hline $1610-Z 1^{(1)}$ & $\mathrm{H}-3$ & $1.02^{*} 10^{-2}$ & $2.8^{*} 10^{-4}$ & $1.00^{*} 10^{-2}$ & $2.0^{*} 10^{-4}$ & $1.90 * 10^{-2}$ & $2.2^{*} 10^{-4}$ & & \\
\hline \multirow[t]{2}{*}{$1611-Z 1$} & $\mathrm{H}_{3}$ & $2.10^{*} 10^{-2}$ & $3.0^{*} 10^{-4}$ & $2.13^{*} 10^{-2}$ & $2.8 * 10^{-4}$ & $2.33^{*} 10^{-2}$ & $2.6^{*} 10^{-4}$ & $2.11 * 10^{-2}$ & $1.8^{*} 10^{-4}$ \\
\hline & $\mathrm{H}-4$ & $2.75 * 10^{-2}$ & $1.8^{*} 10^{-4}$ & $2.79^{*} 10^{-2}$ & $1.7 * 10^{-4}$ & $2.85 * 10^{-2}$ & $1.4^{*} 10^{-4}$ & & \\
\hline \multirow[t]{2}{*}{$1612-Z 1^{(2)}$} & $\mathrm{H}_{3}$ & $1.44 * 10^{-2}$ & $1.7 * 10^{-2}$ & $1.17 * 10^{-2}$ & $1.7^{*} 10^{-2}$ & $2.25 * 10^{-2}$ & $1.7^{*} 10^{-3}$ & $2.24^{*} 10^{-2}$ & $1.5 * 10^{-3}$ \\
\hline & $\mathrm{H}-4$ & $2.25 * 10^{-2}$ & $1.5^{*} 10^{-3}$ & $2.22 * 10^{-2}$ & $1.5^{*}+10^{-3}$ & $2.75^{*} 10^{-2}$ & $1.0^{*} 10^{-3}$ & & \\
\hline $1615-Z 1$ & $\mathrm{H}-4$ & $2.82 * 10^{-2}$ & $3.3^{*} 10^{-4}$ & $2.77 * 10^{-2}$ & $3.8 * 10^{-4}$ & $2.85 * 10^{-2}$ & $3.2^{*} 10^{-4}$ & $2.65^{*} 10^{-2}$ & $4.0^{*} 10^{-4}$ \\
\hline $1624-Z 1^{(3)}$ & $\mathrm{H}-4$ & $1.85 * 10^{-2}$ & $1.2 * 10^{-4}$ & & & & & $2.47 * 10^{-2}$ & $0.2^{*} 10^{-5}$ \\
\hline $1628-Z 1$ & $\mathrm{H}-4$ & $1.48 * 10^{-2}$ & $3.6 * 10^{-5}$ & $1.48 * 10^{-2}$ & $4.2^{*} 10^{-5}$ & $2.28 * 10^{-2}$ & $2.5^{*} 10^{-5}$ & & \\
\hline $1632-Z 1$ & $\mathrm{H}-4$ & $2.39 * 10^{-2}$ & $7.0^{*} 10^{-5}$ & $2.49 * 10^{-2}$ & $6.8^{*} 10^{-5}$ & $3.11 * 10^{-2}$ & $5.5^{*} 10^{-5}$ & & \\
\hline $1730-z 1^{(4)}$ & $\mathrm{H}-4$ & & & & & $1.78 * 10^{-2}$ & $2.9^{m} 10^{-5}$ & & \\
\hline$w w-1794^{(5)}$ & $\mathrm{H}-4$ & $1.98 * 10^{-2}$ & $8.4^{* 1} 10^{-4}$ & & & & & & \\
\hline WW-3 (H-5) & $\mathrm{H}-4$ & $2.32 * 10^{-2}$ & $3.5 * 10^{-3}$ & $2.32 * 10^{-2}$ & $3.5^{*} 10^{-3}$ & $2.63^{*} 10^{-2}$ & $3.1 * 10^{-3}$ & $2.01 * 10^{-2}$ & $1.8^{*} 10^{-3}$ \\
\hline $\mathrm{H}-3$ & $\mathrm{H}-3$ & $2.62 * 10^{-2}$ & & & & $2.41 * 10^{-2}$ & & & \\
\hline
\end{tabular}

(1) Hantush-Jacob Method affected by large earty drawdown
(2) close to pumping well, affected by partial penetration effects
(3)
two water level readings only
(4)
(5) boundary effects due to proximity to Bonney Rock 
TABLE IV

\section{SUMMARY OF RESULTS OF PUMPING TEST ANALYSIS FOR THE PSA AQUIFER ${ }^{(1)}$}

\begin{tabular}{|c|c|c|c|c|}
\hline $\begin{array}{l}\text { Piezometer, } \\
\text { Monitoring } \\
\text { Well No. }\end{array}$ & Pumping Tests & $\begin{array}{c}\text { Transmissivity } \\
\left(\mathrm{m}^{2} / \mathrm{s}\right)\end{array}$ & $\begin{array}{l}\text { Hydraulic } \\
\text { Conductivity } \\
(\mathrm{m} / \mathrm{s})^{(\mathrm{z})}\end{array}$ & Storativity ${ }^{(3)}$ \\
\hline $\begin{array}{c}1610-Z 1 \\
1611-Z 1 \\
1612-Z 1 \\
1615-Z \\
1624-Z 1\end{array}$ & $\begin{array}{c}H-3, H-4 \\
H-3, H-4 \\
H-3, H-4 \\
H-4 \\
H-4\end{array}$ & $\begin{array}{l}1.98^{\star} 10^{-2} \\
2.45^{\star} 10^{-2} \\
2.37^{\star} 10^{-2} \\
2.80^{\star} 10^{-2} \\
1.87^{\star} 10^{-2}\end{array}$ & $\begin{array}{l}6.04 * 10^{-4} \\
6.28 * 10^{-4} \\
5.66^{*} 10^{-4} \\
6.89 * 10^{-4} \\
5.70^{*} 10^{-4}\end{array}$ & $\begin{array}{l}2.2^{\star} 10^{-4} \\
2.0^{\star} 10^{-4} \\
1.5^{\star} 10^{-3} \\
3.4^{\star} 10^{-4} \\
1.2^{\star} 10^{-4}\end{array}$ \\
\hline $\begin{array}{l}1629-Z 1 \\
1632-Z 1 \\
1730-Z 2 \\
1738-Z 1 \\
1741-Z 1\end{array}$ & $\begin{array}{c}H-4, A-2 \\
H-4 \\
H-4 \\
A-2 \\
A-2\end{array}$ & $\begin{array}{l}1.58^{\star} 10^{-2} \\
2.59^{\star} 10^{-2} \\
1.78^{\star} 10^{-2} \\
2.75^{\star} 10^{-2} \\
2.67^{\star} 10^{-2}\end{array}$ & $\begin{array}{l}5.40 * 10^{-4} \\
1.42 * 10^{-3} \\
1.09 * 10^{-3} \\
6.61 * 10^{-4} \\
1.90 * 10^{-3}\end{array}$ & $\begin{array}{l}3.0^{\star} 10^{-5} \\
6.5 * 10^{-4} \\
2.9^{\star} 10^{-5} \\
2.5^{\star} 10^{-3} \\
2.0^{\star} 10^{-3}\end{array}$ \\
\hline $\begin{array}{c}1743-Z 1 \\
1745-Z 1 \\
1746-Z 1 \\
1747-Z 1 \\
W W-1794\end{array}$ & $\begin{array}{c}\text { A-2 } \\
\text { A-2 } \\
\text { A-2 } \\
\text { A-2 } \\
\text { A-2, Pumping Well }\end{array}$ & $\begin{array}{l}2.80^{\star} 10^{-2} \\
1.87^{\star} 10^{-2} \\
3.31 * 10^{-2} \\
3.31 * 10^{-2} \\
2.45^{\star} 10^{-2}\end{array}$ & $\begin{array}{l}1.92^{*} 10^{-3} \\
6.09 * 10^{-4} \\
2.79 * 10^{-4} \\
2.52 * 10^{-3} \\
9.80^{*} 10^{-4}\end{array}$ & $\begin{array}{c}7.0^{\star} 10^{-3} \\
- \\
8.4^{\star} 10^{-4}\end{array}$ \\
\hline $\begin{array}{c}W W-3(H-5) \\
H-3 \\
W W-1800 \\
W W-1805 \\
W W-2030^{(4)} \\
W W-2033\end{array}$ & $\begin{array}{c}\text { H-4 } \\
\text { Pumping Well } \\
\text { Pumping Well } \\
\text { Pumping Well A-2 } \\
\text { Pumping Well } \\
\text { Pumping Well }\end{array}$ & $\begin{array}{c}2.32^{\star} 10^{-2} \\
2.42^{\star} 10^{-2} \\
4.03^{\star} 10^{-3} \\
3.02^{\star} 10^{-2} \\
1.3^{\star} 10^{-2} \\
2.73^{*} 10^{-4}\end{array}$ & $\begin{array}{l}5.48^{\star} 10^{-4} \\
5.76^{\star} 10^{-4} \\
1.47^{\star} 10^{-4} \\
2.30 * 10^{-3} \\
\cdot \\
7.16^{\star} 10^{-6}\end{array}$ & $\begin{array}{c}3.3^{\star} 10^{-3} \\
- \\
- \\
- \\
- \\
-\end{array}$ \\
\hline
\end{tabular}

(1)

(2)

(3)

(4)

Values are averaged from results of different methods and different pumping tests.

Conductivity was calculated from aquifer transmissivity and PSA thicknesses from Rittenhouse-Zeman \& Associates. (1988).

Storativity values for piezometers $1743-Z 1,1746-Z 1$ and $1747-Z 1$ and for the pumping wells were not calculated because no correct values can be obtained in the immediate vicinity of the pumping wells.

From Robinson \& Noble, Inc. (1988). Only aquifer transmissivity was calculated. 
TABLE $V$

\section{VERTICAL HYDRAULIC CONDUCTIVITY OF THE AQUITARD LAYERS B-UNIT AND MICA SAND, HANTUSH-JACOB METHOD}

\begin{tabular}{ccc}
\hline $\begin{array}{c}\text { Piezometer, } \\
\text { Monitoring Well Number }\end{array}$ & $\begin{array}{c}\text { Distance } \\
\text { from Pumping Well } \\
{[\mathrm{m}]}\end{array}$ & $\begin{array}{c}\text { Vertical Hydraulic Conductivity } \\
{[\mathrm{m} / \mathrm{s}]}\end{array}$ \\
\hline & & \\
1610 & 230 & $2.2^{\star} 10^{-8}$ \\
1611 & 246 & $8.5^{\star} 10^{-7}$ \\
1612 & 86 & $8.5^{\star} 10^{-6}$ \\
1615 & 113 & $1.4^{\star} 10^{-8}$ \\
1624 & 230 & $1.4^{\star} 10^{-8}$ \\
1629 & 192 & $3.8^{\star} 10^{-7}$ \\
1632 & 391 & $8.0^{\star} 10^{-7}$ \\
1738 & 170 & $4.7^{\star} 10^{-8}$ \\
1741 & 58 & $2.4^{\star} 10^{-5}$ \\
1743 & 22 & $1.5^{\star} 10^{-4}$ \\
1745 & & \\
1746 & 65 & $2.8^{\star} 10^{-5}$ \\
1794 & 7 & $1.5^{\star} 10^{-4}$ \\
WW-3 & 183 & $2.8^{\star} 10^{-6}$ \\
& 49 & $2.1^{\star} 10^{-5}$ \\
\hline
\end{tabular}




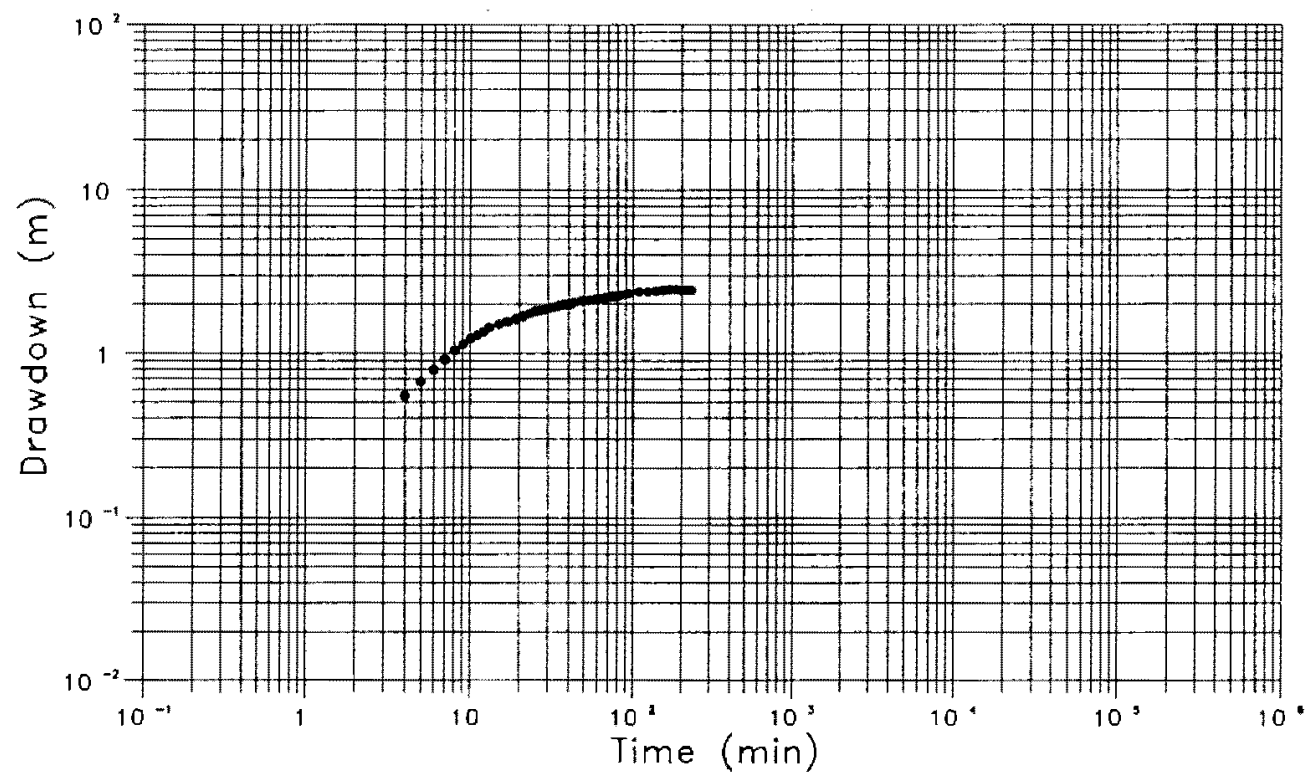

Figure 5. Time-drawdown plot from piezometer 1612-Z1 during the pumping test in fish hatchery well $\mathrm{H}-3$. 
A) Drawdown in the piezometric surface of a confined aquifer bounded by a stream.

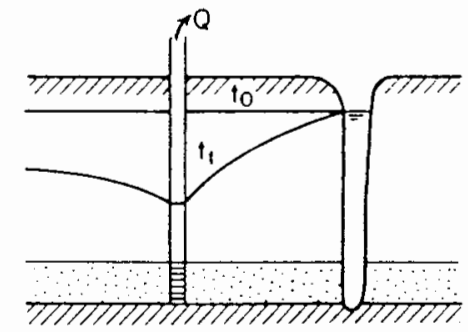

B) Equivalent system of infinite extent.

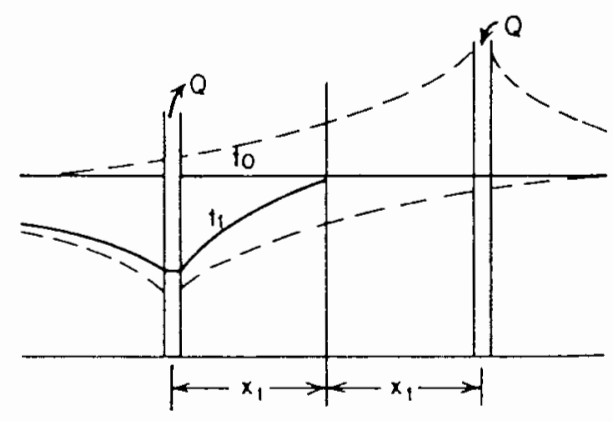

C) Plan view.

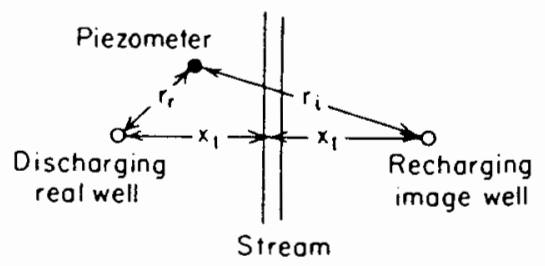

\section{Legend}

Q pumping rate, injection rate

$h_{0} \quad$ piezometric surface without pumping

$h_{1} \quad$ piezometric surface with pumping

$x_{1}$ distance from the real well to the boundary, distance from the image well to the boundary

$r$ distance from the real well to the piezometer

$r_{i}$ distance from the image well to the piezometer

Figure 6. Representation of a hydrogeologic recharge boundary with an image well. After Cherry and Freeze (1979). 


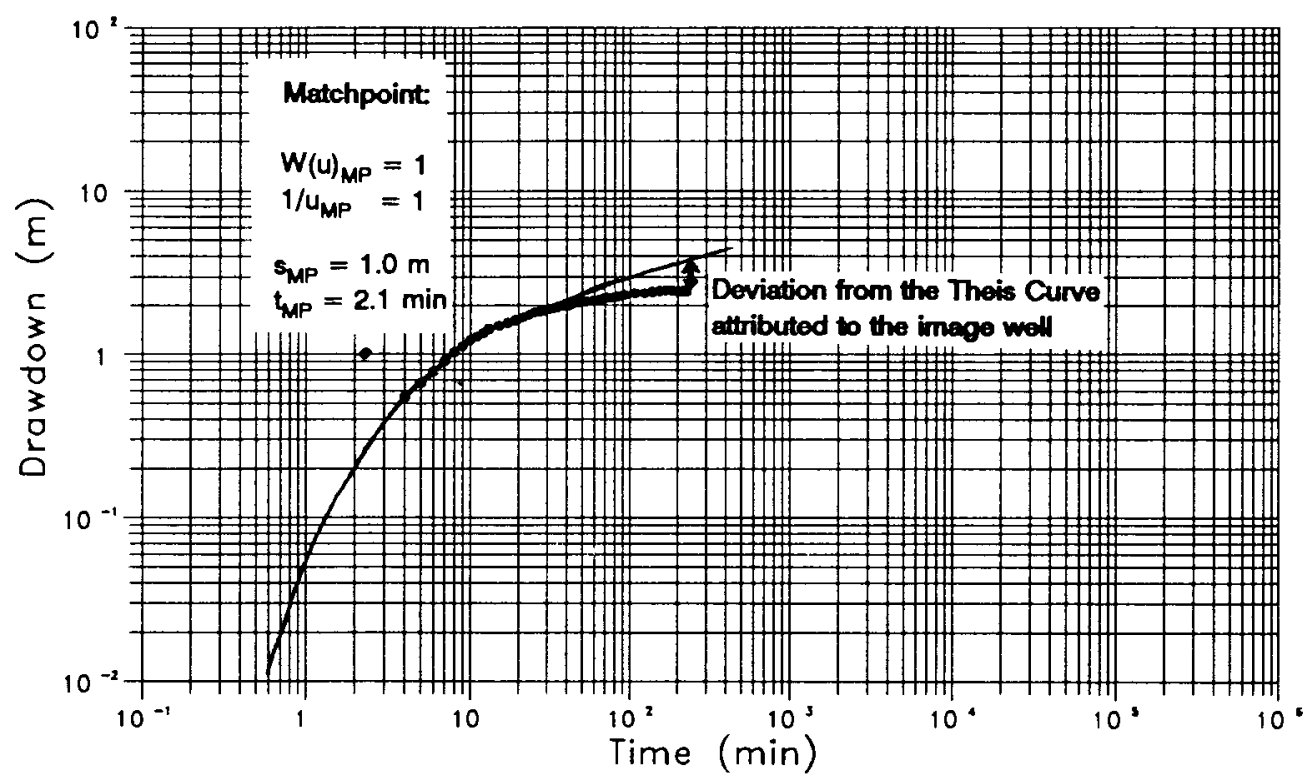

$$
r_{i}=r_{r} \times \sqrt{\frac{t_{i}}{t_{r}}}=85.7 \mathrm{~m} \times \sqrt{\frac{110 \mathrm{~min}}{8 \mathrm{~min}}}=318 \mathrm{~m}
$$

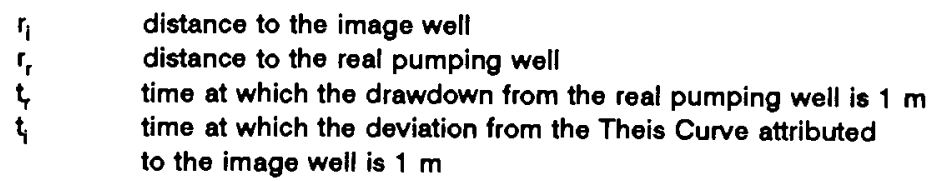

$W(u)_{M P} W(u)$ value of the well function plot at the matchpoint

$1 / \mathrm{u}_{M P} \quad 1 / \mathrm{u}$ value of the well function plot at the matchpoint

$s_{\text {MP }}$ drawdown value at the matchpoint

MP time value at the matchpoint

Figure 7 . Image well method, determination of the distance to an image well. After Heath and Trainer (1968). 


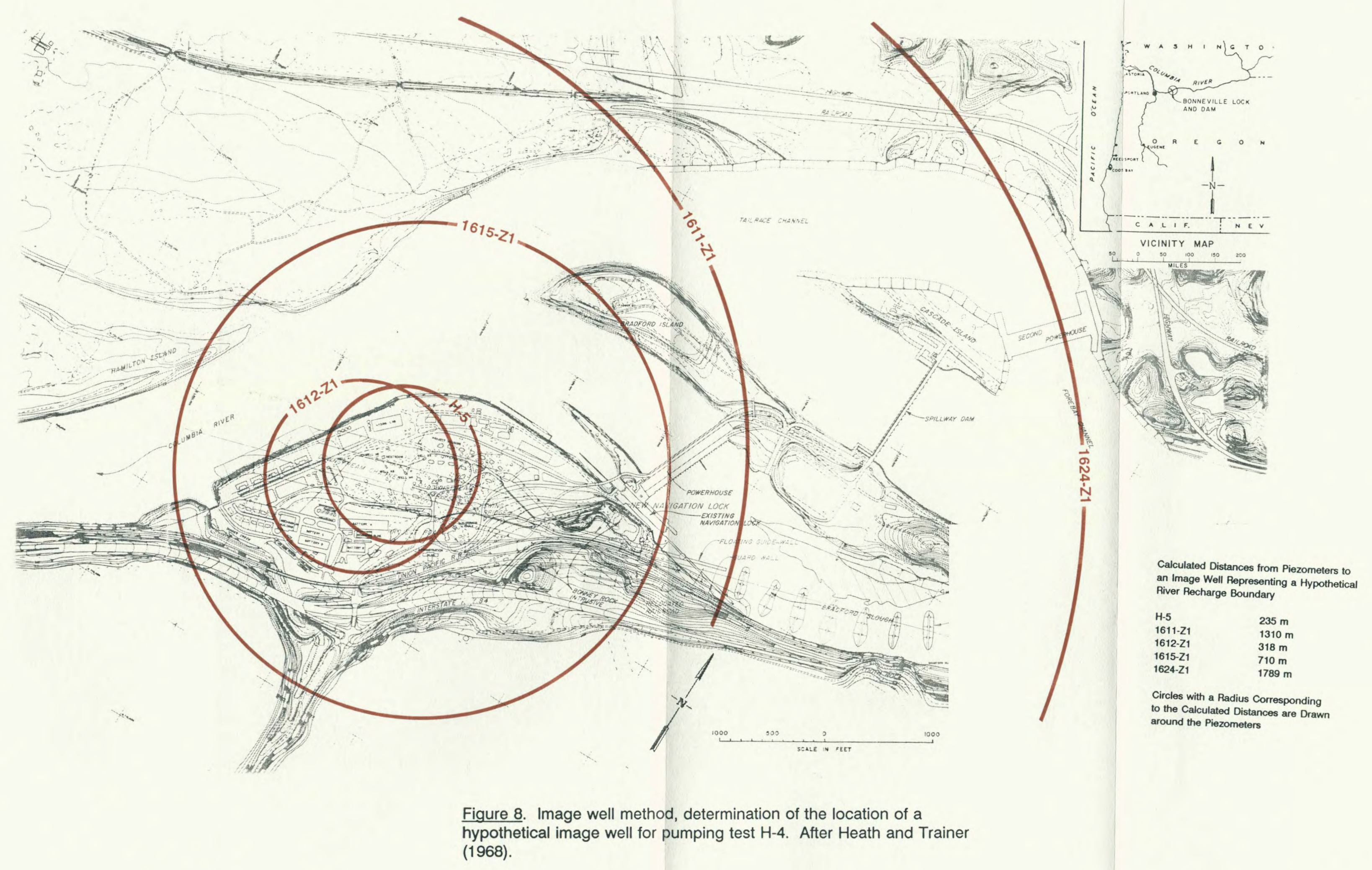




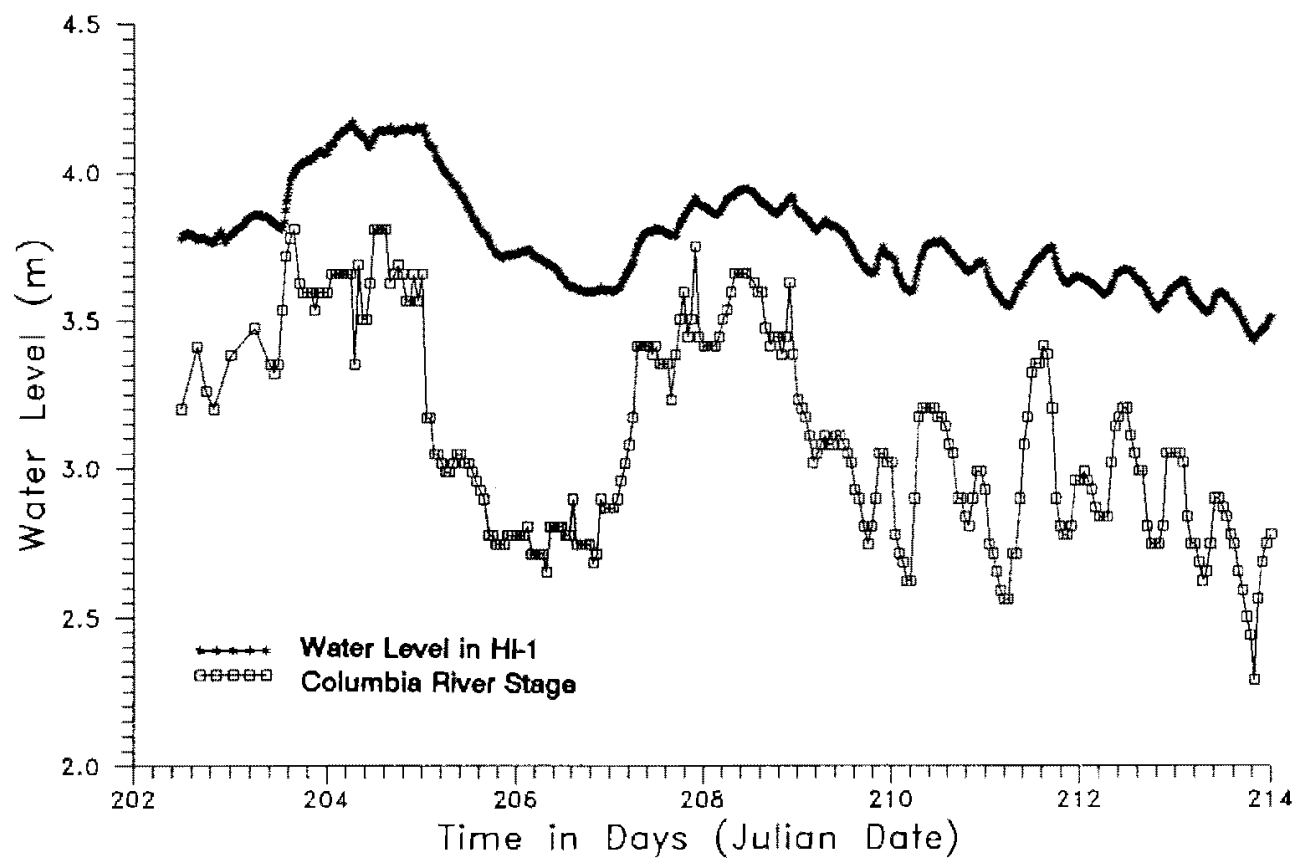

Figure 9. Water level in piezometer $\mathrm{HI}-1$ and Columbia River stage during the period from July 20 to August 1, 1988. 


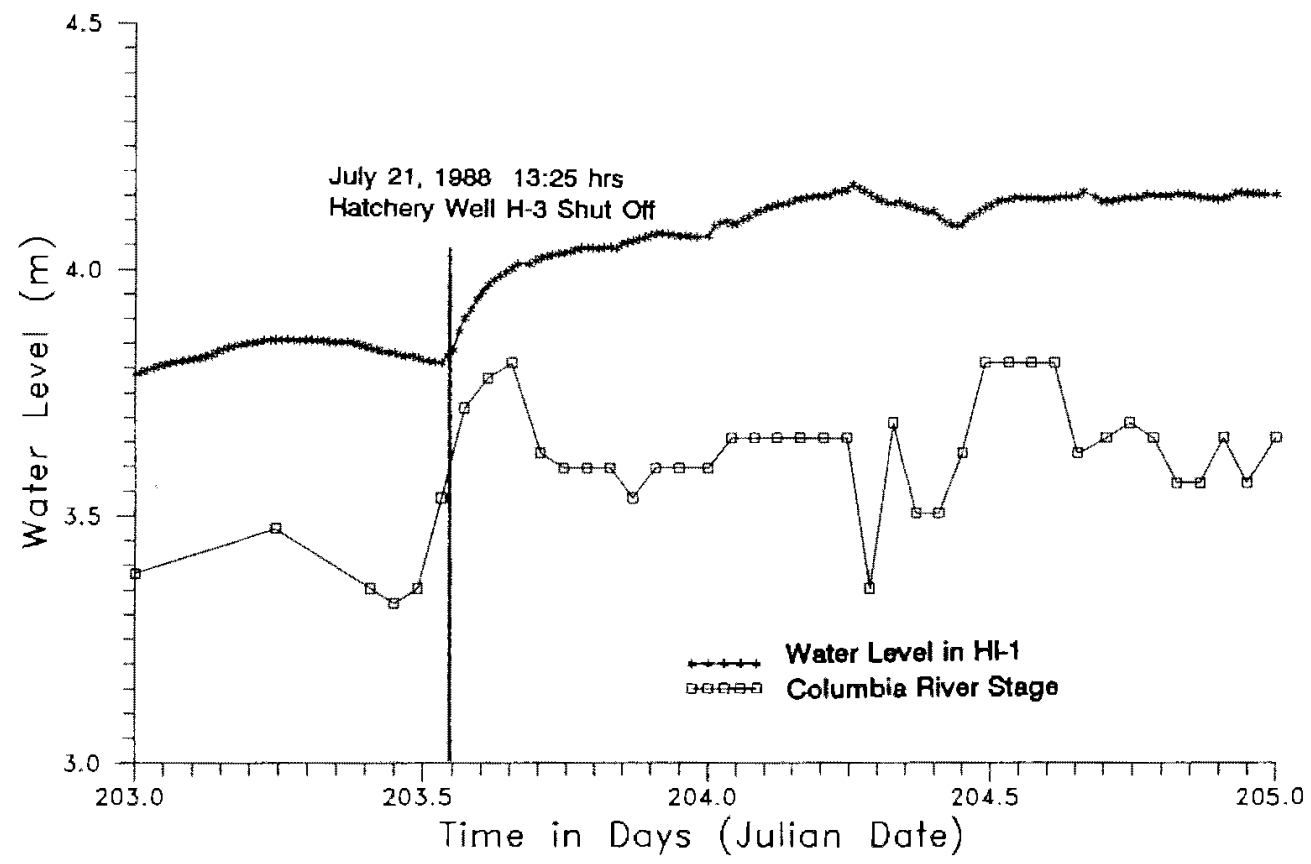

Figure 10. Effect of turning off hatchery well H-3 on piezometer $\mathrm{HI}-1$. 


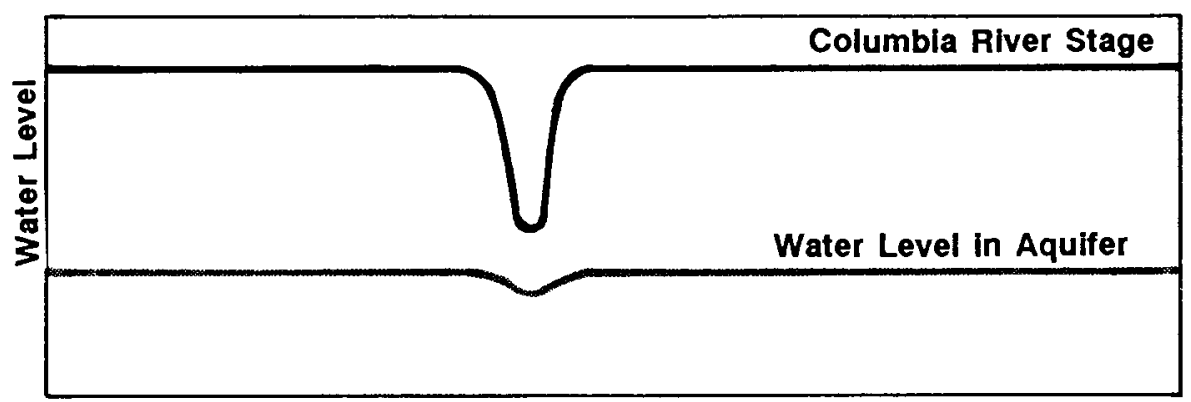

Time

A) River stage changes for a short period of time. Water level in the aquifer fluctuates only to a small extent because of the response time of the system.

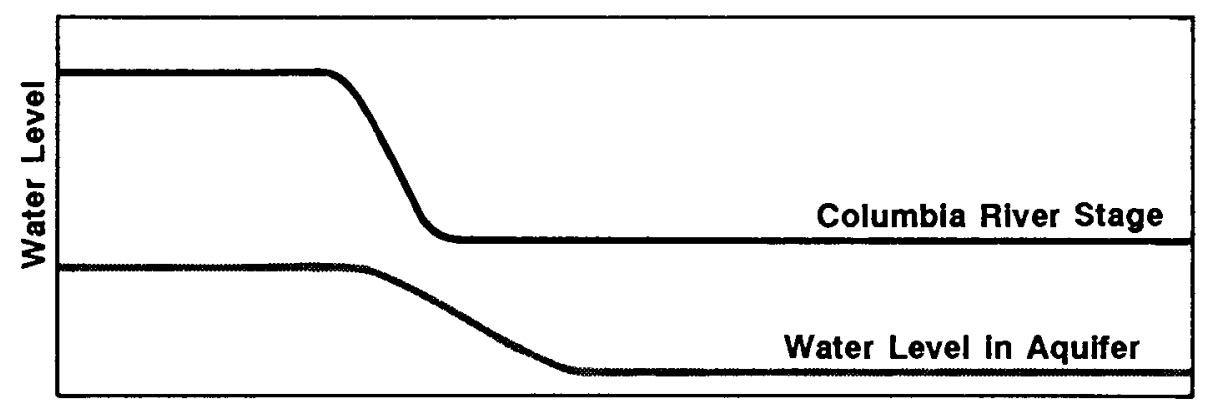

Time

B) River stage changes for a prolonged period of time. Water level in the aquifer has time to respond and reflects the change in river stage.

Figure 11. Effect of different Columbia River stage changes on water level in the aquifer. 


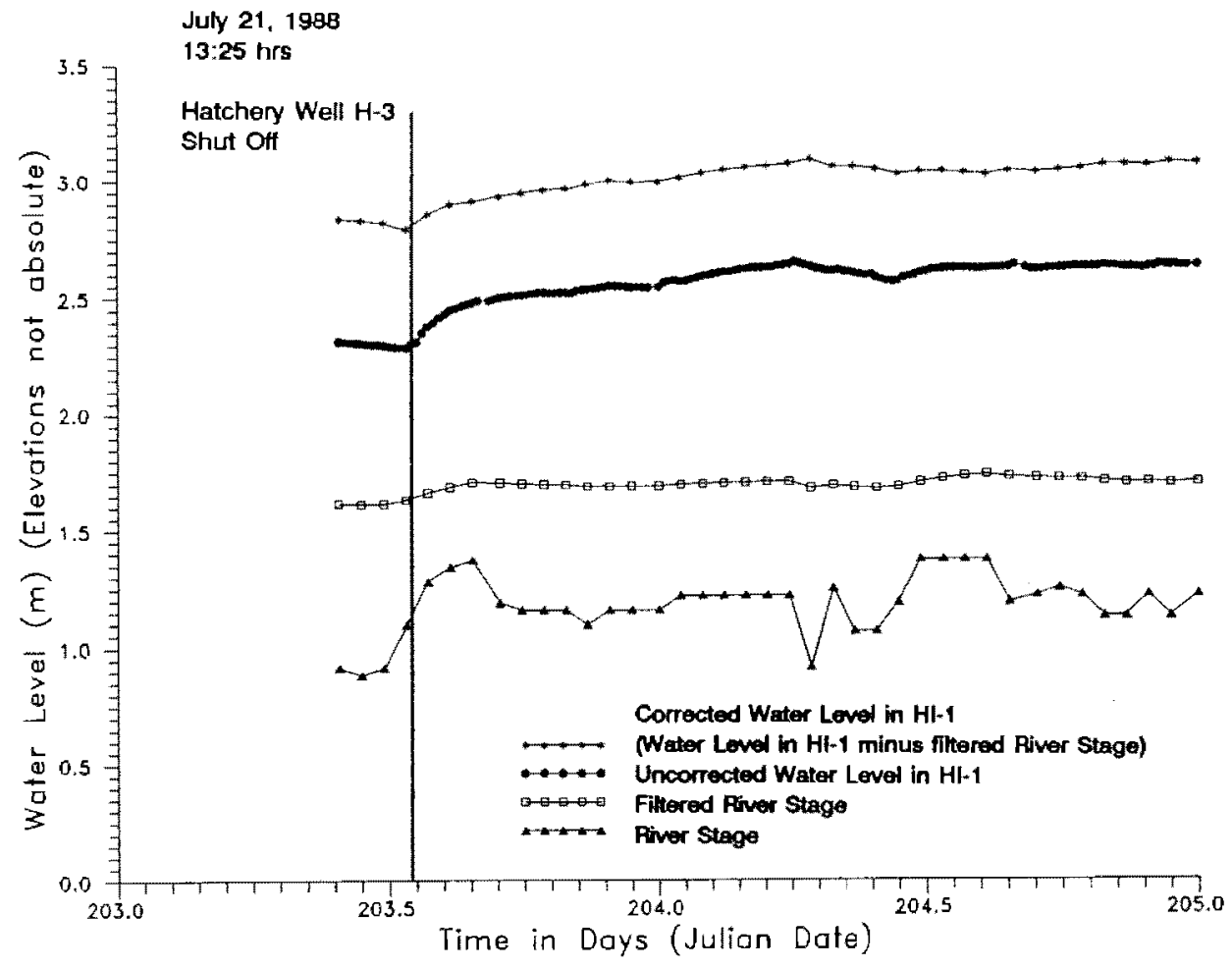

Figure 12. Correction of the water level in piezometer $\mathrm{HI}-1$ for the influence of fluctuations of the Columbia River stage. 


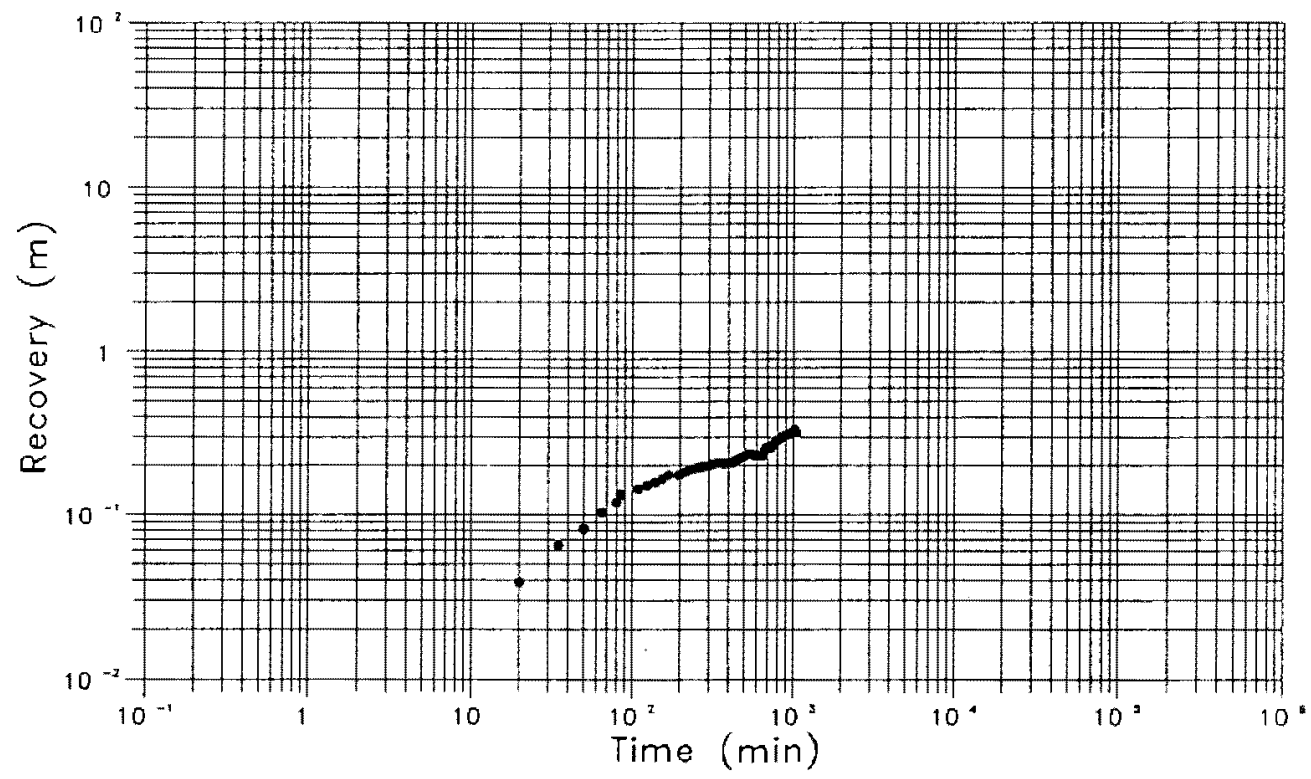

Figure 13. Recovery of the water level in piezometer HI-1 after turning off hatchery well $\mathrm{H}-3$. Water level is corrected for the influence of Columbia River stage fluctuations. 


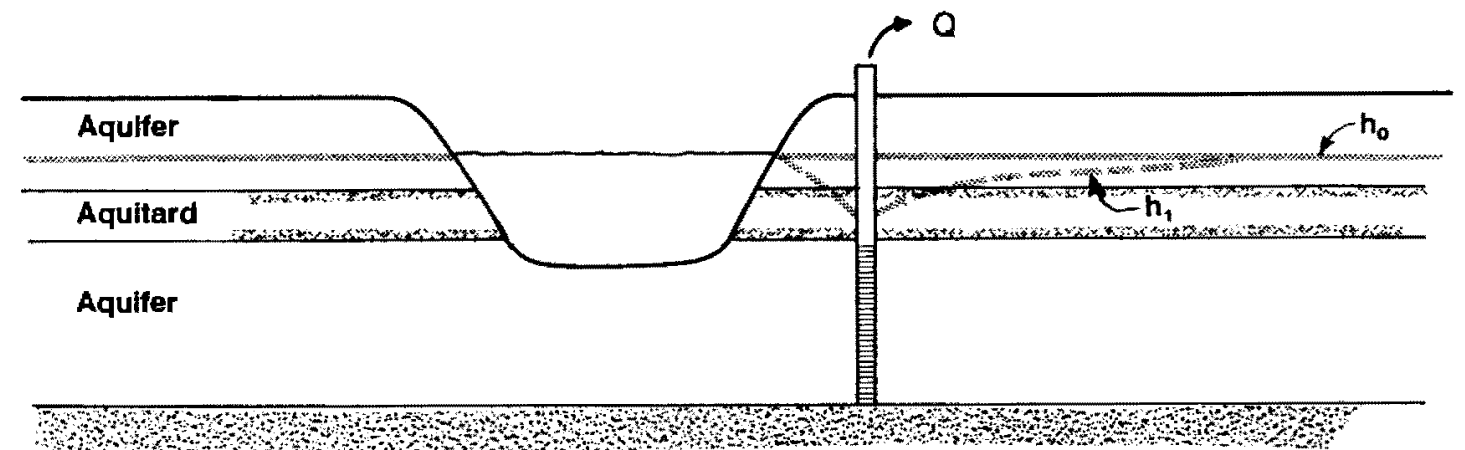

A) Aquifer is in direct connection to the river.

No drawdown occurs across the river.

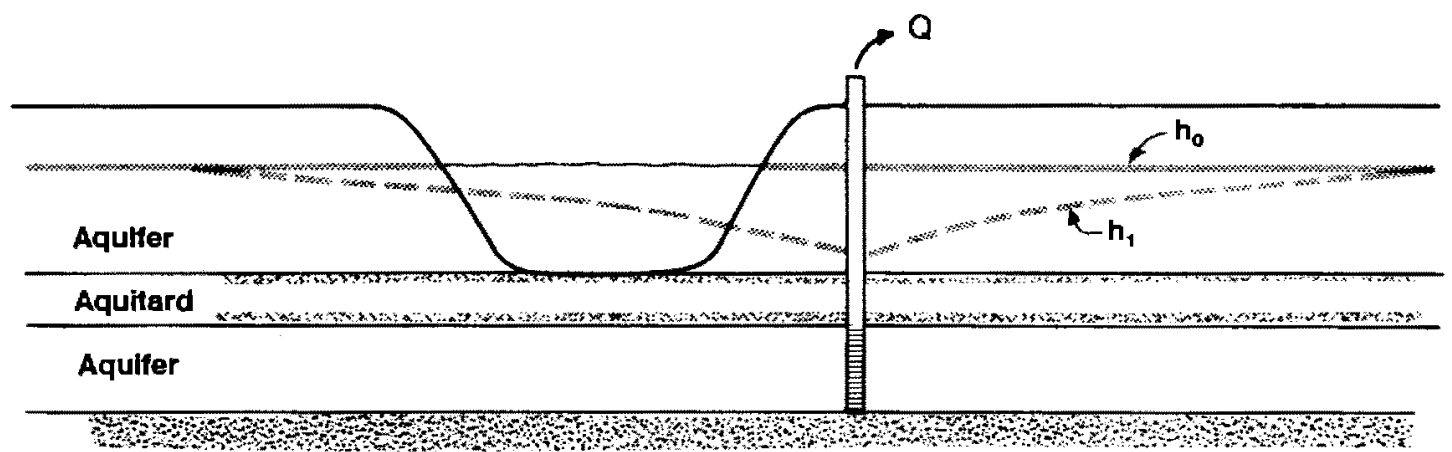

B) Aquifer is effectively separated from the river.

Drawdown across the river can be observed.

$h_{0} \quad$ Initial Piezometric Surface without Pumping

$h_{1}$ Piezometric Surface during Pumping

o Pumping Rate

Figure 14. Scenarios for the interaction of a river and a confined aquifer. 


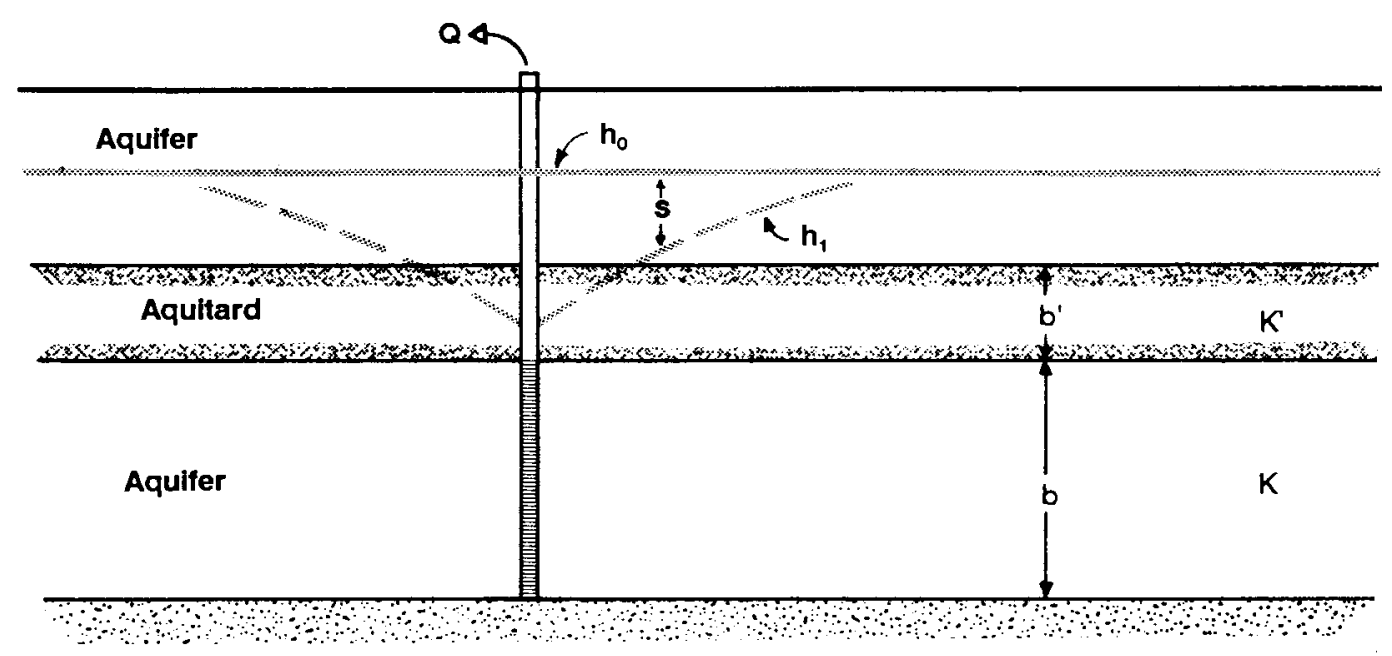

\section{Legend}

$h_{0} \quad$ Initial Piezometric Surface without Pumping

$h_{1}$ Piezometric Surface during Pumping

$Q$ Pumping Rate

$s$ Drawdown

b Thickness of the Aquifer

b' Thickness of the Aquitard

$\mathrm{K}$ Hydraulic Conductivity of the Aquifer

$K^{\prime}$ Hydraulic Conductivity of the Aquitard

Figure 15. Leaky aquifer system. 


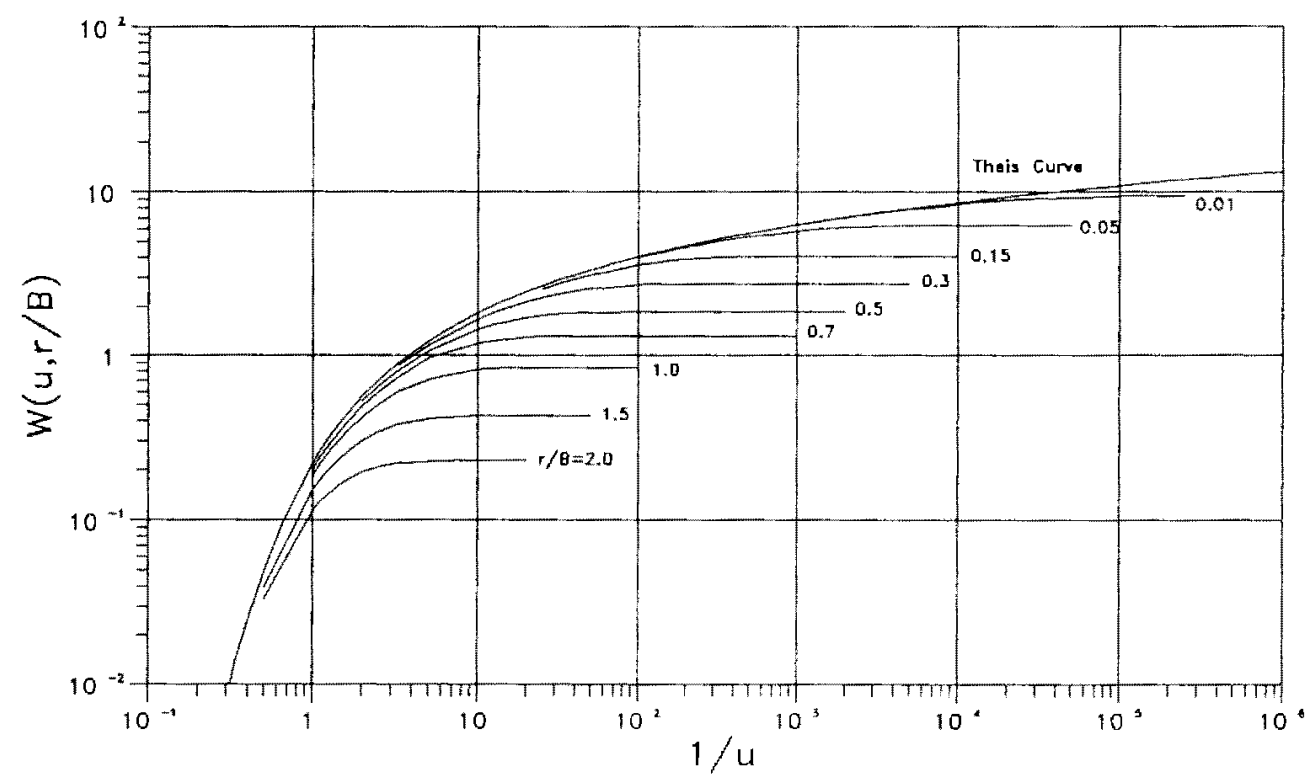

Figure 16. $W(u, r / B)$ Type curves for leaky aquifers. After Fetter (1988). 


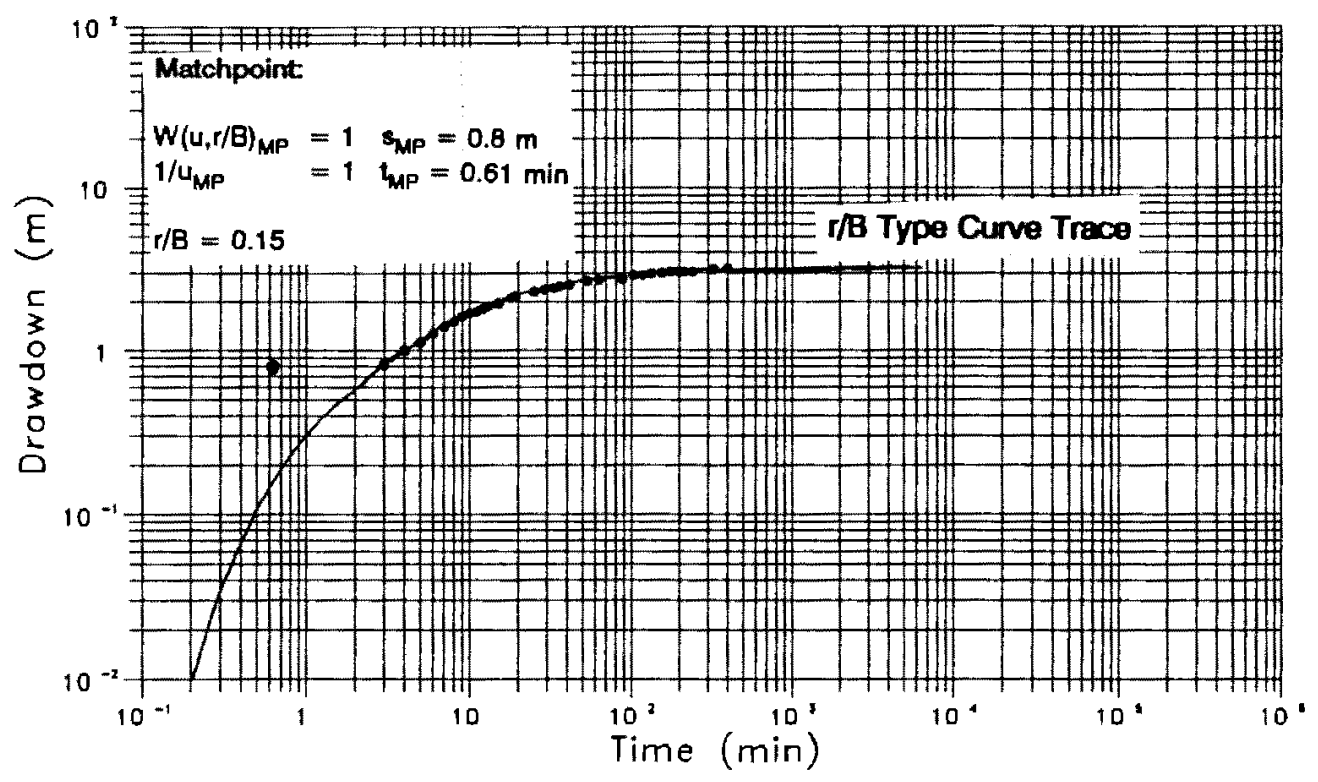

$$
\begin{gathered}
T=\frac{Q \times W(u, r / B)_{M P}}{4 \times \pi \times s_{M P}}=\frac{0.284 \mathrm{~m}^{3} / \mathrm{s} \times 1}{4 \times \pi \times 0.8 \mathrm{~m}}=2.83 \times 10^{-2} \mathrm{~m}^{2} / \mathrm{s} \\
S=\frac{4 \times T \times t_{M P}}{r^{2} \times u_{M P}}=\frac{4 \times 2.83 \times 10^{-2} \mathrm{~m}^{2} / \mathrm{s} \times 36.6 \mathrm{~s}}{(112.5 \mathrm{~m})^{2} \times 1}=3.3 \times 10^{-4} \\
K^{\prime}=\frac{T \times b^{\prime} \times(r / B)^{2}}{r^{2}}=\frac{2.83 \times 10^{-2} \mathrm{~m}^{2} / \mathrm{s} \times 25.6 \mathrm{~m} \times 0.15^{2}}{(112.5 \mathrm{~m})^{2}}=1.3 \times 10^{-6} \mathrm{~m} / \mathrm{s}
\end{gathered}
$$

T transmisslulty

Q pumping rate

S Storativity

r distance from the well to the piezometer

K hydraulic conductivity of the aquitard

b' thickness of the aquitard

r/B leakage factor

$\begin{array}{ll}W(u, r / B)_{\text {MP }} & \begin{array}{l}W(u, r / B) \text { value of the plot of the well function for } \\ \text { leaky aquifers at the matchpoint } \\ 1 / u \text { value of the plot of the well function for } \\ \text { leaky aquifers at the matchpoint } \\ 1 / u_{\text {MP }}\end{array} \\ \begin{array}{l}\text { drawdown value at the matchpoint } \\ \text { MPP }\end{array} & \begin{array}{l}\text { time value at the matchpoint } \\ \text { MP }\end{array}\end{array}$

Figure 17. Determination of aquifer parameters with the Hantush-Jacob Method for leaky aquifers. After Fetter (1988). Time-drawdown data is from piezometer $1615-\mathrm{Z} 1$ during the pumping test in hatchery well $\mathrm{H}-4$. 


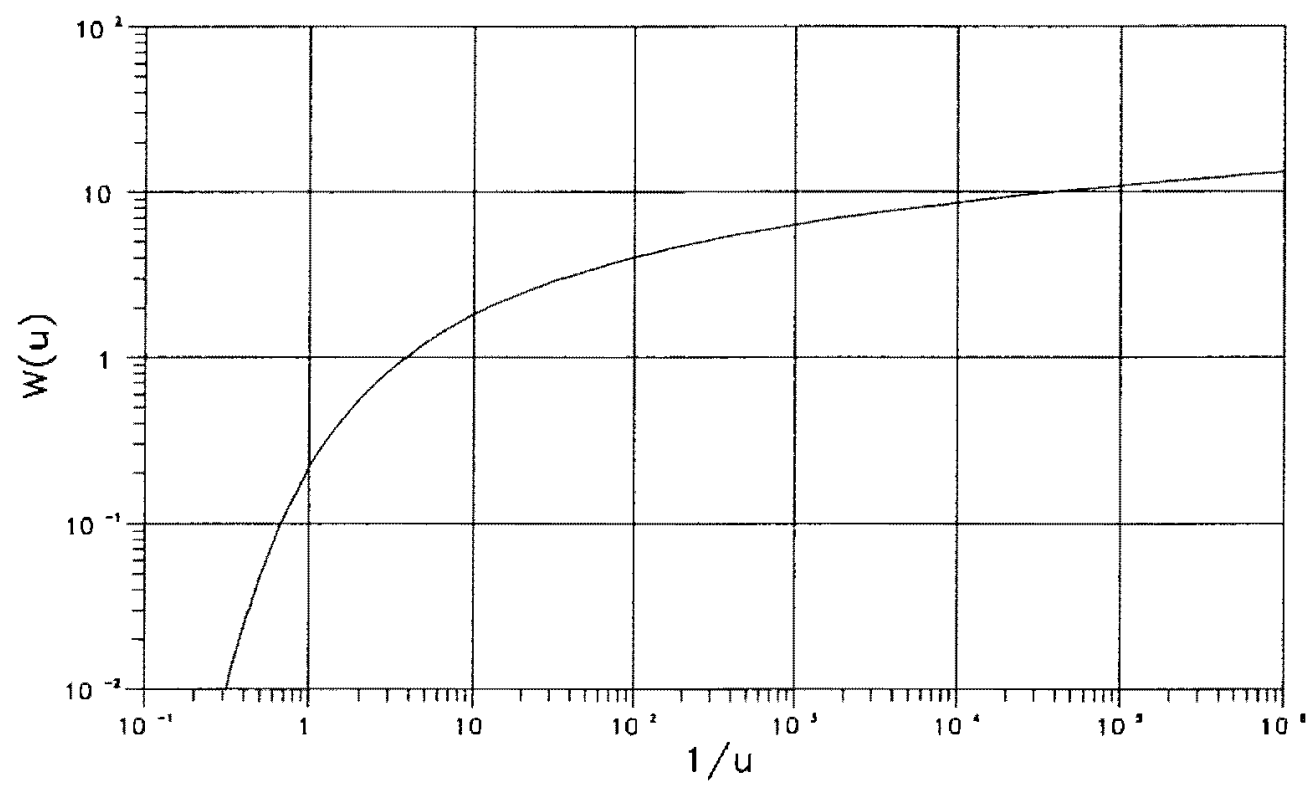

Figure 18. Reversed Theis type curve. After Fetter (1988). 


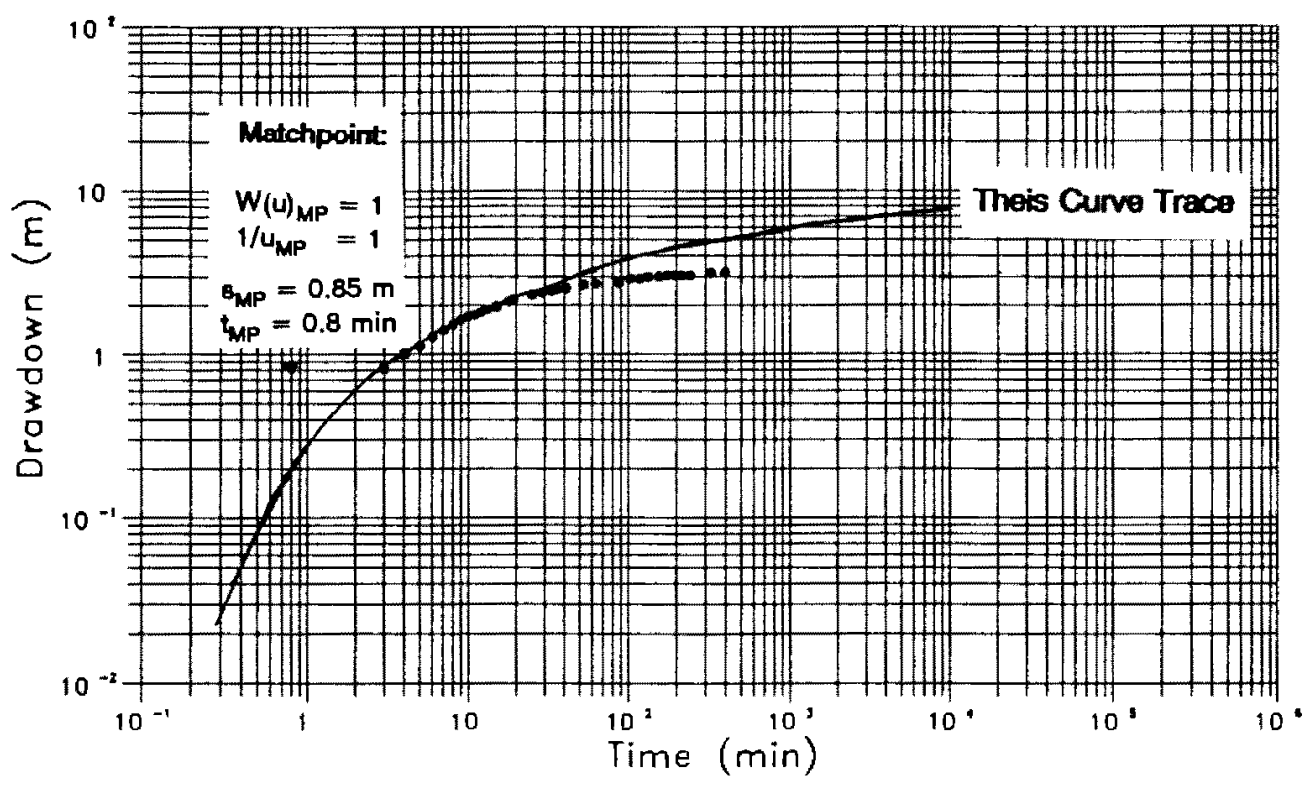

$$
T=\frac{Q \times W(u)_{M P}}{4 \times \pi \times s_{M P}}=\frac{0.284 \mathrm{~m}^{3} / \mathrm{s} \times 1}{4 \times \pi \times 0.85 \mathrm{~m}}=2.65 \times 10^{-2} \mathrm{~m}^{2} / \mathrm{s}
$$

$S=\frac{4 \times T \times t_{M P}}{T_{X U_{M P}}}=\frac{4 \times 2.65 \times 10^{-2} \mathrm{~m}^{2} / \mathrm{s} \times 48 \mathrm{~s}}{(112.5 \mathrm{~m})^{2} \times 1}=4.0 \times 10^{-4}$

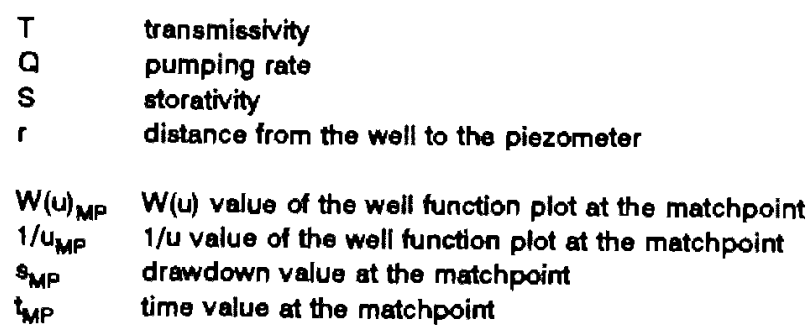

Figure 19. Determination of aquifer parameters with the Theis Method. After Fetter (1988). Time-drawdown data is from piezometer 1615-Z1 during the pumping test in hatchery well $\mathrm{H}-4$. 


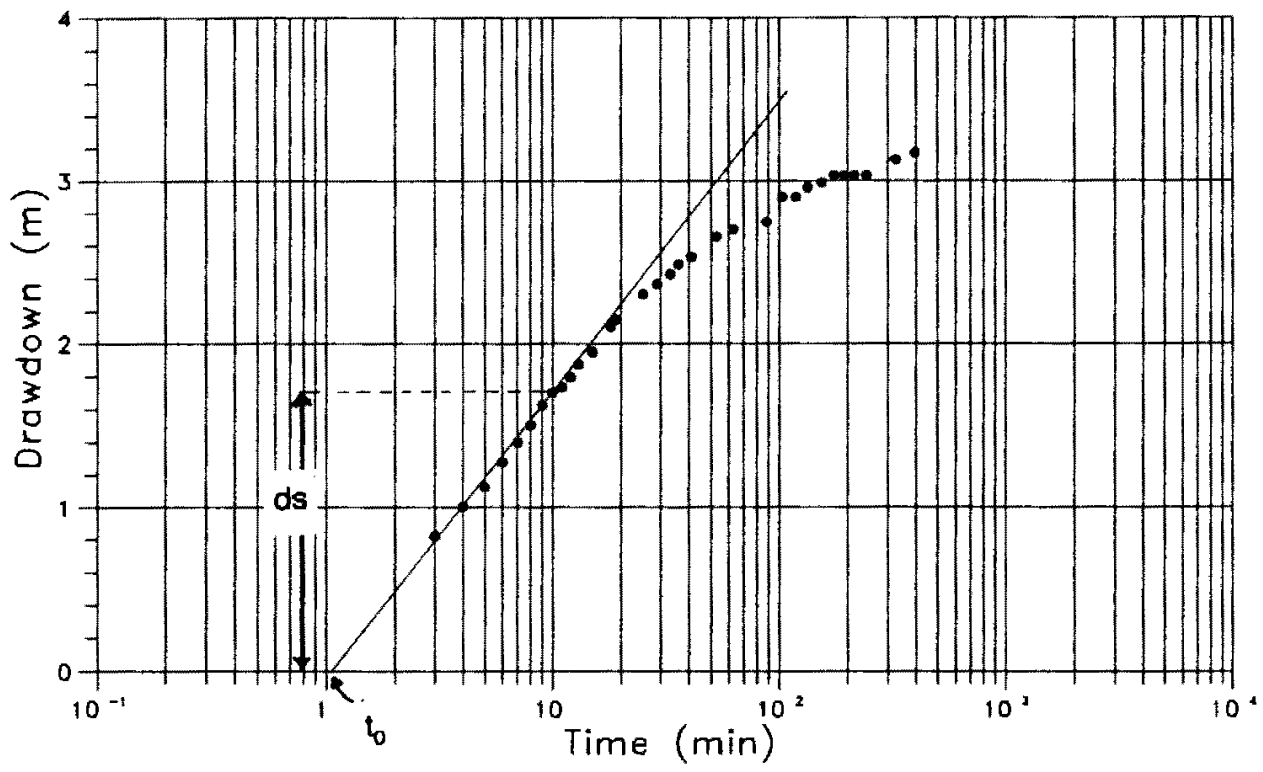

$T=\frac{Q \times 0.183}{d s}=\frac{0.284 \mathrm{~m}^{3} / \mathrm{s} \times 0.183}{1.75 \mathrm{~m}}=2.97 \times 10^{-2} \mathrm{~m} / \mathrm{s}$

$S=\frac{T \times t_{0} \times 2.25}{r^{2}}=\frac{2.87 \times 10^{-2} \mathrm{~m}^{2} / \mathrm{s} \times 60 \mathrm{~s} \times 2.25}{112.5 \mathrm{~m}^{2}}=3.2 \times 10^{-4}$

$\begin{array}{ll}T & \text { transmissivity } \\ Q & \text { pumping rate } \\ S & \text { storativity } \\ \text { P } & \text { distence from the well to the piezometer } \\ \text { ds } & \text { drewdown per log cycle of time } \\ \text { b } & \text { intercept of the straight line } \\ & \text { with the zero-drawdown exis }\end{array}$

Figure 20. Determination of aquifer parameters with the Jacob-Semilog Method. After Fetter (1988). Time-drawdown data is from piezometer 1615-Z1 during the pumping test in hatchery well $\mathrm{H}-4$. 

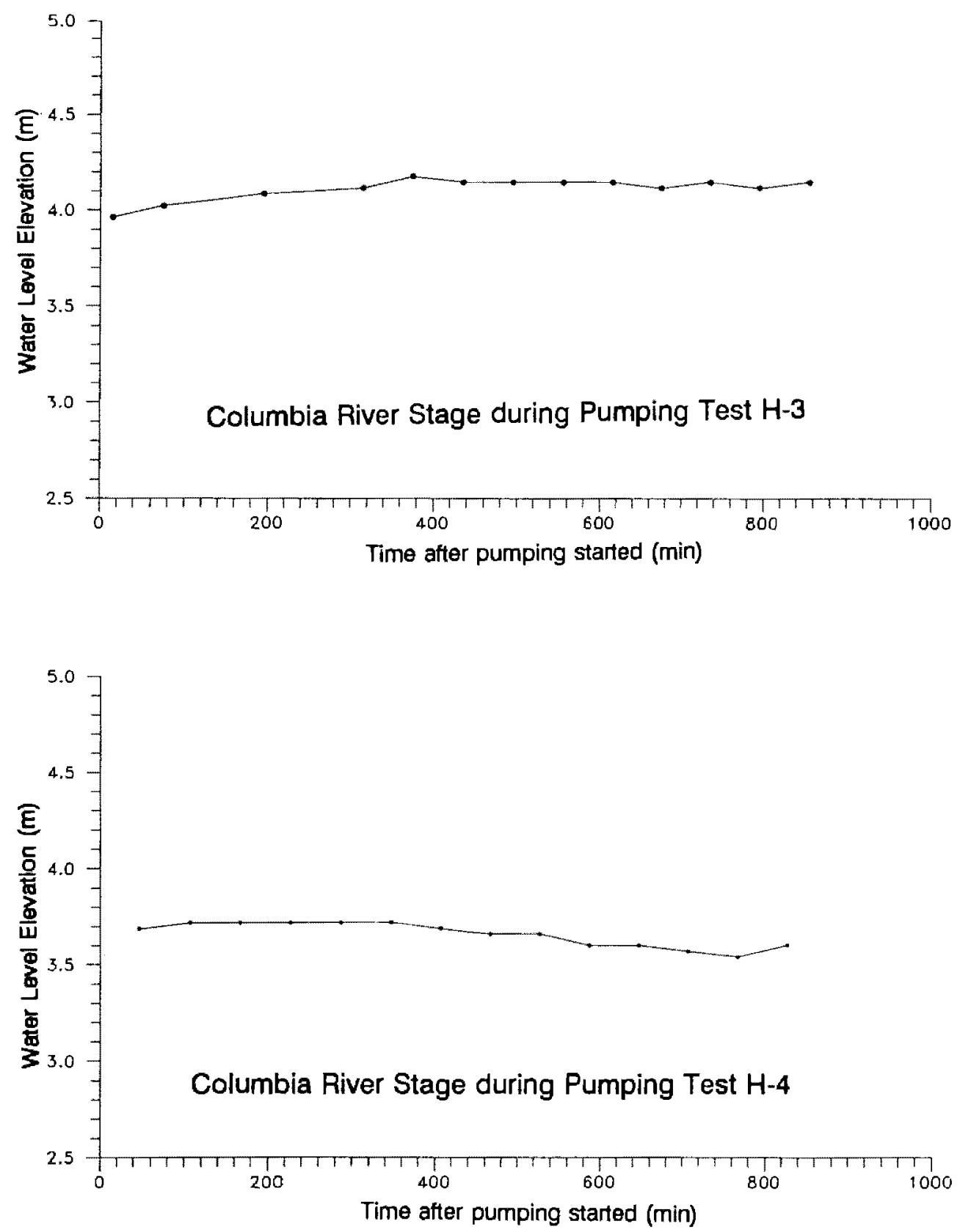

Figure 21. Columbia River stage during the pumping tests in wells $\mathrm{H}-3$ and $\mathrm{H}-4$. 


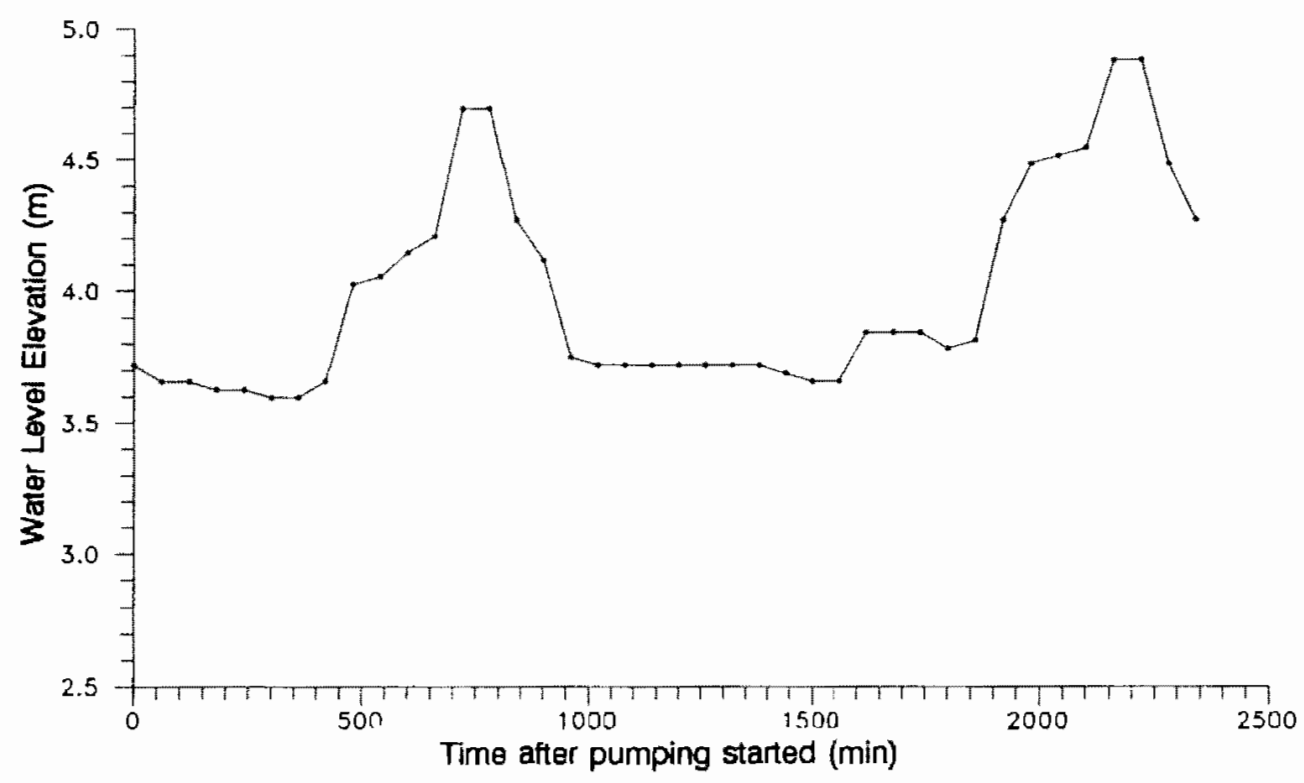

Figure 22. Columbia River stage during the pumping test in well A-2. 


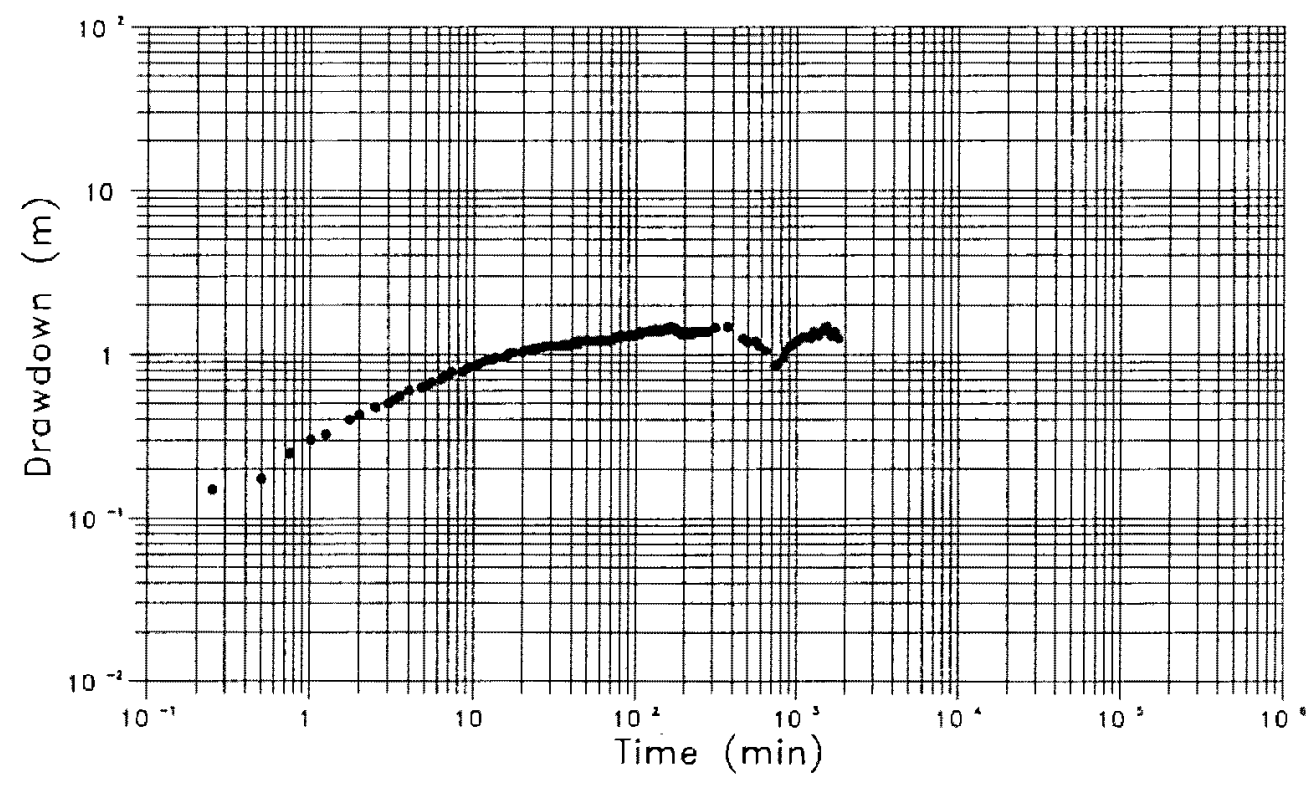

Figure 23. Pumping test A-2, time-drawdown plot for piezometer 1746-Z1. 


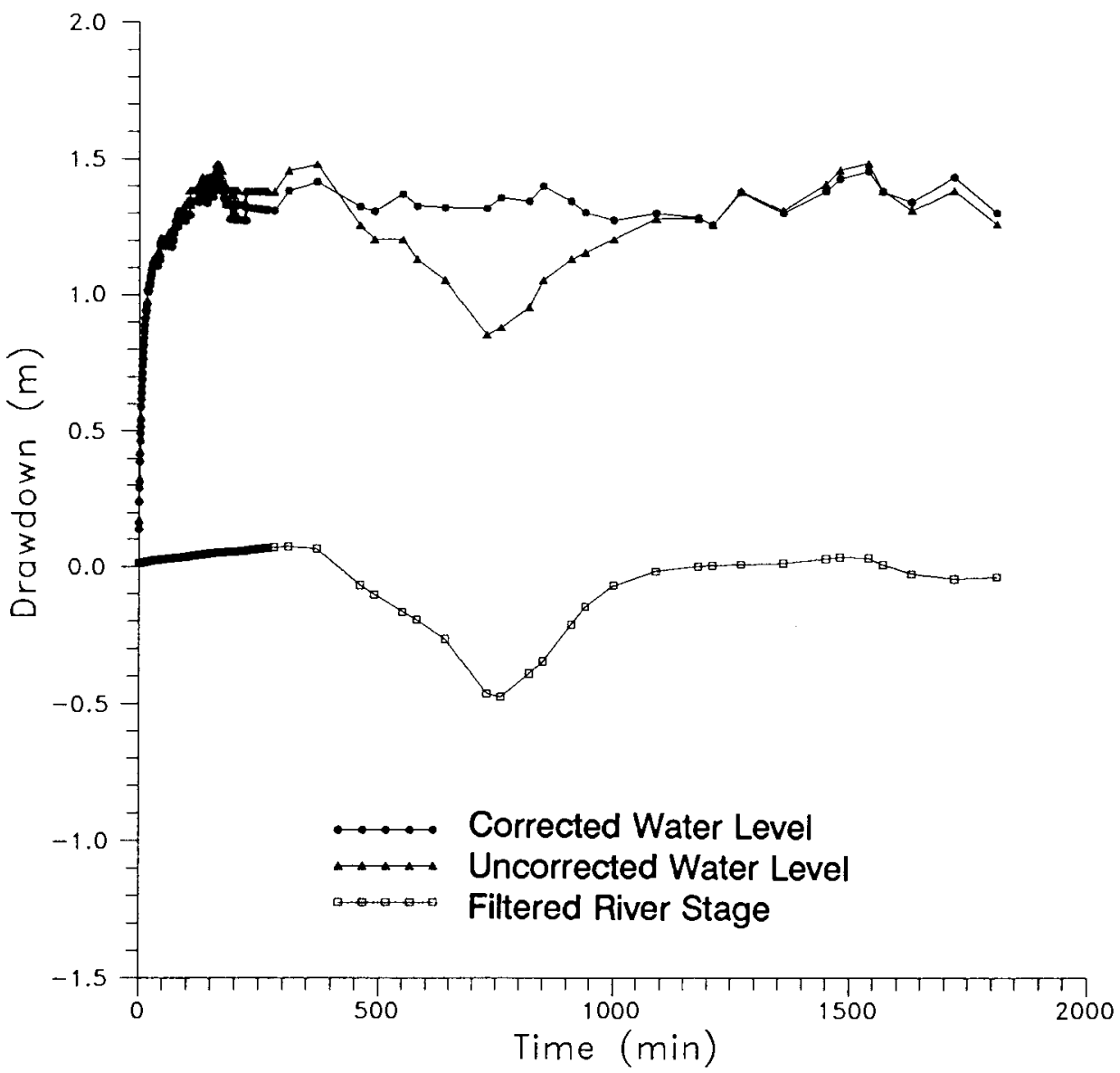

Filtering with the Leaky Integrator:

$\mathrm{E}=0.6 \quad$ Multiplication Factor $=0.5$

Figure 24. Correction of water level in piezometer $1746-\mathrm{Z} 1$ for the Columbia River stage fluctuation. 


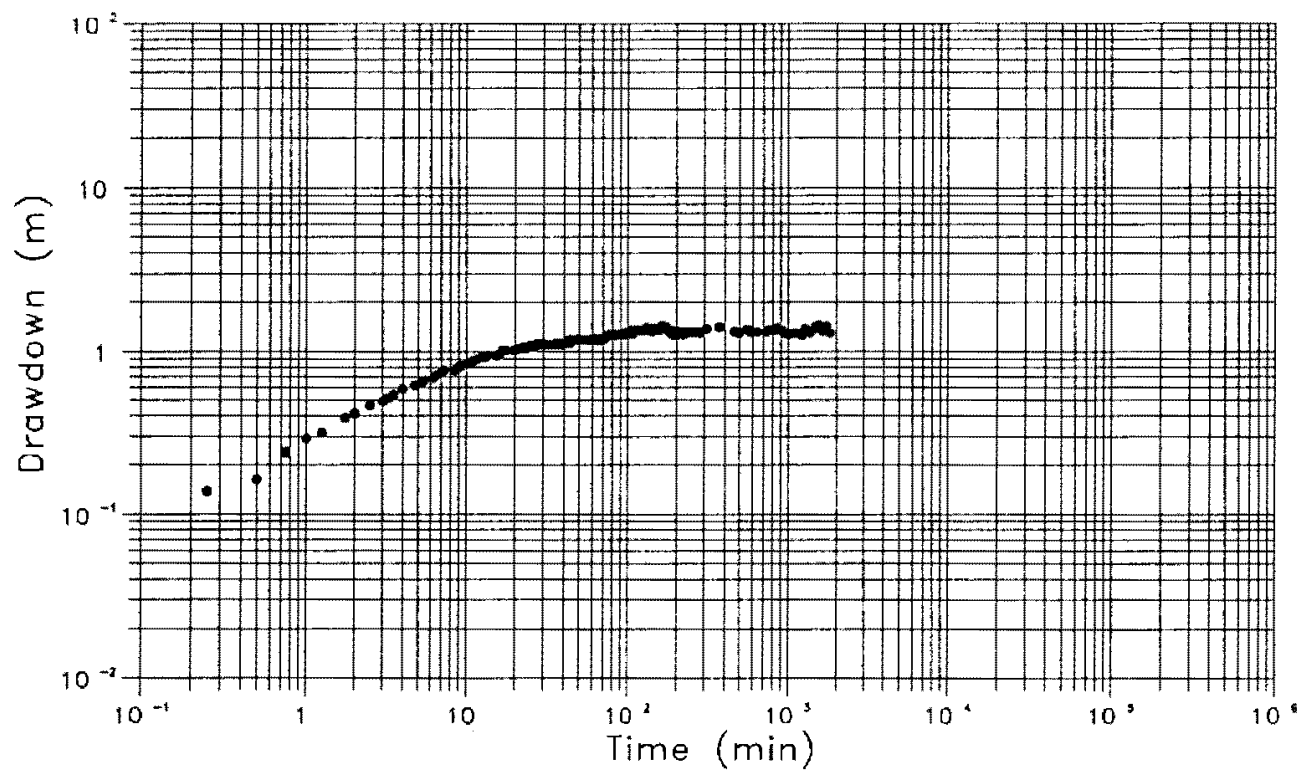

Figure 25. Water level in piezometer 1746-Z1 corrected for the influence of the Columbia River stage fluctuation. 


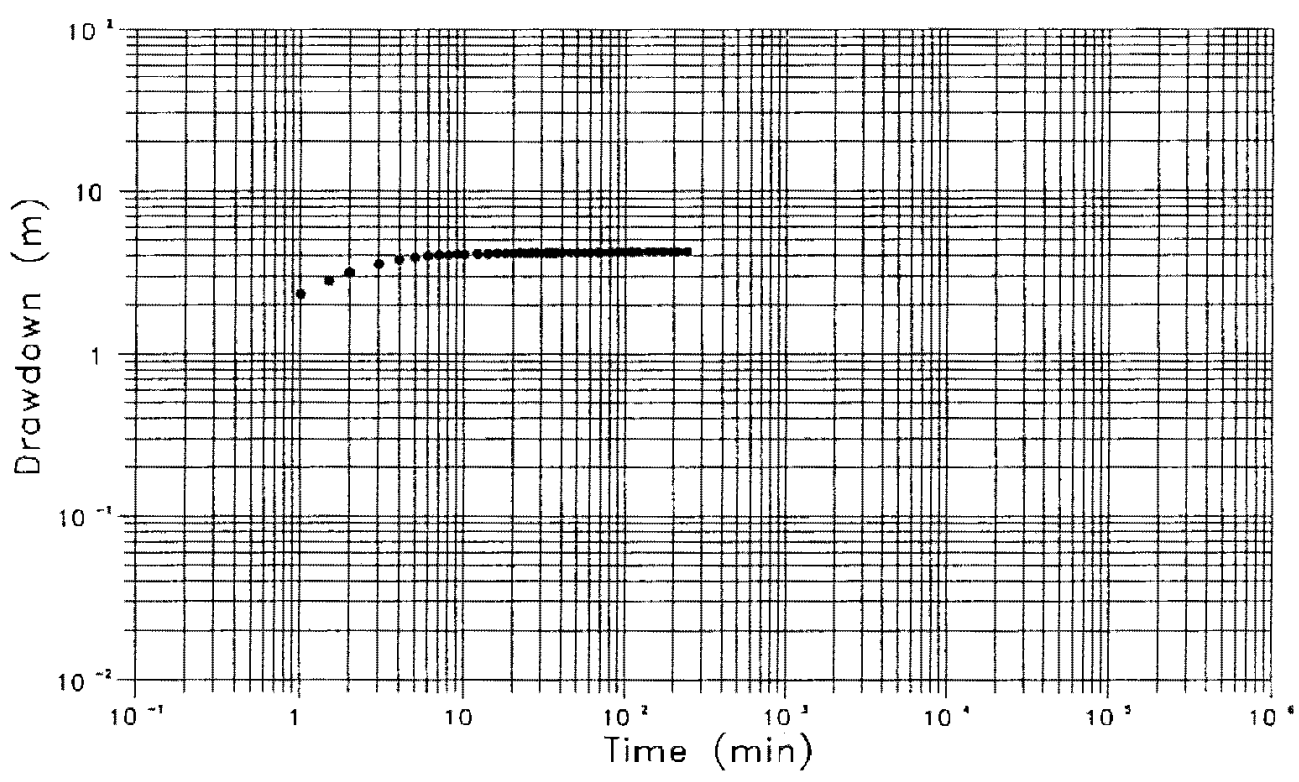

Pumping Test A-1, Test 1: Time-Drawdown Plot

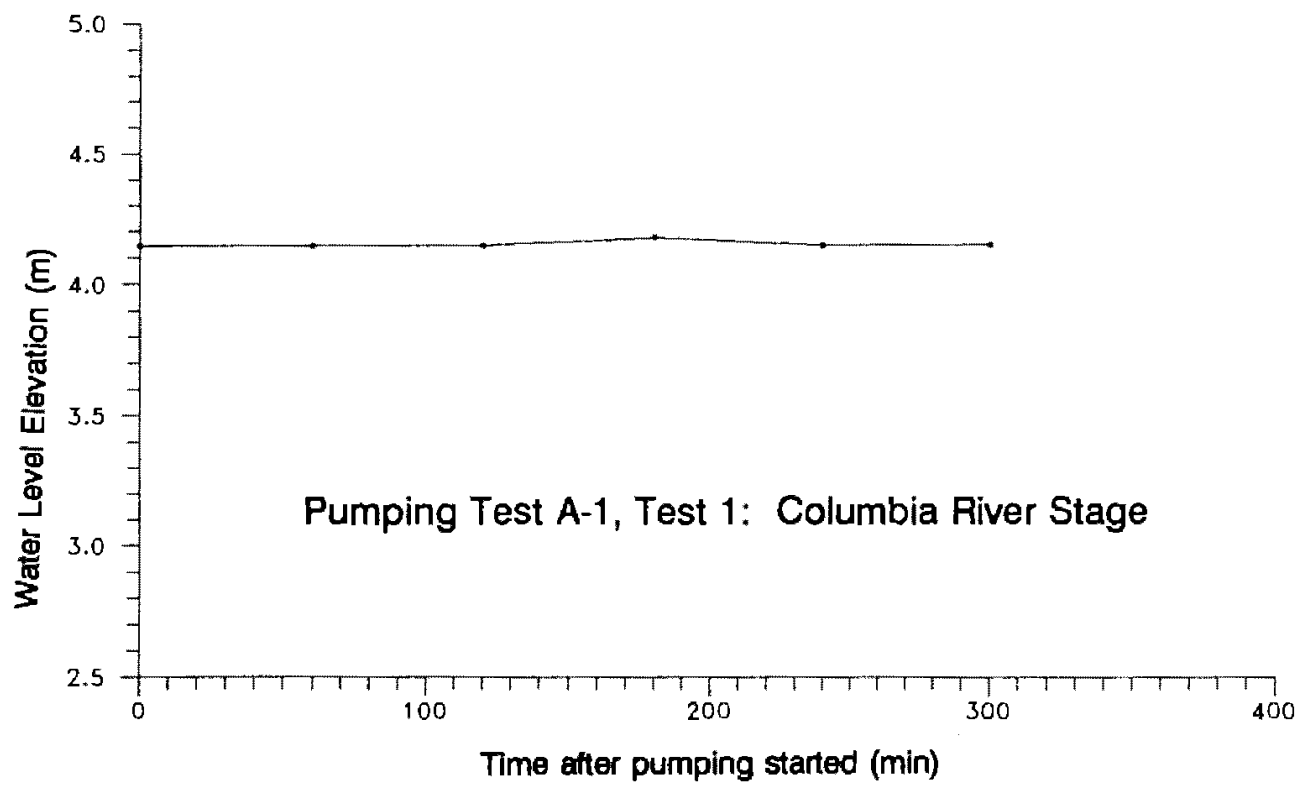

Figure 26. First pumping test in well A-1, time-drawdown plot and Columbia River stage. 


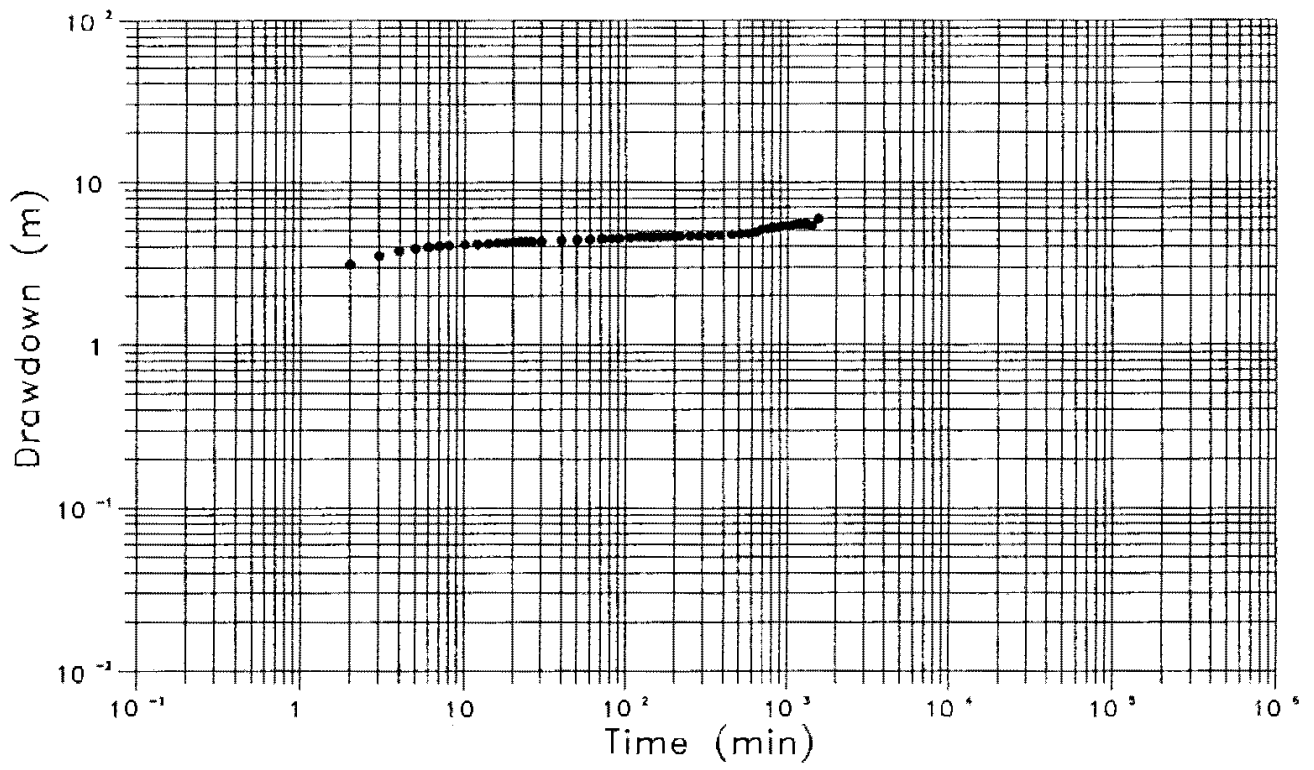

Pumping Test A-1, Test 2: Time-Drawdown Plot

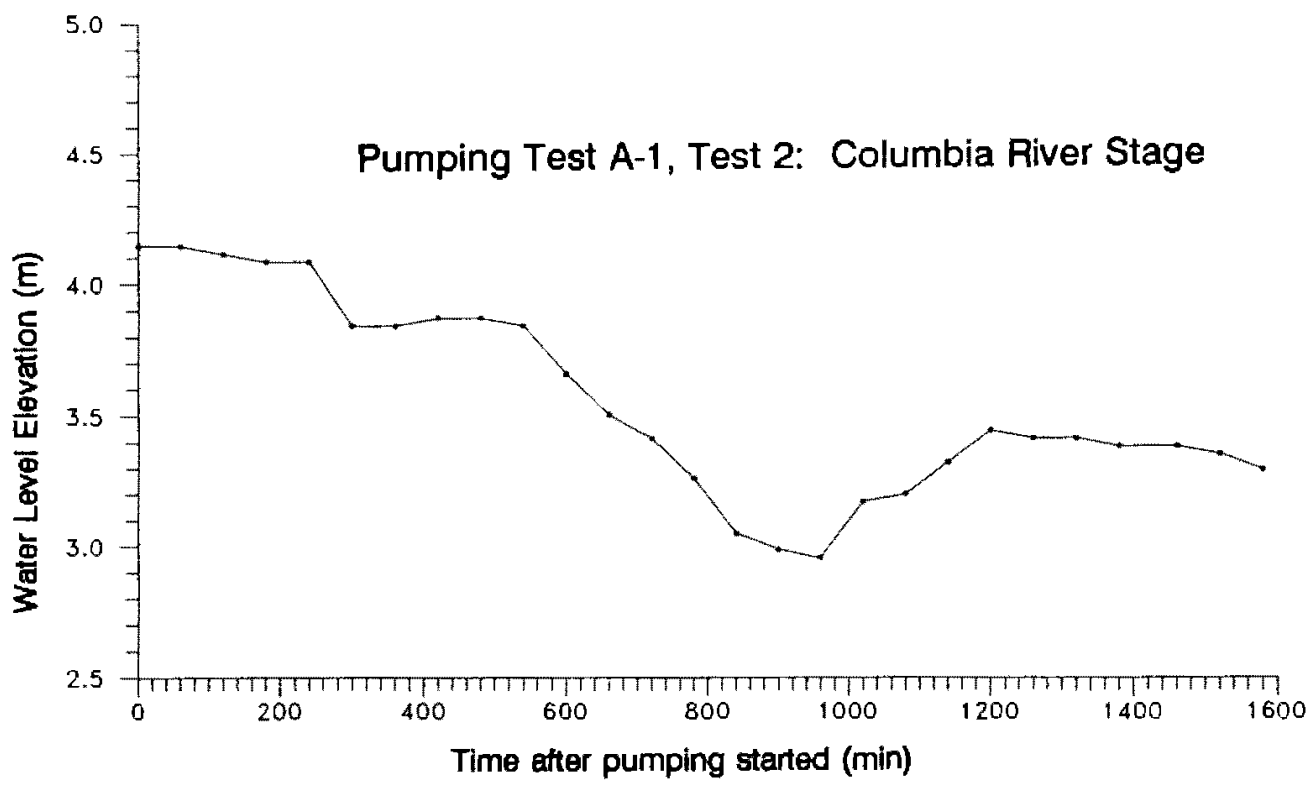

Figure 27. Second pumping test in well A-1, time-drawdown plot and Columbia River stage. 


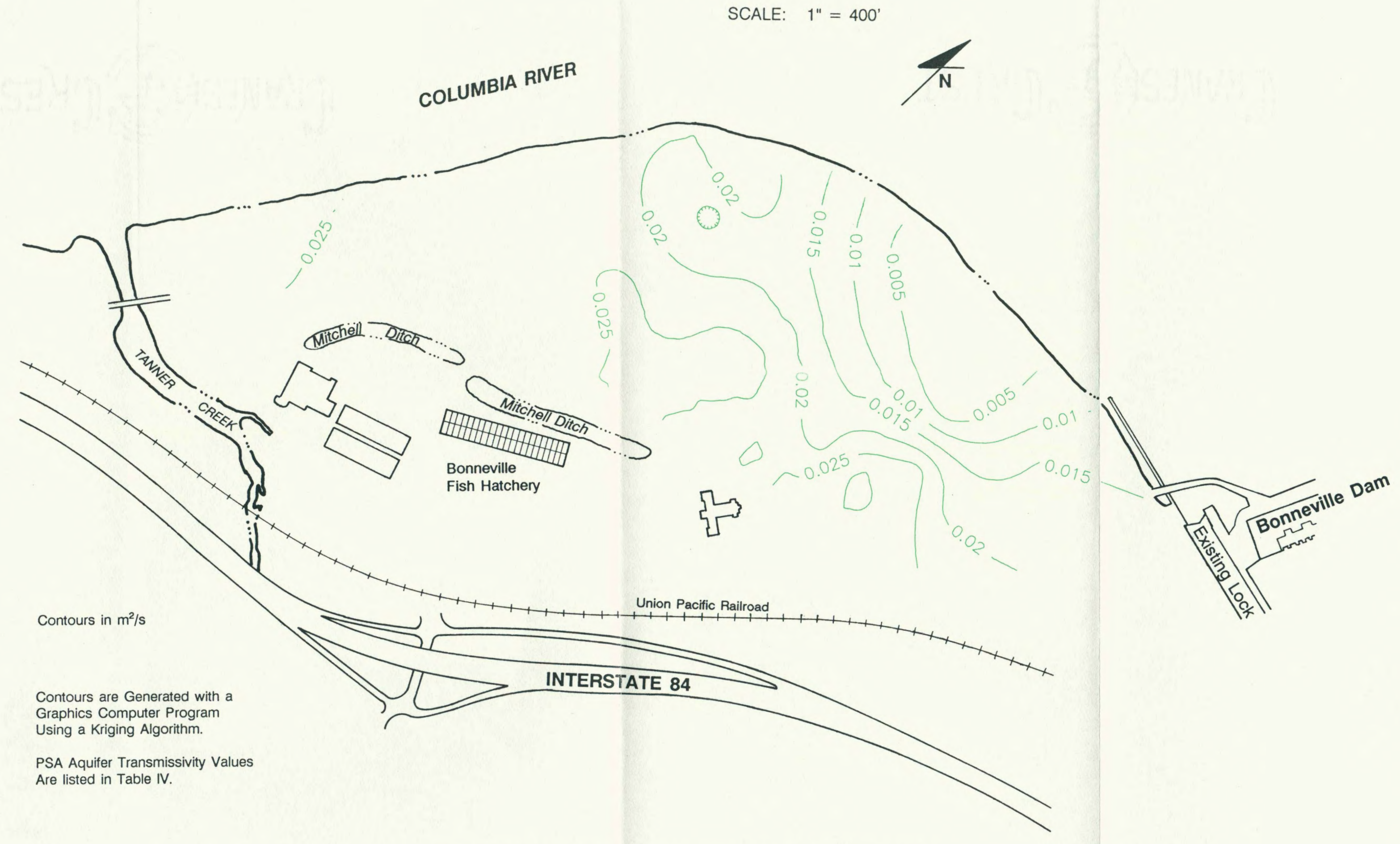




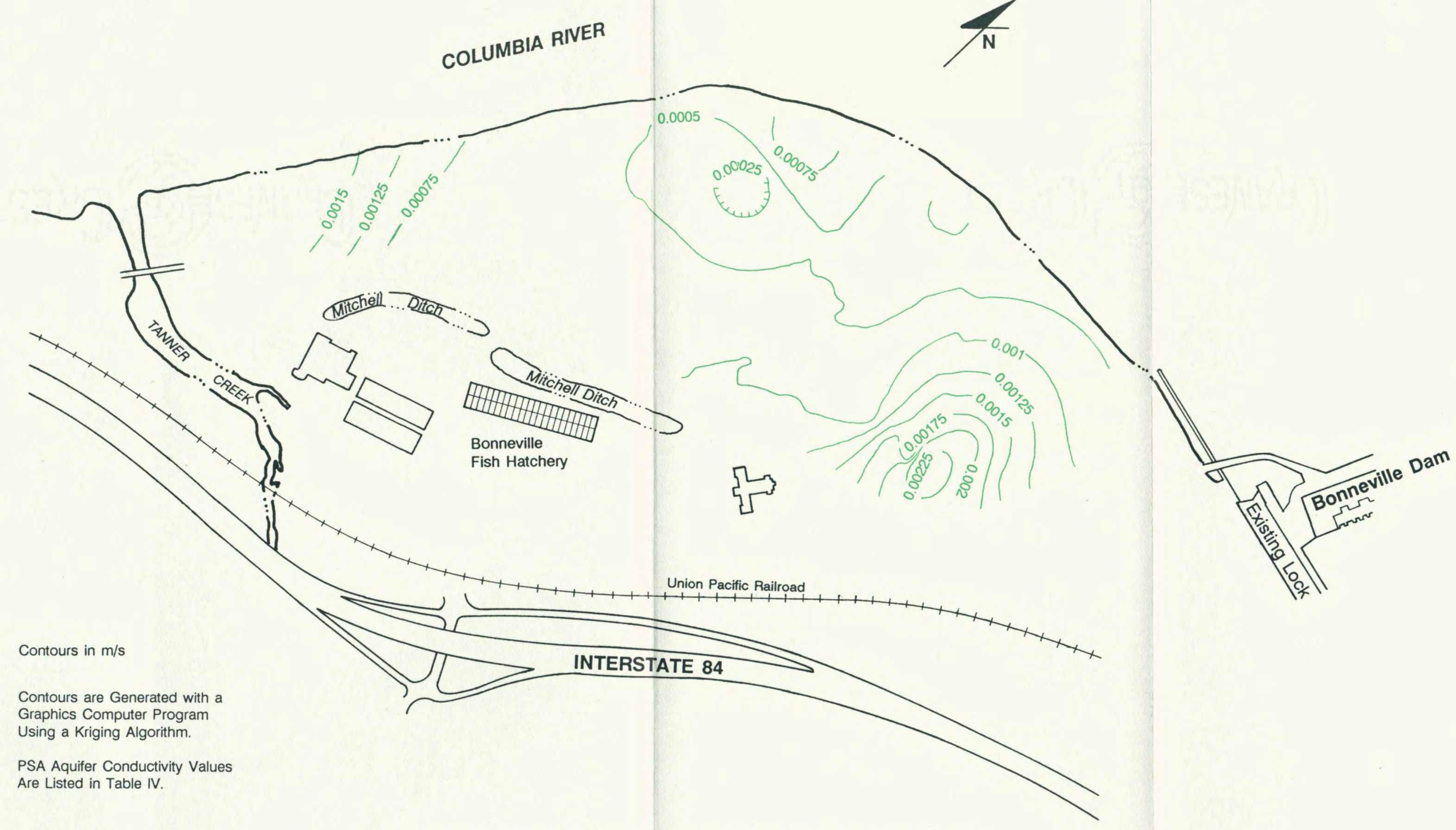

Figure 29. Areal distribution of hydraulic conductivity of the PSA aquifer. 


\section{CHAPTER IV}

\section{CONCEPTUAL MODEL OF THE GROUND WATER SYSTEM}

The main objectives of the first phase of the study were to develop a conceptual understanding of the system and to establish criteria to calibrate and test the performance of the computer model developed in the second phase.

\section{CONCEPTUALIZATION}

By combining all the available information about the geometry of the system, hydraulic properties of materials and boundary conditions, a conceptual model of the ground water system at the site can be developed.

Extent and properties of the four main hydrogeologic units, PSA aquifer, mica sand, b-unit and river deposits, determine the behavior of the system. The PSA aquifer, as the major water-bearing unit, is separated from the upper unconfined aquifer, the river deposits unit, by two aquitard layers, mica sand and b-unit. Results of the study indicate that the PSA aquifer is also effectively separated from the Columbia River by these layers that presumably extend below the river and possibly by fine-grained sediments on the bottom of the river channel. Direct recharge from the river into the PSA aquifer does not occur to a large extent. Instead recharge occurs over a large area by vertical leakage through the confining layers. The deposits overlying the PSA aquifer are in direct hydraulic connection to the river and receive recharge from it. The preferred direction of flow in the overlying alluvial 
deposits is horizontal due to their layered nature. Thin and locally distributed horizontal layers of fine material can restrict vertical flow considerably whereas the effect of such a layer on horizontal flow would be minimal.

Pumping in the PSA aquifer creates a large cone of depression which causes a hydraulic gradient between the aquifer and the overlying deposits. This gradient causes water to leak downward into the aquifer. Although the vertical hydraulic conductivity of the confining beds is low, the large area over which flow is induced supplies sufficient recharge to the PSA aquifer to constantly yield high quantities of water to wells. Water that leaks downward is replaced by water from the Columbia River that flows into the system horizontally through the confining layers and the highly transmissive river deposits that overlie mica sand and b-unit.

\section{CRITERIA FOR THE COMPUTER MODEL}

Having developed a conceptual understanding of the aquifer system, characteristic features of the system that should be reproduced by the computer model can be identified. Matching these observed features by the model is a criterion for the calibration of the model. The accuracy that can be achieved in matching these features will provides measure of the performance of the model.

The most useful set of information about the behavior of the ground water system is data from the pumping tests since detailed information about the system under stress is used for calibration. The fish hatchery pumping tests were be used for calibration since wells $\mathrm{H}-3$ and $\mathrm{H}-4$ lie directly in the proposed approach channel. Under the stress from pumping at a rate of $0.28 \mathrm{~m}^{3} / \mathrm{s}$ from the PSA aquifer the following reactions of the system were observed: 
1. in well $\mathrm{H}-3$ drawdowns of $4.9 \mathrm{~m}$ and $6.1 \mathrm{~m}$ occurred after 10 and 20 minutes of pumping; water level stabilized after 200 minutes with a total drawdown of $8 \mathrm{~m}$,

2. piezometers in the terrace area react almost instantaneously to the stress from pumping (less than 1 minute for piezometers close to the pumping well, up to five minutes for piezometers farther away),

3. drawdown in piezometers in the terrace area stabilizes after 200 minutes with a total drawdown between 2.5 and $4 \mathrm{~m}$,

4. drawdown is relatively uniform over the terrace area,

5. shallow piezometers in mica sand and b-unit respond to pumping in the PSA aquifer,

6. the cone of depression extends beyond the river; a change in the pumping rate of the well field of $0.22 \mathrm{~m}^{3} / \mathrm{s}$ results in a response starting 30 minutes after the change and with a total magnitude of about $0.3 \mathrm{~m}$ in piezometer $\mathrm{HI}-1$ on the Washington shore.

Plots of the observed pumping test data can be matched directly to calculated water levels at the piezometer locations.

Another independent set of conditions for testing the model is the steadystate head distribution in the PSA aquifer and in the upper unconfined aquifer under stress from simultaneous pumping in the hatchery well field and construction dewatering of river deposits, b-unit and upper mica sand. Detailed information about water levels and pumping rates is available in the instrumentation reports (L.R. Squier Associates, 1989). This set of conditions has the potential to characterize the interactions among the upper unconfined aquifer, aquitard layers and the PSA aquifer. 


\section{CHAPTER V}

\section{COMPUTER MODELING}

After determining the properties of the hydrogeologic units and developing a conceptual understanding of the ground water system, this information was integrated into the development of a computer model of the system. The model is a means of testing the validity of prior hydrogeologic analysis. If the model reproduces the observed features of the ground water system confidence is gained in the validity of the calculated parameters and the conceptual model of the system. The ground water modeling program HST3D (Heat and Solute Transport in 3 Dimensions) was chosen for the modeling. HST3D was developed by Kenneth L. Kipp, Jr. for the United States Geological Survey (Kipp, 1987). The FORTRAN code uses finitedifference techniques to simulate three-dimensional ground water flow with associated heat and solute transport. The program was run on an Amdahl mainframe computer and on an Intergraph Interserve 200 computer.

\section{DISCRETIZATION}

As the first step in the modeling effort, the geometry of the aquifer system, extent of hydrogeologic units with their respective properties, water wells, as well as boundary conditions and initial conditions were defined. 


\section{Model Geometry}

Prior analysis shows that the cone of depression from the fish hatchery wells is very large and that the influence from pumping in the hatchery well field extends beneath the Columbia River. The simulated area of the model has to be large enough to take that into account. An area of $1000 \mathrm{~m}$ by $1500 \mathrm{~m}$ including the downstream terrace area and extending beyond the Columbia River is covered by the model. The extent of the model grid and a view of the downstream terrace area with the overlay of the model grid are shown in Figures 30 and 31 . The model represents a thickness of $69 \mathrm{~m}$, corresponding approximately to the saturated thickness of the aquifer system in the downstream terrace area. The model is discretized into a grid of 23 by 17 by 9 deep nodes. An orthographic view of the three dimensional grid is shown in Figure 32. Grid spacing varies between 50 and $200 \mathrm{~m}$ in $\mathrm{x}$-and y-directions. Grid spacing is finer in the downstream terrace area where greater detail is required. Farther away the terrace grid spacing is coarser. In the z-direction, grid spacing varies between 5 and $12 \mathrm{~m}$, corresponding to average thicknesses of distinct stratigraphic units.

\section{Hydrogeologic Units}

Five different hydrogeologic units are included in the model. These are river deposits (RD), b-unit (BU), mica sand (MS), PSA aquifer (PSA), and a slide block embedded in the PSA aquifer in the northeastern part of the terrace. The extent of these units was assigned according to subsurface data from borings in the downstream terrace area. Extent of units under and beyond the Columbia River, where no subsurface data are available was extrapolated from conditions encountered in the downstream terrace area. A detailed depiction of the model layers 
showing the stratigraphic units assigned to different layers is presented in Appendix $\mathrm{C}$. Hydrogeologic properties were assigned to these units based on the results of pumping tests, laboratory tests, and general materials descriptions. During the model calibration, selected properties were modified in order to match observed water levels. Hydrogeologic properties that were assigned initially are summarized in Table VI. Hydraulic conductivity of bedrock underlying the sedimentary deposits and Bonney Rock intrusive in the east of the downstream terrace was considered to be negligible compared to the conductivity of the sedimentary units. A low hydraulic conductivity was assigned to bedrock and Bonney Rock intrusive, thus essentially excluding these from the simulation.

\section{Water Wells}

A total of twenty-four water wells are defined in the model. These wells represent existing hatchery wells, existing shallow dewatering wells, future hatchery wells, and future deep dewatering wells. Well locations and screened intervals are set according to existing or planned conditions. Table VII summarizes the well locations and screened intervals. Figure 33 shows the location of wells in the model grid. Pumping rates for new wells and other wells that were not used during the calibration were set to zero. In the future, pumping rates can be set to desired values.

\section{Boundary Conditions}

The Columbia River is represented by a set of specified pressure and temperature boundary condition nodes. Pressure, which corresponds to hydraulic head, and temperature at these nodes can be set according to river stages and temperatures that are to be simulated. Pressure and temperature at these cells can 
be changed during a simulation, thus making it possible to simulate long periods with changing river stage and temperature. The river channel extends to elevation $-12 \mathrm{~m}$ depth, in the model corresponding to the top of the mica sand unit. The river channel does not cut into the PSA aquifer in the model.

The proposed lock approach channel is simulated with specified temperature and pressure boundary condition nodes as well. The locations of boundary condition nodes representing Columbia River and approach channel are shown in Appendix C. These cells are included for future use, they were not used in the initial calibration process. The edges of the model are considered as no-flow boundaries.

\section{Initial Conditions}

Initially the model is set to a steady state condition with no wells operating. The steady state is defined by setting the initial hydraulic head to zero at elevation $5 \mathrm{~m}$ above mean sea level, corresponding to the initially defined Columbia River stage.

\section{SUMMMARY OF ASSUMPTIONS}

The computer model is based on the following assumptions:

1. Thickness, as well as elevation of top and bottom of distinct stratigraphic units, is set to a uniform value throughout the model. The values chosen correspond to average thickness and average elevation of stratigraphic units.

2. Stratigraphy under and beyond the Columbia River, where no subsurface data are available, is extrapolated from the stratigraphic units under the downstream terrace area. 
3. The Columbia River channel does not cut into the PSA aquifer. The PSA aquifer and river are separated by the confining mica sand unit throughout the model.

4. The underlying bedrock of the Weigle formation and Bonney Rock intrusive are considered to have very low hydraulic conductivity compared to the alluvial deposits, thus effectively excluding them from the simulation.

\section{GROUND WATER FLOW CALIBRATION}

After developing the geometry of the model and assigning hydrogeologic properties to distinct stratigraphic units, the next step was to calibrate the model for ground water flow. To accomplish the calibration and to verify the initial calibration, two independent sets of conditions were used.

\section{Calibration}

The first set of conditions for the calibration was a pumping test for fish hatchery well H-4 conducted on August 7, 1986 (Cornforth Consultants, Inc., 1987). Water levels observed during the pumping test are shown in Figures 34 through 40. Pumping rate for well $\mathrm{H}-4$ was set to $0.285 \mathrm{~m}^{3} / \mathrm{sec}$ corresponding to the pumping rate during the pumping test. The model was run for 1000 minutes, allowing the system to reach a steady state under the stress from pumping in well $\mathrm{H}-4$. Calculated water levels were observed and compared to water levels measured during the pumping test. Permeabilities of hydrogeologic units were varied within a range that appeared reasonable based on prior analysis in order to achieve the best match of observed and calculated water levels. Eight runs were completed and documented. Table VII lists the hydraulic conductivities that were tested in the different model runs. 
Verification

A second set of conditions was used to verify the parameters derived from the initial calibration. Water levels in shallow and deep piezometers, under given pumping rates in hatchery wells and shallow dewatering wells on September 12 , 1989, were used for the ground water flow verification. This particular date was chosen because relatively complete data are available from the automatic data acquisition system on that day. In addition, manual water level readings were made, thus providing a possibility to check the automatic readings. Furthermore, the river stage was relatively stable during that day so that water levels in the aquifer system were not disturbed by river level fluctuations. Pumping occurred from the hatchery wells in the PSA aquifer and from shallow dewatering wells. A match for both the shallow and the deep water levels with the model was attempted. This made it possible to evaluate the interaction between deep and shallow aquifer, a critical point for the evaluation of the effect of the future lock approach channel on the PSA aquifer. The water levels observed on September 12, 1989 are presented in Figures 41 and 42 . Water levels and pumping rates were taken from the bimonthly monitoring reports (L.R. Squier Associates, Inc., 1989). The procedure for the verification was to run both sets of conditions with the same hydrogeologic parameters for the different stratigraphic units. Then hydraulic conductivity of the PSA aquifer and the mica sand unit were varied and the scenarios were run again. Changes in water levels as a result of changed permeabilities were noted and the permeabilities that gave the best match of observed and calculated water levels for both scenarios were determined. It was found that horizontal hydraulic conductivity of the PSA aquifer and vertical hydraulic conductivity of the mica sand unit were the parameters that largely control 
water levels in the aquifer system. Table $\mathrm{X}$ summarizes permeabilities used in the different model runs. Permeabilities used in run HST195 and HST205 gave the best results for both tested sets of conditions. The results from these two simulations are presented in Figures 34 through 44 . Figures 34 through 40 show the simulation of pumping test $\mathrm{H}-4$. Figures 41 through 44 show results of the simulation of water levels on September 12, 1989. The hydrogeologic parameters used in these two simulation runs are summarized in Table $\mathrm{X}$.

\section{DISCUSSION}

Evaluation of the model runs for ground water flow calibration and verification, indicated that horizontal hydraulic conductivity of the PSA aquifer and vertical hydraulic conductivity of the mica sand unit were the two parameters that, to a large extent, control water levels in the aquifer system. Permeabilities of other hydrogeologic units appeared to have less influence. Values for hydrogeologic parameters determined from prior analysis and reported in this study and the values that give the best results in the model calibration and verification are very similar (Table $\mathrm{VI}$ and $\mathrm{X}$ ). The fact that no unrealistically large changes in hydrogeologic properties were necessary in order to achieve a satisfactory match of observed and calculated water levels, increases the confidence in the model calibration. The close match also supports the conceptual model and the assumptions on which the model was based. It appears that a continuous aquitard layer separating the PSA aquifer and the Columbia River is a valid representation of the river-aquifer system. 
TABLE VI

\section{PROPERTIES OF HYDROGEOLOGIC UNITS USED FOR INITIAL MODEL INPUT}

\begin{tabular}{|c|c|c|c|c|}
\hline Hydrogeologic Unit ${ }^{(1)}$ & $\begin{array}{l}\text { Hydraulic } \\
\text { Conductivity, } \\
\text { horizontal(2) } \\
{[\mathrm{m} / \mathrm{sec}]}\end{array}$ & $\begin{array}{l}\text { Hydraulic } \\
\text { Conductivity, } \\
\text { vertical(2) } \\
{[\mathrm{m} / \mathrm{sec}]}\end{array}$ & Storativity & Porosity \\
\hline River Deposits (RD) & $1 * 10^{-2}$ & $1 * 10^{-3}$ & $2 \star 10^{-10}$ & 0.45 \\
\hline B-Unit (BU) & $4.7^{\star} \times 10^{-6}$ & $4.7^{*} 10^{-6}$ & $1 * 10^{-8}$ & 0.36 \\
\hline Mica Sand (MS) & $7^{\star} 10^{-5}$ & $3^{\star} 10^{-8}$ & $1 * 10^{-8}$ & 0.36 \\
\hline PSA Aquifer (PSA) & $1.6^{\star} 10^{-3}$ & $1 * 10^{-3}$ & $2 * 10^{-10}$ & 0.40 \\
\hline Slide Block & $4.9 * 10^{-5}$ & $9.7^{\star}+10^{-6}$ & $2 \star 10^{-10}$ & 0.40 \\
\hline
\end{tabular}

(1) Refer to Appendix C for the extent of hydrogeologic units in the model.

(2) The actual input parameter for the model is intrinsic permeability $\left[\mathrm{m}^{2}\right]$, which takes the temperature dependent fluid viscosity and density into account.

Conversion from intrinsic permeability $\left(K_{i}\right)$ to hydraulic conductivity $(K)$ at $10^{\circ} \mathrm{C}$ :

$$
K_{1}=K * 1.34 * 10^{-7} m^{\star} \sec
$$




\section{TABLE VII}

WATER WELLS INCLUDED IN THE COMPUTER MODEL

Water Well Number

Grid Location (1)

Screened Interval Elevation

[m above MSL]

Existing Hatchery Wells:

$\begin{array}{lll}\text { H-1 } & 7 / 15 & -28 /-40 \\ H-2 & 7 / 14 & -28 /-40 \\ H-3 & 7 / 13 & -28 /-40 \\ H-4 & 7 / 12 & -28 /-40 \\ H-5 & 8 / 11 & -28 /-40 \\ W W-1794 & 10 / 11 & -28 /-40 \\ W W-1800 & 11 / 7 & -28 /-40 \\ F-1 & 10 / 12 & -28 /-40\end{array}$

Existing Shallow Dewatering Wells:

$\begin{array}{lll}\text { SW-11 } & 5 / 4 & 0 /-12 \\ \text { SW-12 } & 5 / 5 & 0 /-12 \\ \text { SW-13 } & 5 / 8 & 0 /-12 \\ \text { SW-14 } & 8 / 2 & 0 /-12 \\ \text { SW-15 } & 8 / 3 & 0 /-12 \\ \text { SW-16 } & 9 / 4 & 0 /-12 \\ \text { SW-17 } & 9 / 5 & 0 /-12 \\ \text { SW-18 } & 9 / 7 & 0 /-12\end{array}$

Future Deep Dewatering Wells:

$\begin{array}{llr}\text { DW-9 } & 11 / 8 & -28 /-40 \\ \text { DW-10 } & 11 / 9 & -28 /-40\end{array}$

Future Hatchery Wells:

$\begin{array}{lll}\text { F-2 } & 9 / 11 & -28 /-40 \\ \text { F-3 } & 9 / 9 & -28 /-40 \\ \text { F-5 } & 9 / 10 & -28 /-40 \\ \text { F-6 } & 11 / 12 & -28 /-40 \\ \text { F-7 } & 9 / 8 & -28 / 40 \\ \text { F-8 } & 9 / 6 & -28 /-40\end{array}$

(1) $\mathrm{X}$ - and $\mathrm{Y}$-coordinates on the model grid are shown in Figure 33. 
TABLE VIII

\section{HORIZONTAL AND VERTICAL HYDRAULIC CONDUCTIVITIES USED IN MODEL RUNS SIMULATING PUMPING TEST H-4}

Hydrogeologic Unit'

Hydraulic Conductivity $[\mathrm{m} / \mathrm{sec}]^{\text {a }}$

Initial HST174 HST175 HST176 HST177 HST178 HST179 HST1710 HST1711 Estimate $^{(3)}$

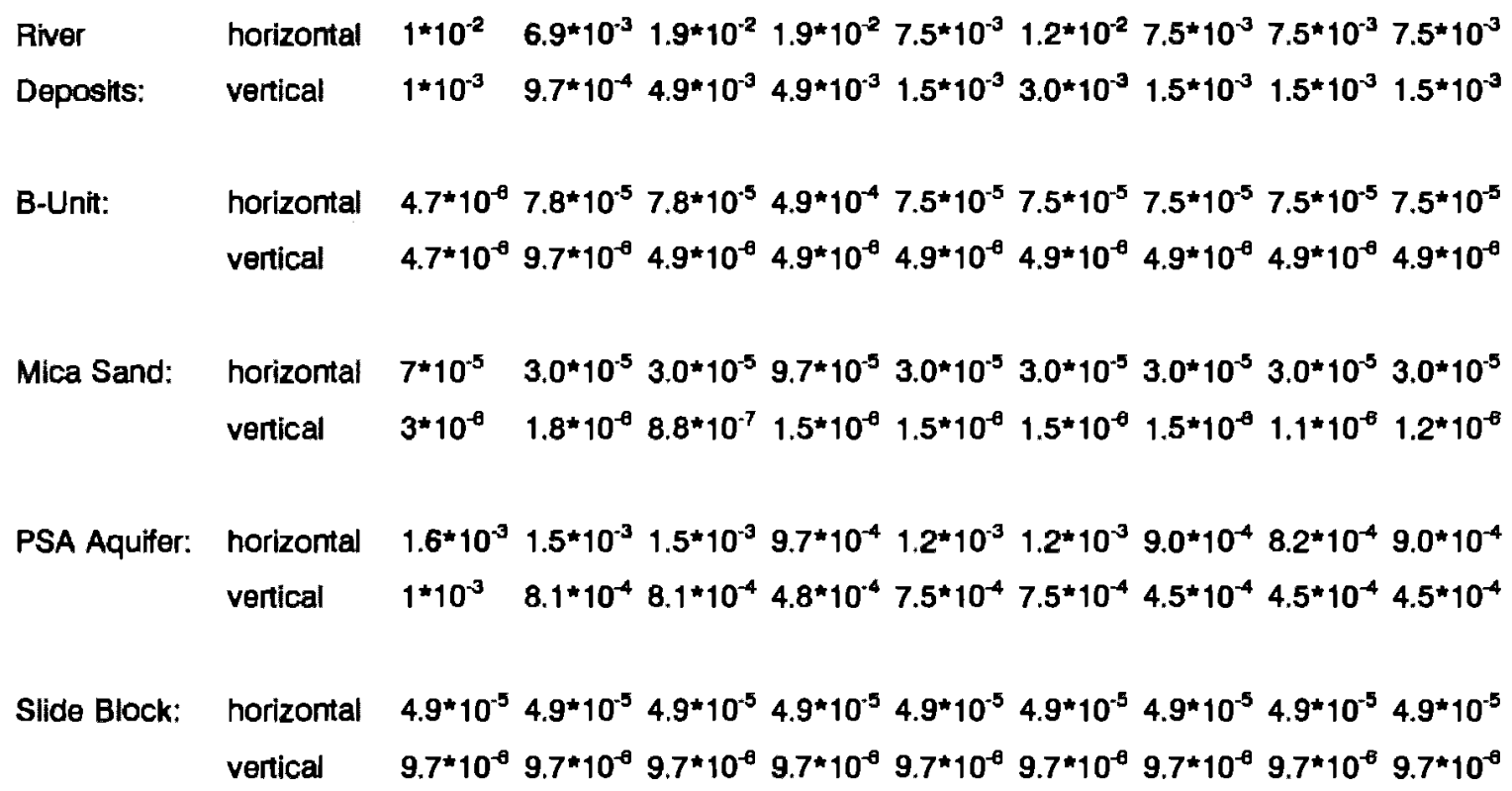

(1) Refer to Appendix $\mathrm{C}$ for the extent of hydrogeologic units in the model.

(2) The actual input parameter for the model is intrinsic permeability $\left[\mathrm{m}^{2}\right]$, which takes the temperature dependent fluid viscosity and density into account.

Conversion from intrinsic permeability $\left(K_{i}\right)$ to hydraulic conductivity $(K)$ at $10^{\circ} \mathrm{C}$ :

$$
K_{1}=K \star 1.34^{\star} 10^{-7} \mathrm{~m}^{\star} \mathrm{sec}
$$

(3) Inital estimates of porous medium permeabilities of the different hydrogeologic units were based on pumping test analysis, laboratory tests and general material descriptions. 
TABLE IX

HYDRAULIC CONDUCTIVITIES USED IN GROUND WATER FLOW CALIBRATION AND VERIFICATION MODEL RUNS ${ }^{(1)}$

Hydrogeologic Unim

Hydraulic Conductivity $[\mathrm{m} / \mathrm{sec}]^{\text {a) }}$

$\begin{array}{lllll}\text { HST191 } & \text { HST192 } & \text { HST193 } & \text { HST194 } & \text { HST195 } \\ \text { HST201 } & \text { HST202 } & \text { HST203 } & \text { HST204 } & \text { HST205 }\end{array}$

\begin{tabular}{|c|c|c|c|c|c|c|}
\hline River Deposits: & $\begin{array}{l}\text { horizontal } \\
\text { vertical }\end{array}$ & $\begin{array}{l}7.5^{\star} 10^{-3} \\
1.5^{\star} 10^{-3}\end{array}$ & $\begin{array}{l}7.5^{\star} 10^{-3} \\
1.5 * 10^{-3}\end{array}$ & $\begin{array}{l}7.5^{\star} 10^{-3} \\
1.5^{\star} 10^{-3}\end{array}$ & $\begin{array}{l}7.5^{\star} 10^{-3} \\
1.5^{\star} 10^{-3}\end{array}$ & $\begin{array}{l}7.5^{\star} 10^{-3} \\
1.5^{\star} 10^{-3}\end{array}$ \\
\hline B-Unit: & $\begin{array}{l}\text { horizontal } \\
\text { vertical }\end{array}$ & $\begin{array}{l}7.5^{*} 10^{-5} \\
4.9 * 10^{-6}\end{array}$ & $\begin{array}{l}7.5^{*} 10^{-5} \\
4.9 * 10^{-8}\end{array}$ & $\begin{array}{l}7.5^{*} 10^{-5} \\
4.9 * 10^{-8}\end{array}$ & $\begin{array}{l}7.5^{*} 10^{-5} \\
4.9^{*} 10^{-8}\end{array}$ & $\begin{array}{l}7.5^{\star} 10^{-5} \\
4.9 * 10^{-8}\end{array}$ \\
\hline Mica Sand: & $\begin{array}{l}\text { horizontal } \\
\text { vertical }\end{array}$ & $\begin{array}{l}2.9^{*} 10^{-5} \\
1.5^{*} 10^{-7}\end{array}$ & $\begin{array}{l}2.9 * 10^{-5} \\
7.8^{*} 10^{-7}\end{array}$ & $\begin{array}{l}2.9^{*} 10^{-5} \\
1.5 * 10^{-6}\end{array}$ & $\begin{array}{l}2.9 * 10^{-5} \\
1.5 * 10^{-9}\end{array}$ & $\begin{array}{l}2.9 * 10^{-5} \\
1.5^{\star} 10^{-8}\end{array}$ \\
\hline PSA Aquifer: & $\begin{array}{l}\text { horizontal } \\
\text { vertical }\end{array}$ & $\begin{array}{l}9.0^{\star} 10^{-4} \\
4.5^{\star} 10^{-4}\end{array}$ & $\begin{array}{l}9.0^{*} 10^{-3} \\
4.5^{\star} 10^{-4}\end{array}$ & $\begin{array}{l}9.0^{*} 10^{-3} \\
4.5^{\star} 10^{-4}\end{array}$ & $\begin{array}{l}1.8^{\star} 10^{-3} \\
4.5^{\star} 10^{-4}\end{array}$ & $\begin{array}{l}1.3^{\star} 10^{-3} \\
4.5^{\star} 10^{-4}\end{array}$ \\
\hline Slide Block: & $\begin{array}{l}\text { horizontal } \\
\text { vertical }\end{array}$ & $\begin{array}{l}4.9 * 10^{-5} \\
9.7 * 10^{-6}\end{array}$ & $\begin{array}{l}4.9 * 10^{-5} \\
9.7 * 10^{-8}\end{array}$ & $\begin{array}{l}4.9 * 10^{-5} \\
9.7 * 10^{-6}\end{array}$ & $\begin{array}{l}4.9 * 10^{-5} \\
9.7^{\star} 10^{-6}\end{array}$ & $\begin{array}{l}4.9 * 10^{-5} \\
9.7 * 10^{-8}\end{array}$ \\
\hline
\end{tabular}

(1) Runs HST191, HST192, HST193, HST194 and HST195 are simulations of the pumping test in well H-4. Runs HST201, HST202, HST203, HST204 and HST205 are simulations of the steady state head distribution on September 12, 1989.

(2) Refer to Appendix $\mathrm{C}$ for the extent of hydrogeologic units in the model.

(3) The actual input parameter for the model is intrinsic permeability $\left[\mathrm{m}^{2}\right]$, which takes the temperature dependent fluid viscosity and density into account.

Conversion from intrinsic permeability $\left(K_{1}\right)$ to hydraulic conductivity $(K)$ at $10^{\circ} \mathrm{C}$ :

$$
K_{1}=K * 1.34 * 10^{-7} m^{*} \sec
$$


TABLE $X$

\section{PROPERTIES OF HYDROGEOLOGIC UNITS ASSIGNED AFTER MODEL CALIBRATION AND VERIFICATION}

Hydrogeologic Unit ${ }^{(1)}$

$$
\begin{aligned}
& \text { Hydraulic } \\
& \text { Conductivity, } \\
& \text { horizontal( }{ }^{(2)} \\
& {[\mathrm{m} / \mathrm{sec}]}
\end{aligned}
$$

$$
\begin{aligned}
& \text { Hydraulic } \\
& \text { Conductivity, } \\
& \text { vertical|(2) } \\
& {[\mathrm{m} / \mathrm{sec}]}
\end{aligned}
$$

Storativity

Porosity

\begin{tabular}{lllll} 
River Deposits (RD) & $7.5^{\star} 10^{-3}$ & $1.5^{\star} 10^{-3}$ & $2 \star 10^{-10}$ & .45 \\
B-Unit (BU) & $7.5^{\star} 10^{-5}$ & $4.9 * 10^{-8}$ & $1 * 10^{-8}$ & .36 \\
Mica Sand (MS) & $2.9 \star 10^{-5}$ & $1.5^{\star} 10^{-6}$ & $1 \star 10^{-8}$ & .36 \\
PSA Aquifer (PSA) & $1.3^{\star} 10^{-3}$ & $4.5^{\star} 10^{-4}$ & $2 \star 10^{-10}$ & .40 \\
Slide Block & $4.9 * 10^{-5}$ & $9.7^{\star} 10^{-6}$ & $2 \star 10^{-10}$ & .40 \\
\hline
\end{tabular}

(1) Refer to Appendix C for the extent of hydrogeologic units in the model.

(2) The actual input parameter for the model is intrinsic permeability $\left[\mathrm{m}^{2}\right]$, which takes the temperature dependent fluid viscosity and density into account.

Conversion from intrinsic permeability $(K)$ to hydraulic conductivity $(K)$ at $10^{\circ} \mathrm{C}$ :

$$
K_{1}=K * 1.34 * 10^{-7} \mathrm{~m} * \mathrm{sec}
$$




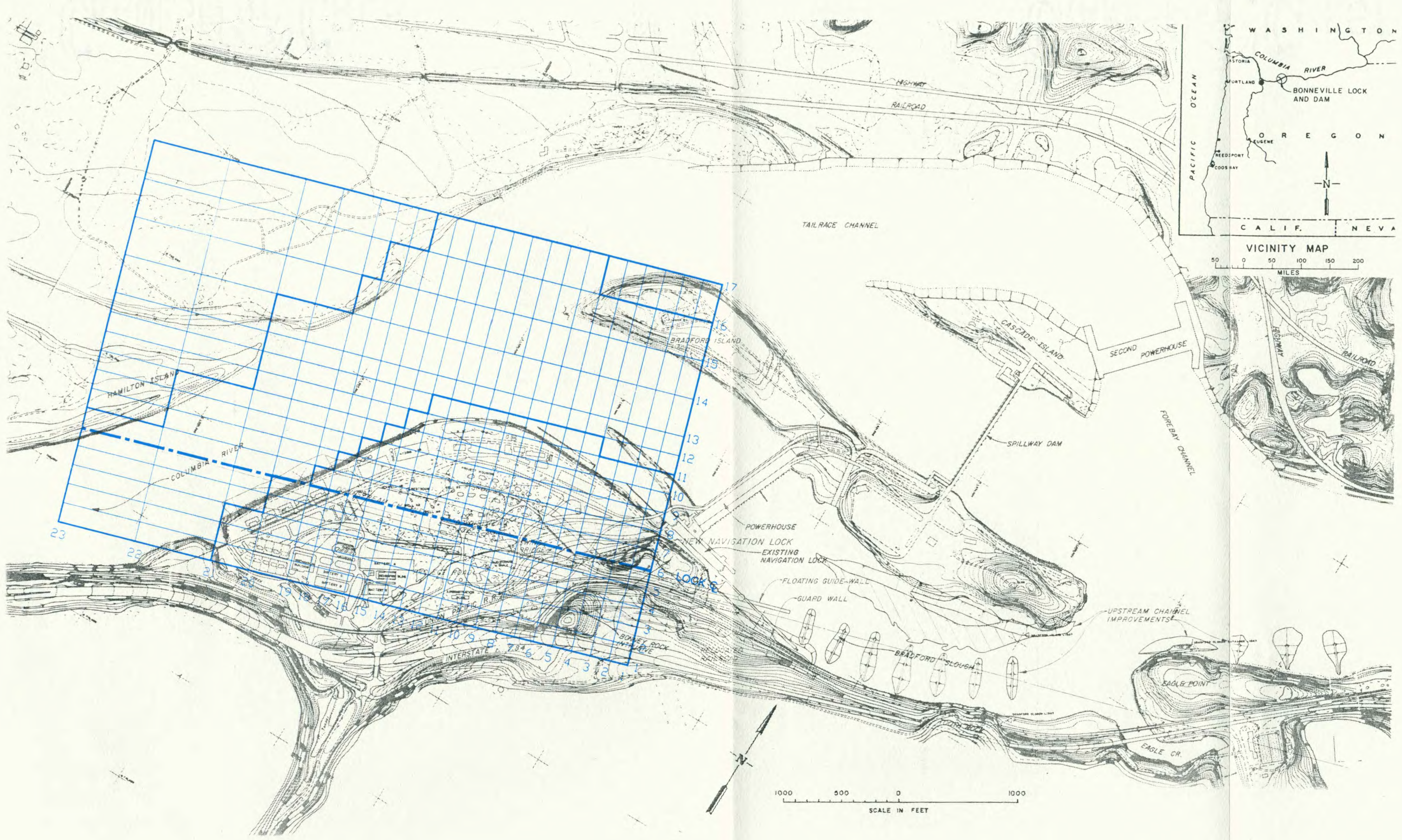




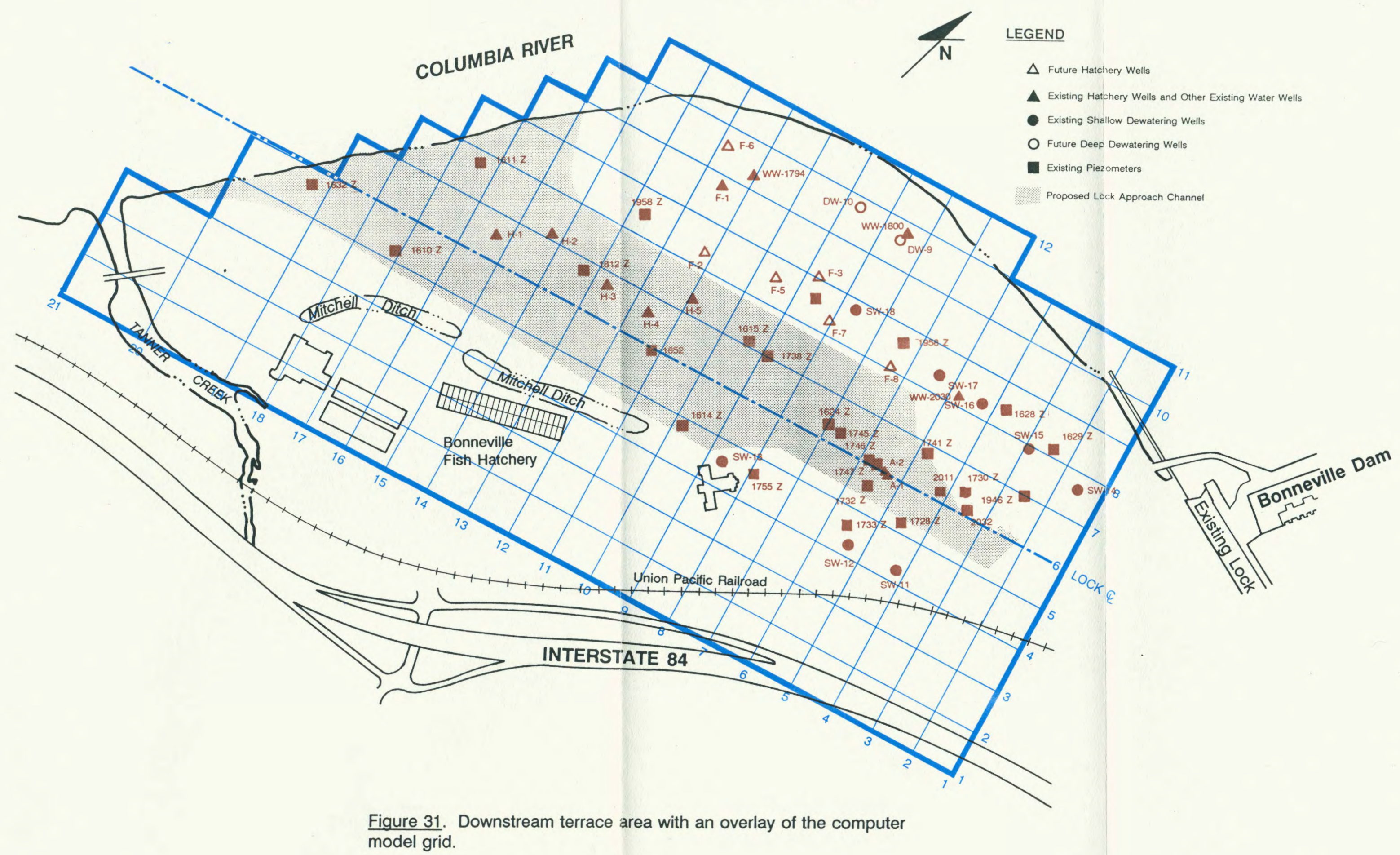



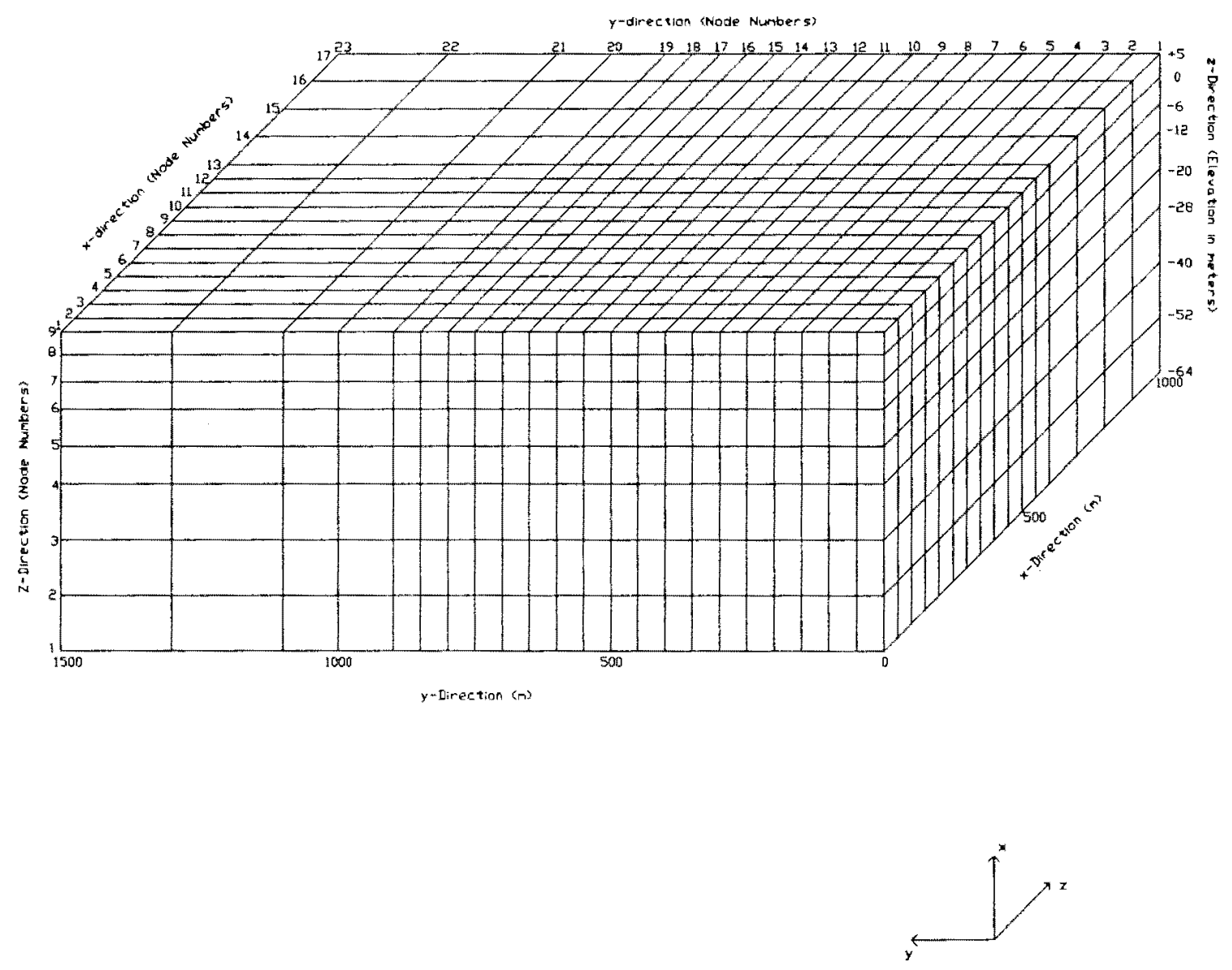

Figure 32. View of the three-dimensional computer model grid. 
$y$-Direction $(m)$

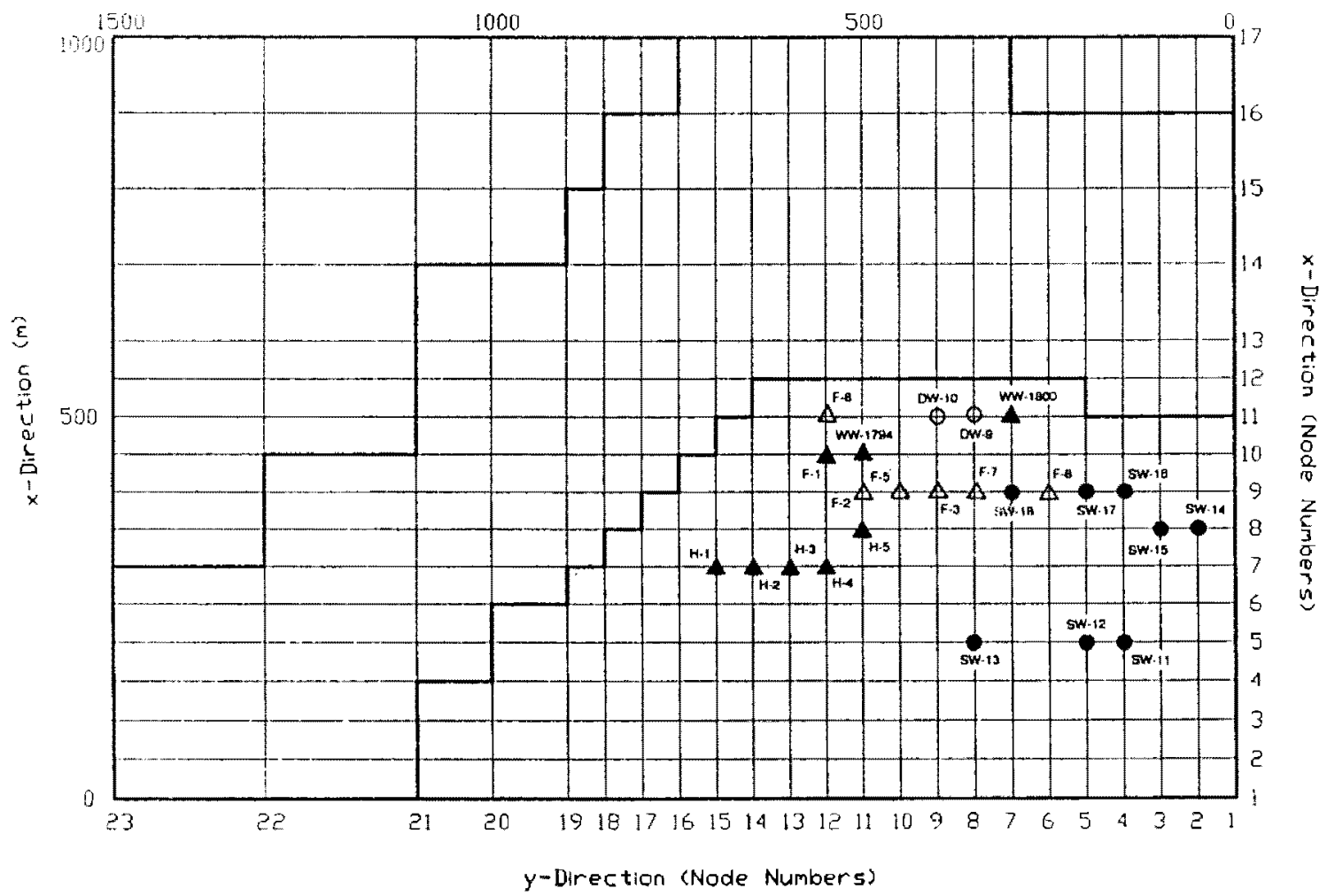

Figure 33. Top view of the computer model grid. 


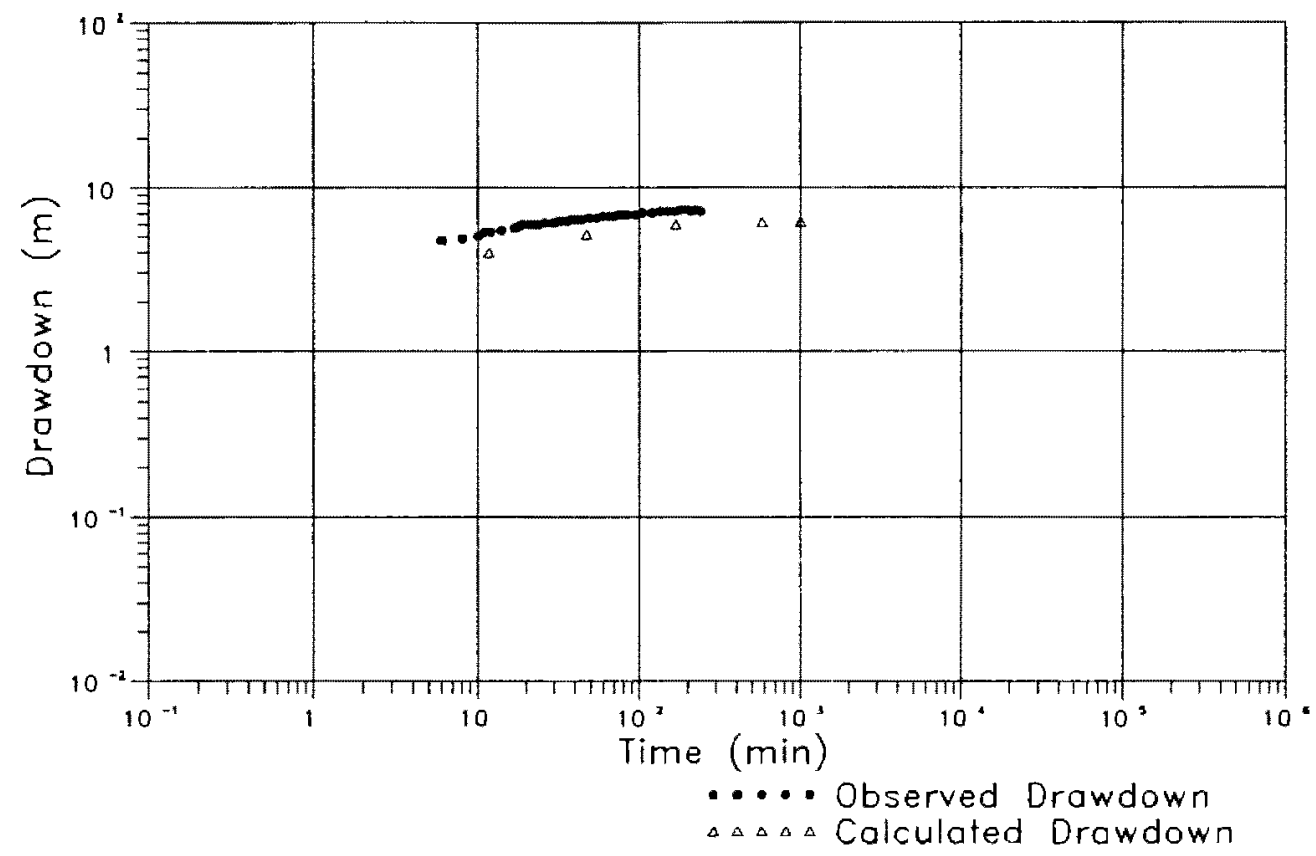

Calculated Data is from Model Run HST205

Figure 34. Results of simulation of pumping test $\mathrm{H}-4$ : water well $\mathrm{H}-4$ 


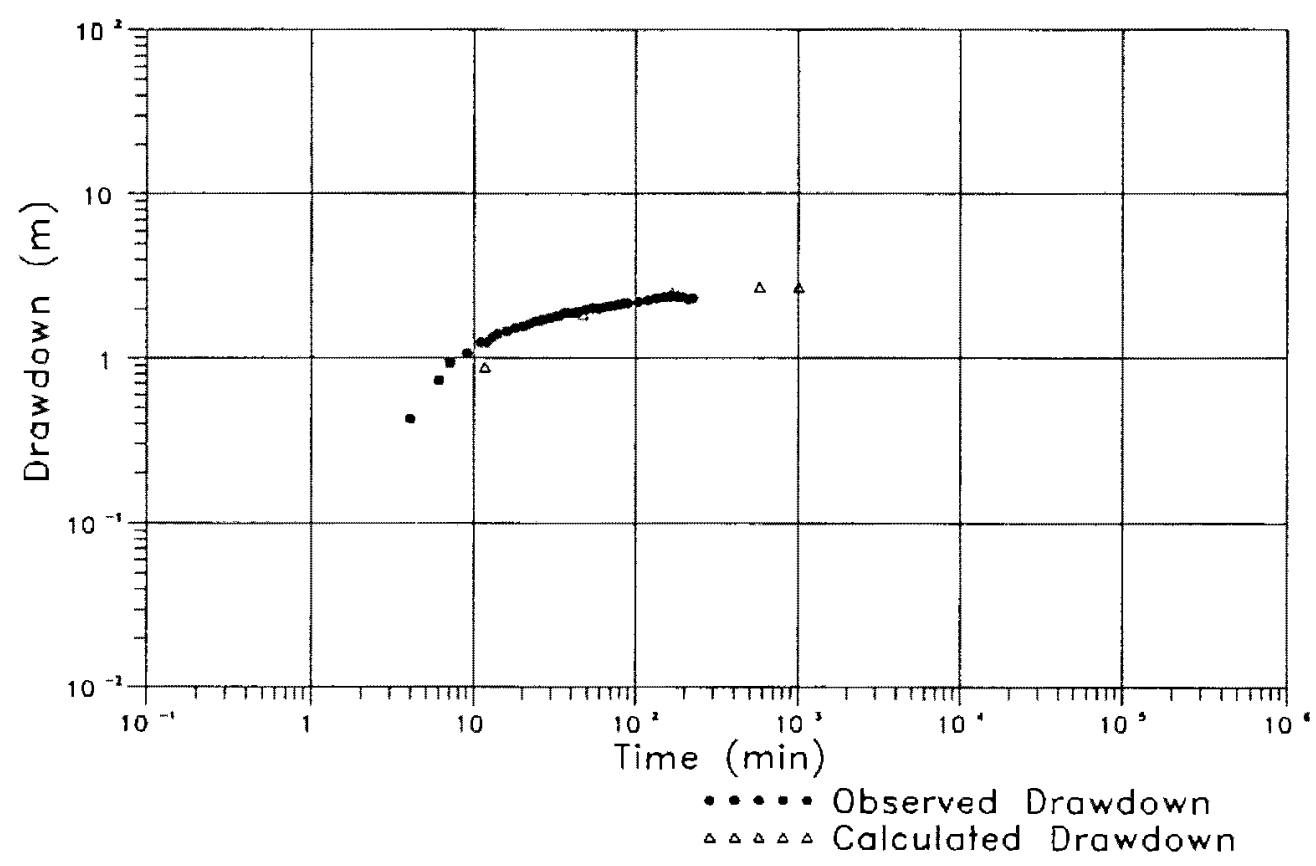

Calculated Data is from Model Run HST205

Figure 35. Results of simulation of pumping test H-4: piezometer 1611. 


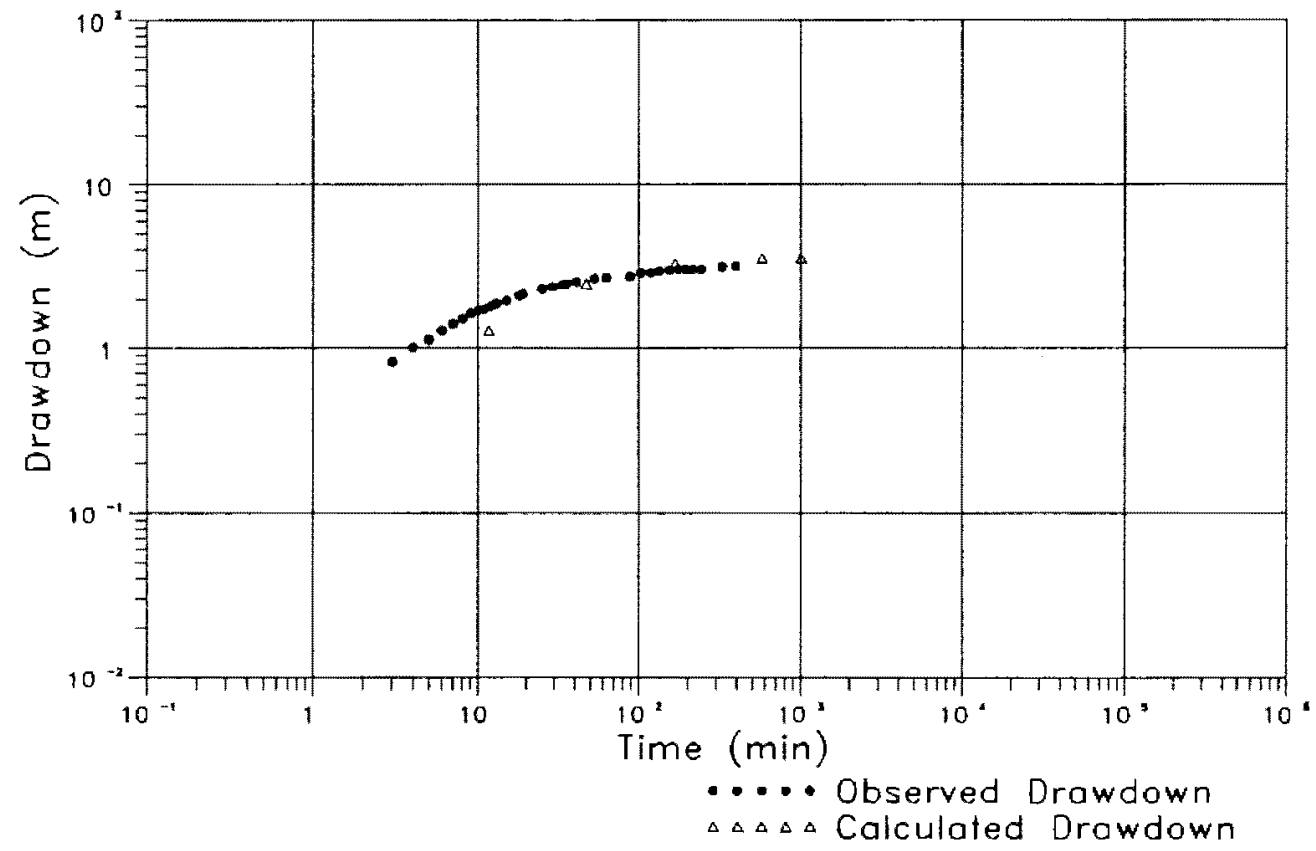

Calculated Data is from Model Run HST205

Figure 36. Results of simulation of pumping test H-4: piezometer 1615. 


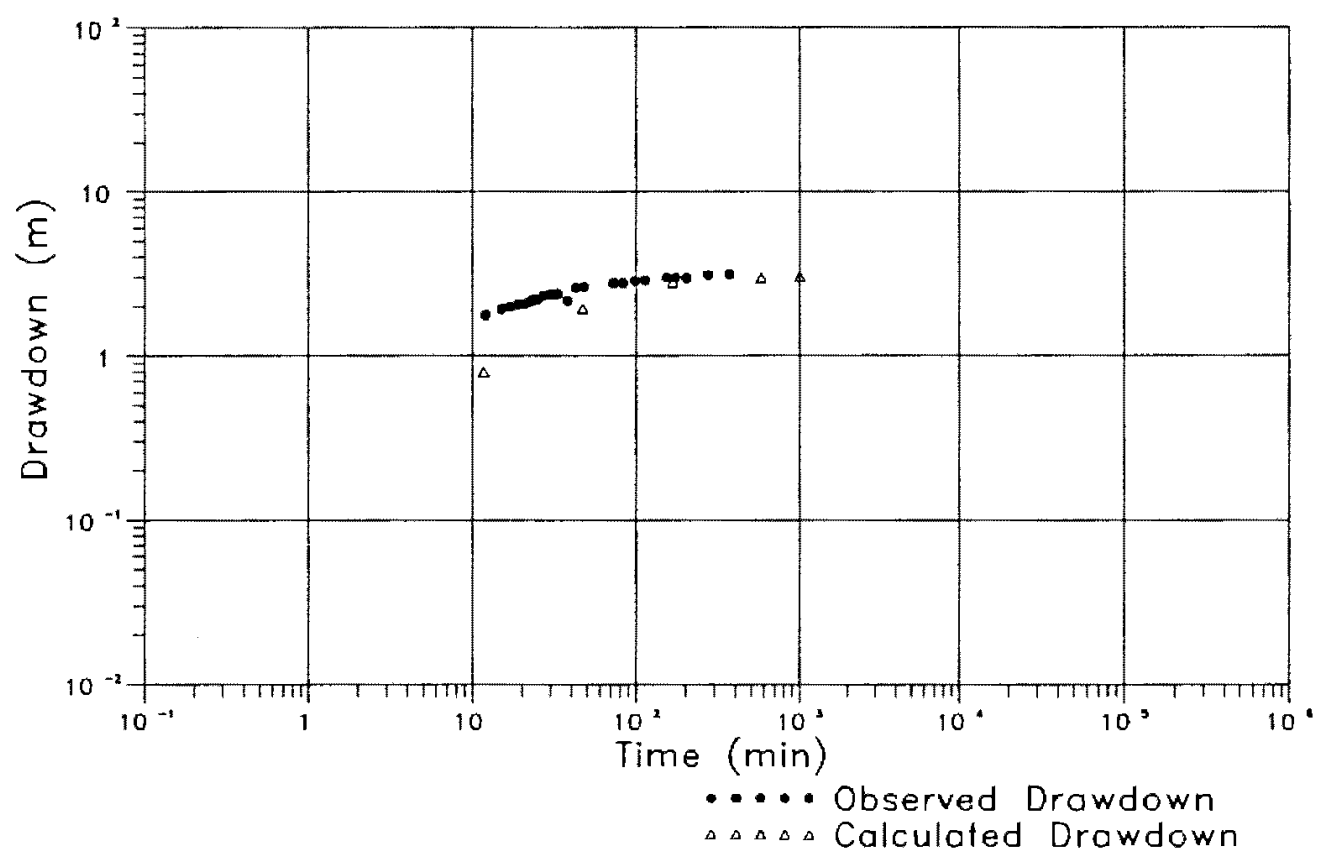

Calculated Data is from Model Run HST205

Figure 37. Results of simulation of pumping test $\mathrm{H}-4$ : piezometer 1624 


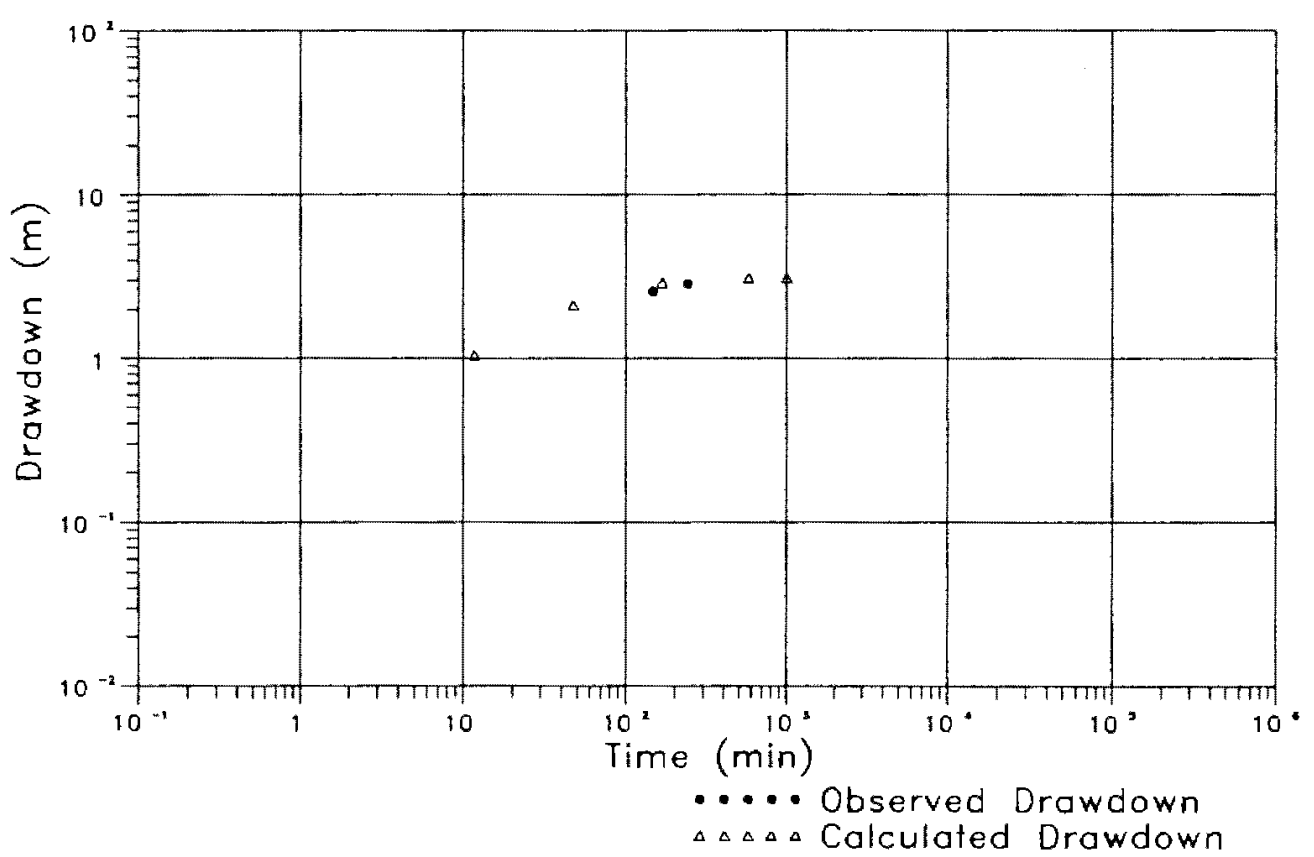

Calculated Data is from Model Run HST205

Figure 38. Results of simulation of pumping test $\mathrm{H}-4$ : observation well WW-1794. 


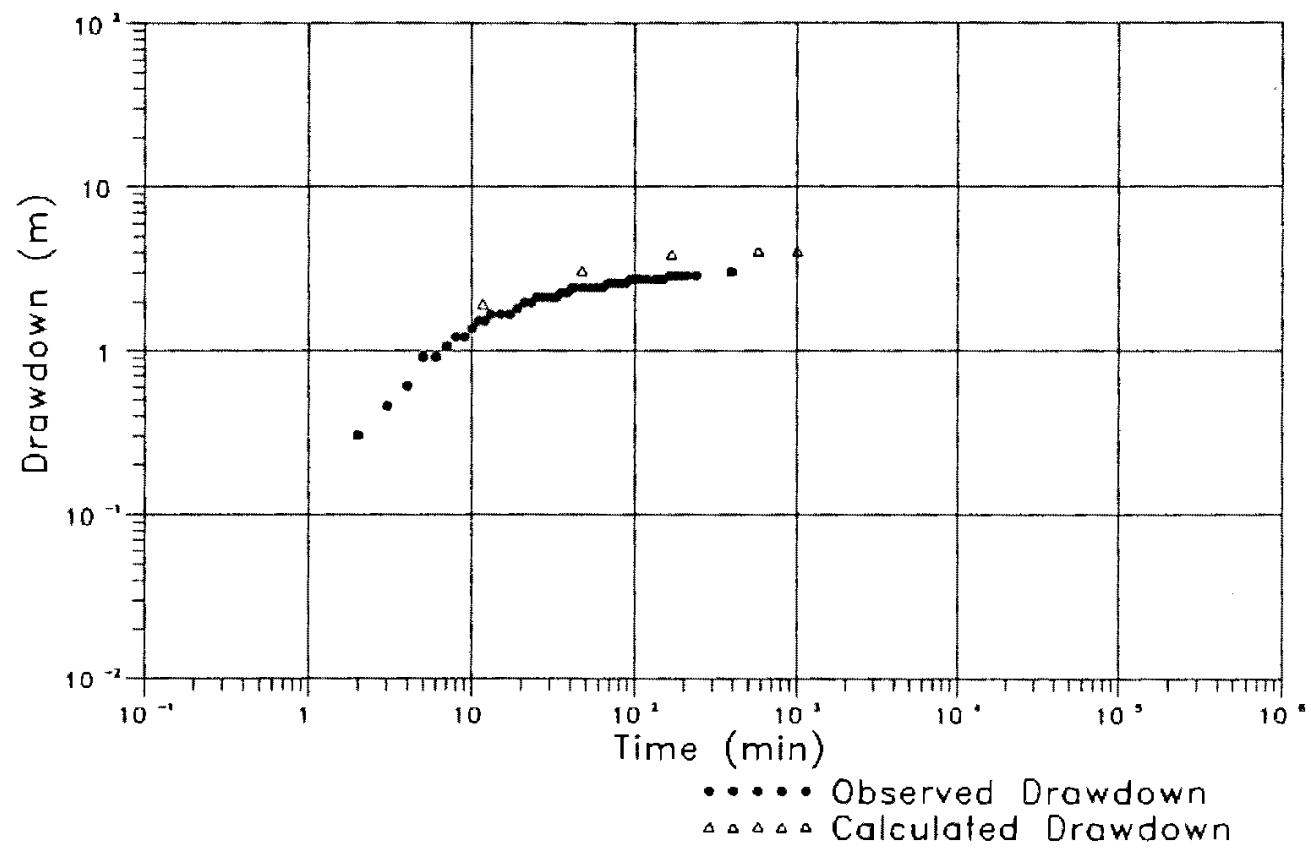

Calculated Data is from Model Run HST205

Figure 39. Results of simulation of pumping test $\mathrm{H}-4$ : observation well $\mathrm{H}-5$. 


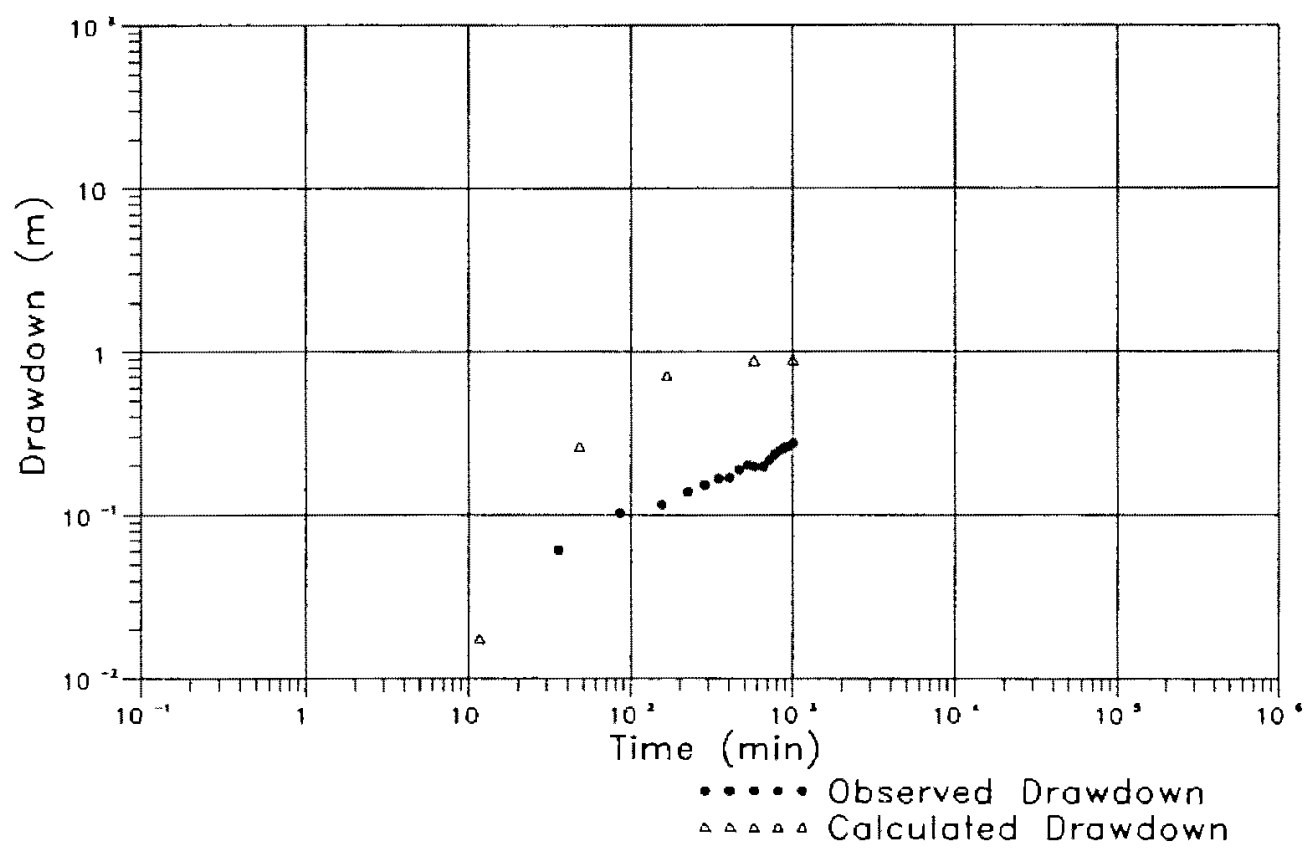

Calculated Data is from Model Run HST205

Note:

Piezometer HI-1 was not monitored during the pump test in hatchery well $\mathrm{H}-4$. The data presented here as Observed Drawdown is data from the recovery of the water level in piezometer $\mathrm{HI}-1$ after hatchery well $\mathrm{H}-3$ was shut off from pumping at $0.22 \mathrm{~m}^{3} / \mathrm{s}$. Pumping rate during the pump test in well $\mathrm{H}-4$ was $0.285 \mathrm{~m}^{3} / \mathrm{s}$. Therefore the actual response of $\mathrm{HI}-1$ to the pump test is expected to be higher.

Figure 40 . Results of simulation of pumping test $\mathrm{H}-4$ : piezometer $\mathrm{HI}-1$ 


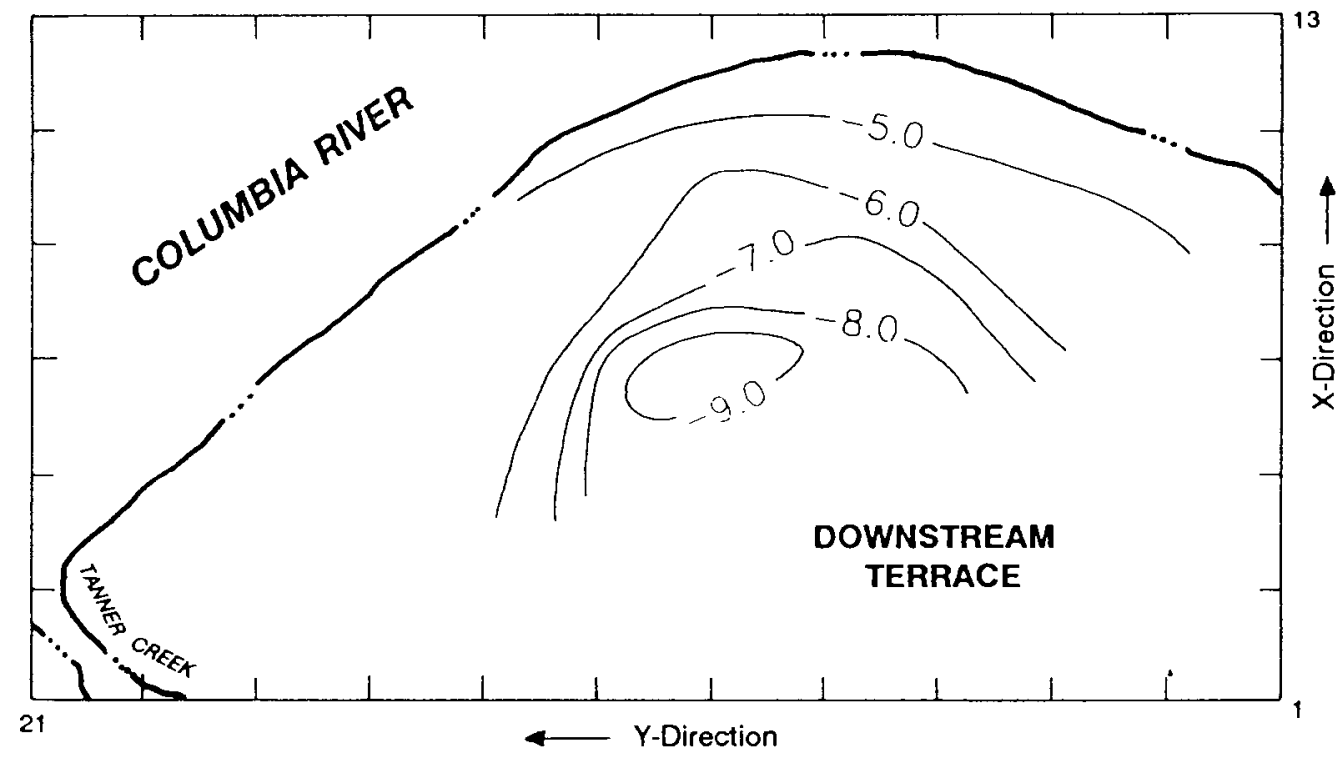

Measured Water Level

in the PSA Aquifer,

September 12, 1989, 14:00hrs.

Contours are Elevations

in meters.
Measured Water Level

in Deep Piezometers

$\begin{array}{ll}1610 & -5.2 \mathrm{~m} \\ 1611 & -5.6 \mathrm{~m} \\ 1614 & -8.1 \mathrm{~m} \\ 1615 & -9.0 \mathrm{~m} \\ 1632 & -5.5 \mathrm{~m} \\ 1741 & -5.0 \mathrm{~m} \\ 1946 & -7.5 \mathrm{~m} \\ 1949 & -7.1 \mathrm{~m} \\ 1953 & -5.2 \mathrm{~m} \\ 1958 & -5.9 \mathrm{~m}\end{array}$

Columbia River Stage: $+3 \mathrm{~m}$

Figure 41. Measured water levels in the PSA aquifer on September 12, 1989. 


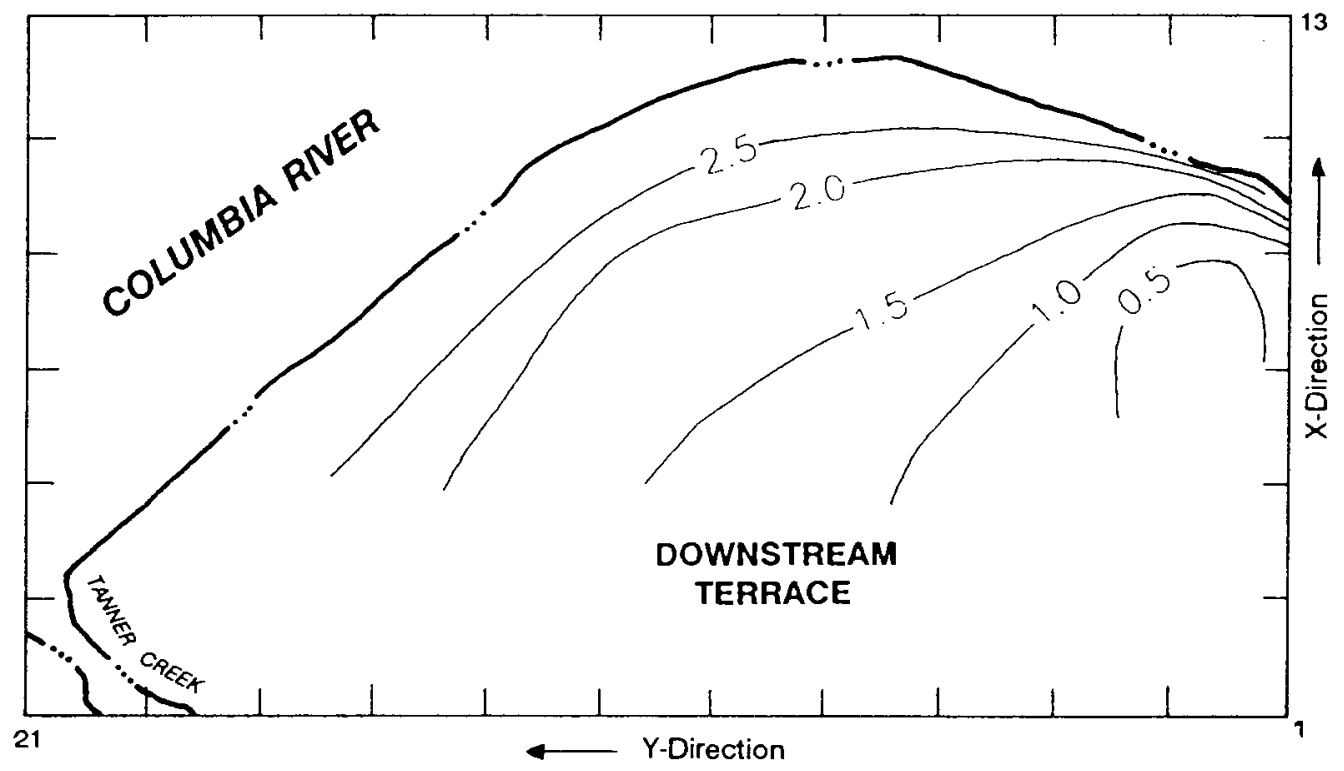

Measured Water Level in the Shallow Aquifer

(River Deposits/Fill),

September 12, 1989, 14:00hrs.

Contours are Elevations in meters.
Measured Water Level in Shallow Piezometers

1624

1626

1946

1949

1953

1958
$1.3 \mathrm{~m}$

$1.1 \mathrm{~m}$

$1.8 \mathrm{~m}$

$1.7 \mathrm{~m}$

$1.6 \mathrm{~m}$

$1.8 \mathrm{~m}$

Columbia River Stage: $3 \mathrm{~m}$

Figure 42. Measured water levels in the shallow unconfined aquifer on September 12, 1989. 


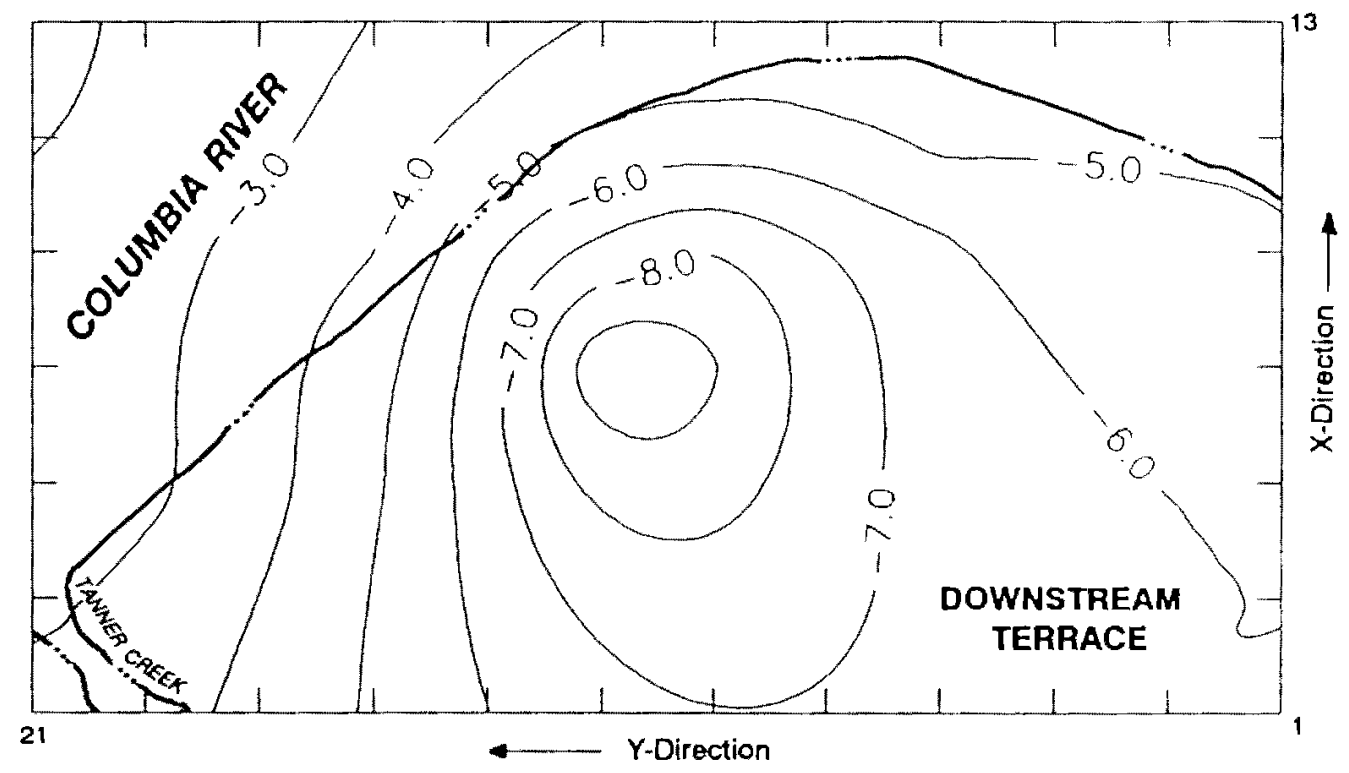

Galculated Water Level in the PSA Aquifer Model Run HST195

Contours are Elevations in meters.

Figure 43. Simulation of conditions on September 12, 1989: calculated water levels in the PSA aquifer. 


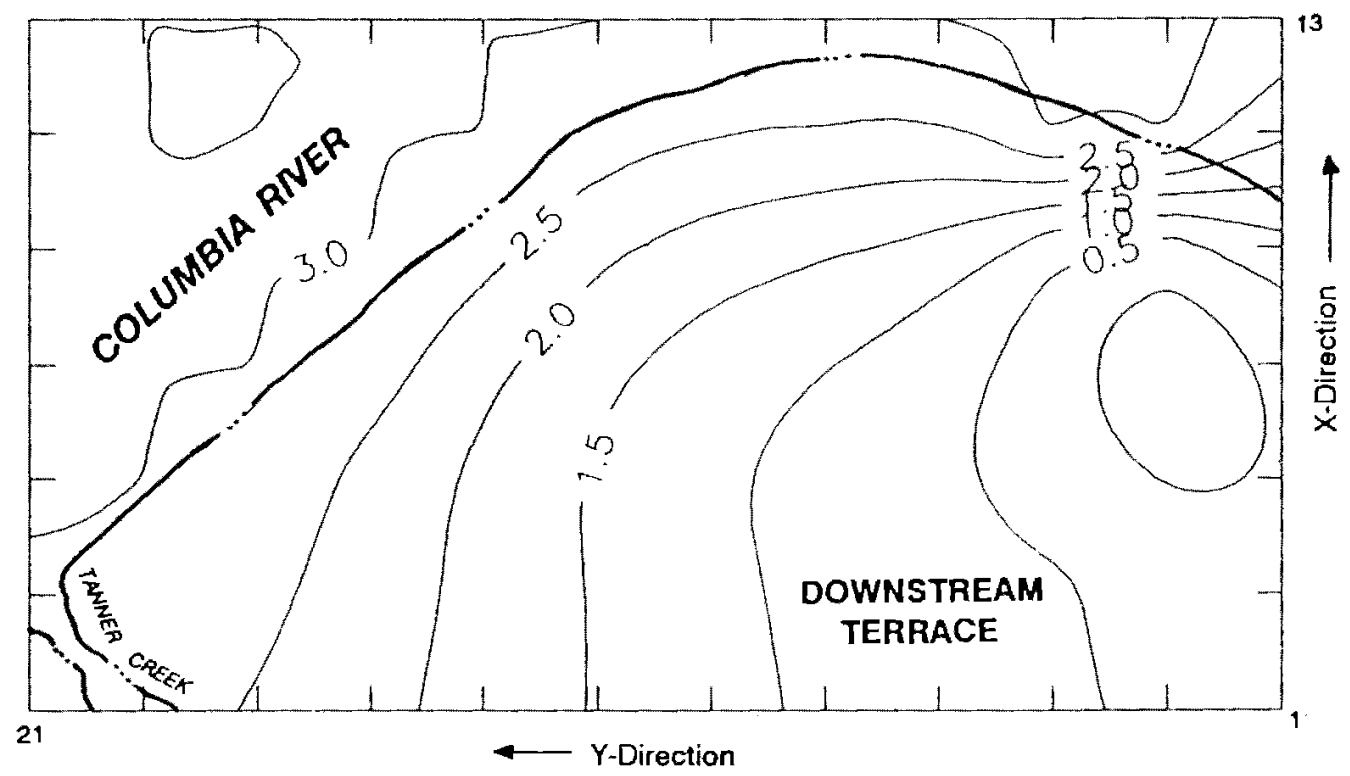

Calculated Water Level in the Shallow Aquifer Model Run HST195

Contours are Elevations in meters.

Figure 44. Simulation of conditions on September 12, 1989: calculated water levels in the shallow uncontined aquifer. 


\section{CHAPTER VI}

\section{CONCLUSIONS AND RECOMMENDATIONS}

\section{SUMMARY}

Based on the analysis of pumping tests, laboratory tests, subsurface exploration, and observation of water level changes as a result of changes in pumping rates, a conceptual model of the ground water system at Bonneville Dam was developed. It was found that recharge to the PSA aquifer, the main aquifer at the site, appears to be primarily derived from leakage through the confining layers mica sand and b-unit over a large area. The confining layers, in turn, receive recharge from the Columbia River and the overlying unconfined aquifer which is in direct hydraulic connection to the Columbia River. It appears that the PSA aquifer is separated from the Columbia River by a continuous aquitard layer or by fine-grained sediments sealing the river bottom.

Based on results from prior analysis and on the conceptual model, a ground water model was developed. The model was calibrated to water levels observed during a pumping test in hatchery well $\mathrm{H}-4$. The initial calibration of the model was then verified with a second set of conditions including pumping from deep hatchery wells and shallow dewatering wells. Water levels in both, the PSA aquifer and the shallow unconfined aquifer were matched by the model. Very little modification of the properties for the hydrogeologic units determined from prior analysis was necessary 
to achieve a close agreement between calculated and observed water levels for both sets of conditions (Table $\mathrm{VI}$ and $\mathrm{X}$ ).

\section{APPLICATIONS OF THE MODEL}

In the ongoing project, the model has been calibrated against observed ground water temperatures (L.R. Squier Associates, Inc., 1990). Currently, simulations of annual pumping and temperature cycles are being run to evaluate the effect of the proposed approach channel and of the relocation of the well field on the water supply for the hatchery. In addition, the model has been used to simulate potential contaminant transport from the Hamilton Island hazardous waste site on the Washington shore of the Columbia River towards the fish hatchery well field (Baron, 1989).

As more information becomes available from new hatchery wells, it will be possible to refine the model in the area of the new well field. Due to the lack of data, hydrogeologic properties in that area have been extrapolated from the central part of the downstream terrace area. It might be necessary to adjust the properties of the materials representing the PSA aquifer and the mica sand in the model in that area.

\section{CONCLUSIONS}

A close agreement of observed water levels and those calculated by the computer model was achieved for both tested pumping scenarios. This increases the confidence in pumping test analysis results as well as in the conceptual model and the assumptions on which the computer model is based. It appears that a continuous aquitard layer separating Columbia River and PSA aquifer is a valid 
representation of the river-aquifer system. Recharge to the aquifer is provided by vertical leakage through the confining layers over a large area. The confining layers mica sand and b-unit, receive recharge from the Columbia River and from the overlying unconfined aquifer which is in direct connection to the river. 


\section{REFERENCES}

Baron, D. ,1989, Contaminant transport from Hamilton Island: Draft Report to the U.S. Army Corps of Engineers, Portland District, $13 \mathrm{p}$.

BCA Geophysics, Inc., 1988, Bonneville navigation lock, instrumentation monitoring, weekly reports: Reports to the U.S. Army Corps of Engineers, Portland District.

Bear, J., 1979, Hydraulics of groundwater: McGraw-Hill, Inc., New York, 569 p.

Cooper, H. H., Jr., and Jacob, C. E., 1946, A generalized graphical method for evaluating formation constant and summarizing well field history: Transactions, American Geophysical Union, v. 27, p. 526-534.

Cornforth Consultants, Inc., 1986a, Pump Test Data, Bonneville navigation lock site, Columbia River, Oregon, 2 volumes: Report to the U.S. Army Corps of Engineers, Portland District, $18 \mathrm{p}$.

Cornforth Consultants, Inc., 1986b, Conceptual dewatering considerations, Bonneville navigation lock site, Columbia River, Oregon: Memorandum to the U.S. Army Corps of Engineers, Portland District, 8 p.

Cornforth Consultants, Inc., 1987, Fish hatchery water supply, Bonneville navigation lock site, Columbia River, Oregon: Report to the U.S. Army Corps of Engineers, Portland District, $39 \mathrm{p}$.

Fetter, C.W., 1988, Applied hydrogeology (2nd edition): Charles E. Merril Publishing Company, Columbus, Ohio, $592 \mathrm{p}$.

Freeze, R.A., and Cherry, J.C., 1979, Groundwater: Prentice Hall, Englewood Cliffs, New Jersey, 604 p.

Hantush, M.S., and C.E. Jacob, 1955, Non-steady radial flow in an infinite leaky aquifer: Transactions, American Geophysical Union, v. 36, p. 95-100.

Heath, R.C., and F.W. Trainer, 1968, Introduction to ground-water hydrology: John Wiley and Sons, Inc., New York, 284 p.

Holdredge, C.P., 1937, Final geological report on the Bonneville project: U.S. Army Corps of Engineers, Portland District, $36 \mathrm{p}$. 
Johnson, A.G., 1973, Pore pressure changes associated with creep events on the San Andreas Fault [PhD dissertation]: Stanford, California, Stanford University, $177 \mathrm{p}$.

Johnson, A.G., 1988, FORTRAN program WLPROCS2: unpublished, Department of Geology, Portland State University, Portland, Oregon.

Kipp, K. L., 1987, HST3D: A computer code for simulation of heat and solute transport in three-dimensional groundwater flow systems: U.S. Geological Survey Water-Resources Investigations Report 86-4095, 517 p.

L.R. Squier Associates, Inc., 1989, Bonneville navigation lock, instrumentation monitoring, monthly reports: Reports to the U.S. Army Corps of Engineers, Portland District.

L.R. Squier Associates, Inc., 1990, Bonneville ground water model simulating operations for the new fish hatchery well system: Report to the U.S. Army Corps of Engineers, Portland District, $57 \mathrm{p}$.

Neuman, S.P., and P.A. Witherspoon, 1969a, Theory of flow in a two aquifer system: Water Resources Research, v. 5, p. 803-816.

Neuman, S.P., and P.A. Witherspoon, 1969b, Applicability of current theories of flow in leaky aquifers: Water Resources Research, v. 5, p. 817-829.

Neuman, S.P. and P.A. Witherspoon, 1972, Field determination of the hydraulic properties of leaky multiple aquifer systems: Water Resources Research, v. 8 , p. 1284-1298.

Rittenhouse-Zeman \& Associates, 1988, Subsurface material unit identification and correlation, Bonneville navigation lock: Report to the U.S. Army Corps of Engineers, Portland District, $14 \mathrm{p}$.

Robinson \& Noble, Inc., 1988, Bonneville Fish Hatchery Emergency Supply Well WW 2033: Report to the U.S. Army Corps of Engineers, Portland District, 6 p.

Theis, C. V., 1935, The relation between the lowering of the piezometric surface and the rate and duration of discharge of a well using ground water storage: Transactions, American Geophysical Union, p. 518-524.

U.S. Army Corps of Engineers, Portland District, 1984, Geology, excavation and foundation: Design Memorandum No. 3, Bonneville Navigation Lock, Columbia River, Oregon/Washington, 2 parts, $118 \mathrm{p}$.

U.S. Army Corps of Engineers, Portland District, 1988a, Geology, excavation and foundation: Design Memorandum No. 3, Supplement No. 1, Bonneville Navigation Lock, Columbia River, Oregon/Washington, 204 p. 
U.S. Army Corps of Engineers, Portland District, 1988b, Fish hatchery well relocation: Design Memorandum No. 9, Bonneville Navigation Lock, Columbia River, Oregon/ Washington, $98 \mathrm{p}$.

U.S. Army Corps of Engineers, Portland District, 1989, Geology, excavation and foundation: Design Memorandum No. 3, Supplement No. 2, Bonneville Navigation Lock, Columbia River, Oregon/Washington, 126 p.

U.S. Army Corps of Engineers, Portland District, 1990, Fish hatchery well relocation: Feature Design Memorandum No. 9, Supplement No. 1, Bonneville Navigation Lock, Columbia River, Oregon/Washington, $116 \mathrm{p}$.

van der Heijde, P.K.M., 1985, TSSLEAK: International Ground Water Modeling Center, Holcomb Research Institute, Butler University, Indianapolis, Indiana, 28 p. 
APPENDIX A

PIEZOMETER AND WELL INFORMATION 
MONITORING WELL AND PIEZOMETER DATA

\begin{tabular}{|c|c|c|c|c|}
\hline $\begin{array}{c}\text { Piezometer, } \\
\text { Monitoring Well No. }\end{array}$ & $\begin{array}{l}\text { Top of PVC } \\
\text { Elevation (1) }\end{array}$ & $\begin{array}{l}\text { Monitored Zone } \\
\text { Elevation (1) }\end{array}$ & $\begin{array}{l}\text { Geologic Units } \\
\text { monitored }\end{array}$ & $\begin{array}{l}\text { Pump Tests } \\
\text { monitored }\end{array}$ \\
\hline $\begin{array}{c}\text { H-5 (MW-3) } \\
1610-\mathrm{Z1} \\
1611-\mathrm{Z1} \\
1611-\mathrm{Z2} \\
1612-\mathrm{Z1}\end{array}$ & $\begin{array}{l}17.9 \\
15.2 \\
15.9 \\
15.9 \\
16.0\end{array}$ & $\begin{array}{c}-27.7 /-38.1 \\
-9.3 /-57.2 \\
-49.0 /-58.6 \\
0 /-14.6 \\
0.2 /-47.5\end{array}$ & $\begin{array}{c}\text { PSA } \\
\text { PSA, MS } \\
\text { PSA } \\
\text { BU } \\
\text { BU, MS, PSA }\end{array}$ & $\begin{array}{c}H-4 \\
H-H, H \\
H-3, H-4 \\
H-3, H-4 \\
H-3, H-4\end{array}$ \\
\hline $\begin{array}{c}1615-Z \\
1624-Z 1 \\
1624-Z 2 \\
1629-Z 1 \\
1629-Z 2\end{array}$ & $\begin{array}{l}18.4 \\
18.4 \\
18.4 \\
17.2 \\
17.2\end{array}$ & $\begin{array}{c}4.0 /-50.1 \\
-8.8 /-52.9 \\
4.9 /-3.1 \\
-36.2 /-59.0 \\
0 /-22.9\end{array}$ & $\begin{array}{c}\text { BU, MS, PSA } \\
\text { BU, MS, PSA } \\
\text { BU, MS } \\
\text { PSA } \\
\text { BU, MS, PSA }\end{array}$ & $\begin{array}{c}H-4 \\
H-4 \\
H-4 \\
H-4, A-1, A-2 \\
H-4, A-1, A-2\end{array}$ \\
\hline $\begin{array}{l}1632-\mathrm{Z} 1 \\
1632-\mathrm{Z} 1 \\
1700-\mathrm{Z1} \\
1700-\mathrm{Z2} \\
1728-\mathrm{Z} 1\end{array}$ & $\begin{array}{l}15.5 \\
15.5 \\
24.5 \\
24.5 \\
24.2\end{array}$ & $\begin{array}{c}-43.7 /-58.4 \\
-3.7 /-40.2 \\
-27.4 /-38.2 \\
0 /-25.6 \\
-4.3 /-23.2\end{array}$ & $\begin{array}{c}\text { PSA, TCA } \\
\text { PSA, TCA } \\
\text { BRI } \\
\text { MS } \\
\text { BU, MS }\end{array}$ & $\begin{array}{c}H-4 \\
H-4 \\
H-3 \\
H-3 \\
A-1, A-2\end{array}$ \\
\hline $\begin{array}{l}1728-Z 2 \\
1730-Z 1 \\
1730-Z 2 \\
1730-Z 3 \\
1732-Z 1\end{array}$ & $\begin{array}{l}24.2 \\
23.0 \\
23.0 \\
23.0 \\
19.6\end{array}$ & $\begin{array}{c}3.4 /-2.7 \\
31.8 /-34.4 \\
3.7 /-30.5 \\
21.3 / 4.8 \\
-7.3 /-18.3\end{array}$ & $\begin{array}{c}\text { BU } \\
\text { PSA } \\
\text { BU, MS, PSA } \\
\text { F/RD, BU } \\
\text { BU, MS }\end{array}$ & $\begin{array}{c}A-1, A-2 \\
H-3 \\
H-3 \\
H-3 \\
A-1, A-2\end{array}$ \\
\hline $\begin{array}{l}1732-Z 2 \\
1733-Z 1 \\
1733-Z 2 \\
1738-Z 1 \\
1738-Z 2\end{array}$ & $\begin{array}{l}19.7 \\
23.2 \\
23.2 \\
18.4 \\
18.4\end{array}$ & $\begin{array}{c}4.9 /-3.7 \\
0.3 /-18.3 \\
20.7 / 1.5 \\
-14.3 /-40.8 \\
4.6 /-11.0\end{array}$ & $\begin{array}{c}\text { BU } \\
\text { BU, MS } \\
\text { F/RD } \\
\text { MS, PSA } \\
\text { F/RD, BU, MS }\end{array}$ & $\begin{array}{l}A-1, A-2 \\
A-1, A-2 \\
A-1, A-2 \\
A-1, A-2 \\
A-1, A-2\end{array}$ \\
\hline $\begin{array}{l}1741-Z 1 \\
1741-Z 2 \\
1743-Z 1 \\
1743-Z 2 \\
1745-Z 1\end{array}$ & $\begin{array}{l}18.5 \\
18.5 \\
18.5 \\
18.5 \\
18.8\end{array}$ & $\begin{array}{l}-5.8 /-38.4 \\
22.6 /-5.5 \\
-7.9 /-30.2 \\
16.2 / 6.1 \\
-5.8 /-35.4\end{array}$ & $\begin{array}{c}\text { MS, PSA } \\
\text { F/RD, BU } \\
\text { BU, MS, PSA } \\
\text { F/RD, BU } \\
\text { BU, MS, PSA }\end{array}$ & $\begin{array}{c}A-1, A-2 \\
A-1, A-2 A-1, A-2 \\
A-1, A-2 \\
A-1, A-2 \\
A-1, A-2\end{array}$ \\
\hline $\begin{array}{l}1745-Z 2 \\
1746-Z 1 \\
1746-Z 2 \\
1747-Z 1 \\
1747-Z 2\end{array}$ & $\begin{array}{l}18.8 \\
19.7 \\
19.7 \\
19.0 \\
19.0\end{array}$ & $\begin{array}{c}2.1 / 1.5 \\
-6.1 /-39.6 \\
16.5 /-1.5 \\
-7.3 / 40.2 \\
4.3 /-4.0\end{array}$ & $\begin{array}{c}\text { BU } \\
\text { BU, MS, PSA } \\
\text { F/RD, BU, MS } \\
\text { BU, MS, PSA } \\
\text { F/RD, BU }\end{array}$ & $\begin{array}{l}A-1, A-2 \\
A-1, A-2 \\
A-1, A-2 \\
A-1, A-2 \\
A-1, A-2\end{array}$ \\
\hline $\begin{array}{c}1749-Z 1 \\
1749-Z 2 \\
1755-Z 1 \\
1755-Z 2 \\
1794-Z\end{array}$ & $\begin{array}{l}19.7 \\
19.7 \\
18.3 \\
18.2 \\
15.2\end{array}$ & $\begin{array}{c}-7.3 /-38.4 \\
17.4 /-2.7 \\
-12.5 /-30.5 \\
4.3 /-10.4 \\
-34.4 /-40.1\end{array}$ & $\begin{array}{c}\text { BU, MS, PSA } \\
\text { F/RD } \\
\text { MS } \\
\text { BU, MS } \\
\text { PSA }\end{array}$ & $\begin{array}{c}A-1, A-2 \\
A-1, A-2 \\
A-1, A-2 \\
A-1, A-2 \\
H-4\end{array}$ \\
\hline
\end{tabular}




\section{PUMPING WELL INFORMATION}

\section{WW-1794}

Surface Elevation $15.9 \mathrm{~m}, 65.5 \mathrm{~m}$ deep,

6 inch screen, \#20-, 40-, 80-, 100-slot from depth 51.8 to $57.9 \mathrm{~m}$ (Elevation 35.9 to $42.0 \mathrm{~m}$ )

Pump intake at depth 42.7 , elevation $-26.8 \mathrm{~m}$

\section{WW-1800}

Surface Elevation $10.9 \mathrm{~m}, 67.1 \mathrm{~m}$ deep

8 inch screen, \#40-, 80-, 100-slot from depth $50.3 \mathrm{~m}$ to $57.9 \mathrm{~m}$ (Elevation -39.4 to $-47.1 \mathrm{~m}$ )

Pump intake at depth $42.7 \mathrm{~m}$, elevation $-31.8 \mathrm{~m}$

\section{A-1 (WW-1816)}

Surface Elevation $20.1 \mathrm{~m}, 30.5 \mathrm{~m}$ deep

14 inch telescopic iron screen, \#10 slot from 25.0 to $30.5 \mathrm{~m}$ depth (Elevation -4.9 to $-10.4 \mathrm{~m}$ )

Pump intake at depth $24.4 \mathrm{~m}$, elevation $-5.1 \mathrm{~m}$

\section{A-2 (nW-1805)}

Surface Elevation $20.7 \mathrm{~m}, 61.0 \mathrm{~m}$ deep,

14 inch telescopic screen, \# 100 slot from 50.0 to $52.4 \mathrm{~m}$ depth (Elevation -29.3 to $31.7 \mathrm{~m}$ ), \#10 slot from 53.7 to $59.7 \mathrm{~m}$ depth (Elevation -32.0 to $-39.1 \mathrm{~m}$ )

Pump intake at depth 49.4 , elevation $-30.0 \mathrm{~m}$

\section{$\mathrm{H}-3$}

Surface Elevation $16.2 \mathrm{~m}, 56.4 \mathrm{~m}$ deep

15 inch diameter telescopic stainless steel screen, \#100 slot from 45.4 to $54.6 \mathrm{~m}$ depth (Elevation -29.0 to $-38.1 \mathrm{~m}$ ), riser pipe from 43.9 to $45.4 \mathrm{~m}$ depth (Elevation -27.5 to $-38.8 \mathrm{~m}$ ), tailpipe from 54.6 to $56.4 \mathrm{~m}$ depth (Elevation $-38.1 \mathrm{~m}$ to $-40.0 \mathrm{~m}$ ),

pump intake at depth $42.4 \mathrm{~m}$, elevation $-25.9 \mathrm{~m}$

\section{$\underline{H-4}$}

Surface Elevation $17.6 \mathrm{~m}, 57.9 \mathrm{~m}$ deep,

15 inch diameter telescopic stainless steel screen, \#100 slot from 48.8 to $56.4 \mathrm{~m}$ depth (Elevation -31.2 to $-38.8 \mathrm{~m}$ ), riser pipe from 47.2 to $48.8 \mathrm{~m}$ depth (Elevation -29.7 to $31.2 \mathrm{~m}$ ), tail pipe from 56.4 to $57.9 \mathrm{~m}$ depth (Elevation -38.8 to $40.4 \mathrm{~m}$ ),

pump intake at depth $47.3 \mathrm{~m}$, elevation $-29.8 \mathrm{~m}$

\section{WW-2030 (DW-3)}

Surface Elevation $18.7 \mathrm{~m}, 81.7 \mathrm{~m}$ deep

16 inch diameter screen, \#50 and \#30 slot sizes from depth 47.2 to $81.7 \mathrm{~m}$ (Elevation $-28.6 \mathrm{~m}$ to $-63.0 \mathrm{~m}$ ) no permanent pump installed

\section{F-1 (WW-2033)}

Surface Elevation $15.8 \mathrm{~m}, 68.3 \mathrm{~m}$ deep

16 inch diameter screen, \#150 slot size from depth 53.0 to $54.9 \mathrm{~m}$ (Elevation -37.2 to $-39.1 \mathrm{~m}$ ) and from depth 64.9 to $65.5 \mathrm{~m}$ (Elevation -49.1 to $-49.7 \mathrm{~m}$ ) pump intake at depth $50.3 \mathrm{~m}$, elevation $\mathbf{3 4 . 5 \mathrm { m }}$ 
APPENDIX B

CALCULATIONS FOR THE RATIO METHOD 


\section{CALCULATIONS FOR THE RATIO METHOD}

Reference: Neuman and Witherspoon (1972)

Initial Information

The method presented in the above paper was applied to data from pumping test A-2 and piezometer 1738 which was monitored during the pumping test.

Piezometer $1738-Z 1$ is screened in the PSA aquifer, piezometer $1738-\mathrm{Z2}$ is screened in the mica sand unit.

Distance between well A-2 and piezometer 1738, $r: \quad r=558 \mathrm{ft}$

Distance from the bottom of the zone monitored by piezometer $1738-Z 2$ to the top of the PSA aquifer, $z: z=18 \mathrm{ft}$

From prior pumping test analysis:

PSA aquifer storativity, S:

$S=2.5^{*} 10^{-3}$

PSA aquifer transmissivity, T:

$T=191,250 \mathrm{gpd} / \mathrm{ft}$

PSA aquifer conductivity, $K$ :

$K=1,400 \mathrm{gpd} / \mathrm{ft}^{2}$

From consolidation tests of soil samples from the borings for piezometers 1644 and 1652 (USACOE, 1984) located in the vicinity of piezometer 1738 the specific storage, $\mathrm{S}_{\mathbf{s}}$, of the mica sand unit was determined:

mica sand unit specific storage, $S_{s}^{\prime}$ :

$S_{s}^{\prime}=2.41 * 10^{-4} \mathrm{ft}^{-1}$ 
Calculations

The method relies on a family of type curves of the ratio of the drawdown in the aquitard to the drawdown in the aquifer, $s^{\prime} / s$, versus a dimensionless time parameter, $t_{D}$.

The first step is to calculate the value of $s^{\prime} / s$ for the piezometer as some time, $\mathrm{t}$ :

$$
\begin{aligned}
& \text { at } t=100 \mathrm{~min} \quad \mathrm{~s}^{\prime}=0.4 \mathrm{ft} \\
& s=1.8 \mathrm{ft} \\
& ==>s^{\prime} / s=0.22
\end{aligned}
$$

Then, $t_{0}$ is calculated from

$$
\begin{aligned}
t_{D} & =9.28 * 10^{-5} * T * t /\left(r^{2} * S\right) \\
& =9.28 * 10^{-5} * 191,250 * 100 /\left(558^{2} * 2.5^{*} 10^{-3}\right) \\
& =2.3
\end{aligned}
$$

From the type curves presented by Neuman and Witherspoon (1972) the dimensionless time parameter for the aquitard, $t_{0}{ }^{\prime}$, is determined:

$$
t_{0}{ }^{\prime}=0.6
$$

Then, the diffusivity of the aquitard, $a^{\prime}$, is calculated:

$$
\begin{aligned}
\alpha^{\prime} & =\left(z^{2} / t\right) * t_{D}{ }^{*}+1.077^{\star} 10^{4} \\
& =\left(18^{2} / 100\right) * 0.6 * 1.077^{\star} 10^{4} \\
& =20937 \mathrm{gpd} / \mathrm{ft}
\end{aligned}
$$

Finally, the conductivity of the aquitard, $\mathrm{K}^{\prime}$, is calculated:

$$
\begin{aligned}
K^{\prime} & =\alpha^{\prime} * \mathrm{~S}_{\mathrm{s}}^{\prime} \\
& =20937 \mathrm{gpd} / \mathrm{ft}^{*} 2.41 * 10^{-4} \mathrm{ft}^{-1} \\
& =5.05 \mathrm{gpd} / \mathrm{ft}^{2} \\
\mathrm{~K}^{\prime} & =2.4 * 10^{-6} \mathrm{~m} / \mathrm{s}
\end{aligned}
$$


APPENDIX C

GEOMETRY OF THE COMPUTER MODEL 


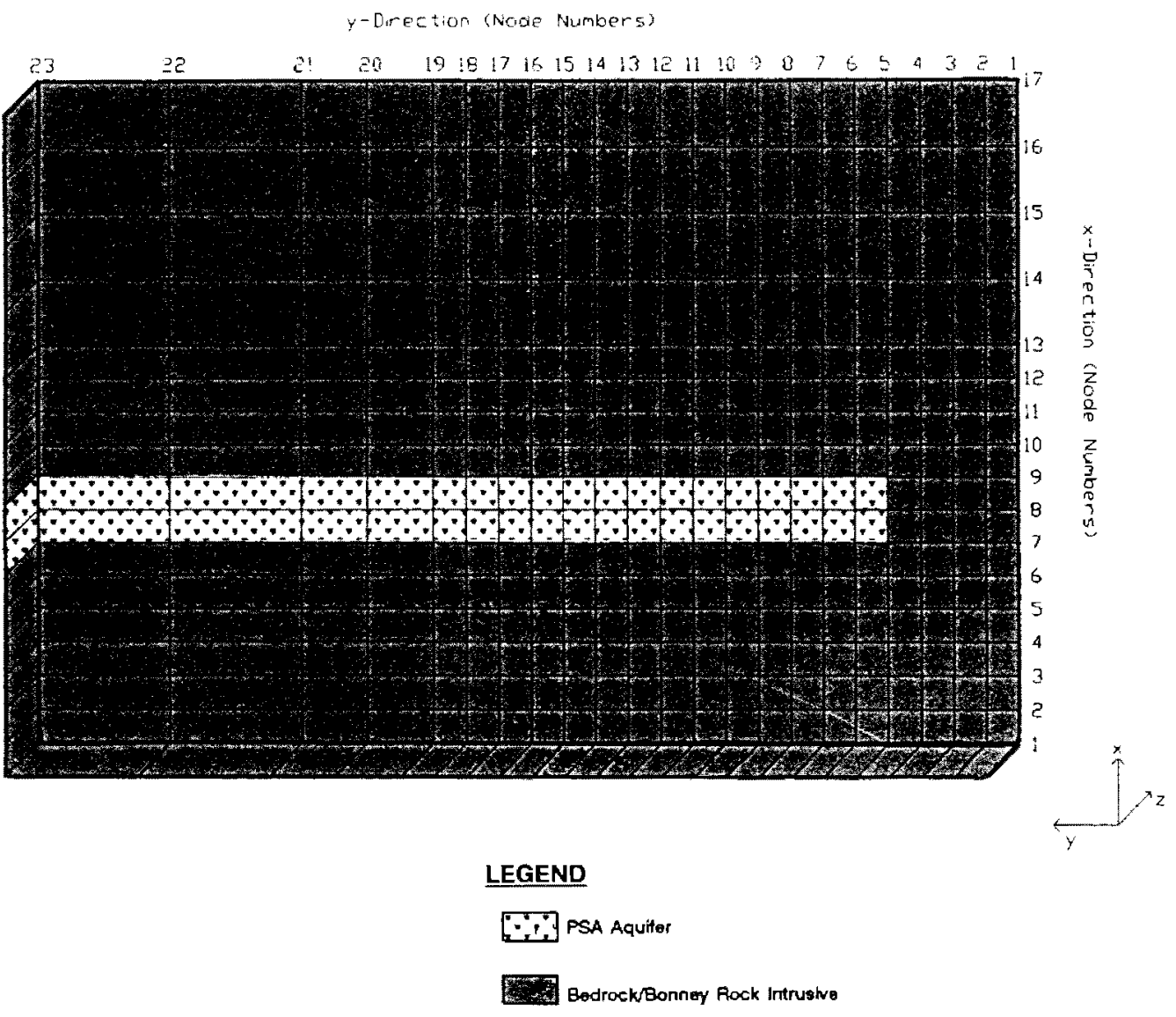

LAYER 1 (EL. $-52 m--64 m$ ) 
y-Direction (Node Numbers)

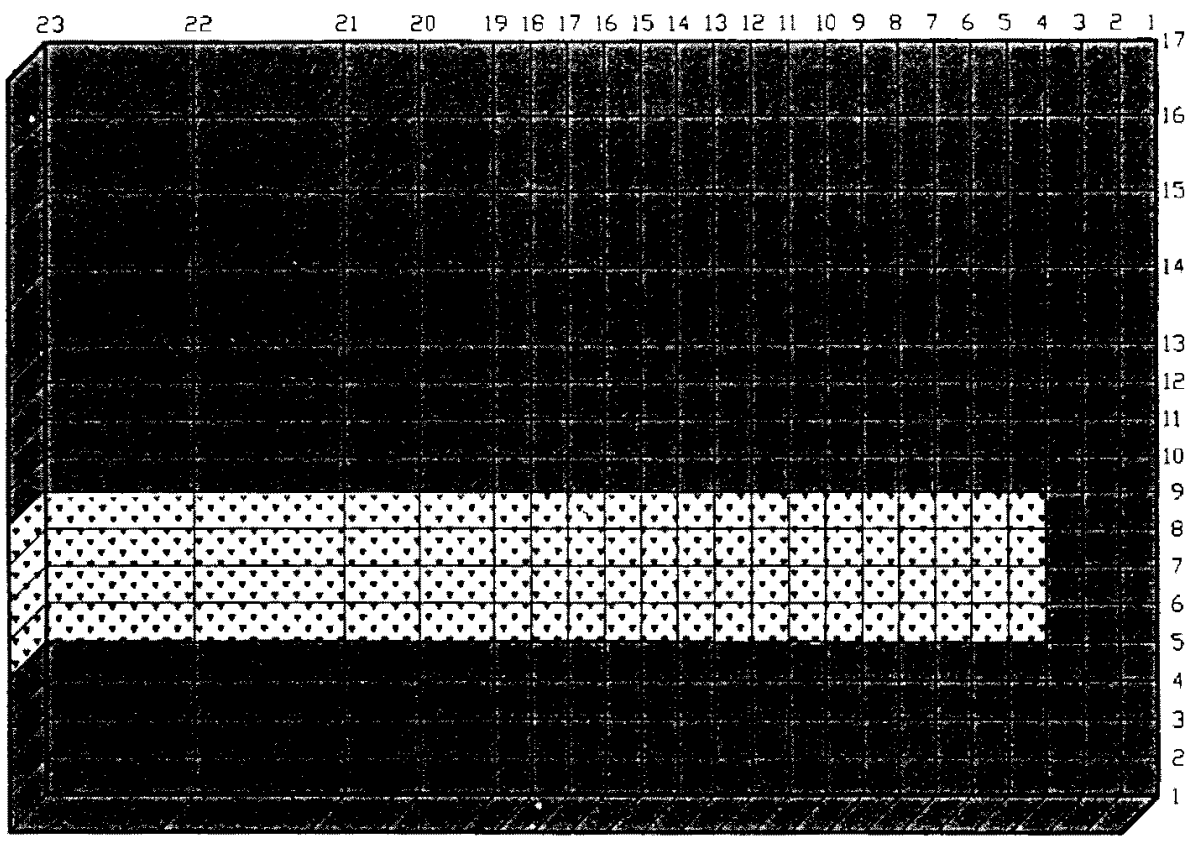

LEGEND

$\because \because$ PSA AquHER

3edrock/Bonney Fock Intrusive

LAYER 2 (EL. $-40 m--52 m$ ) 


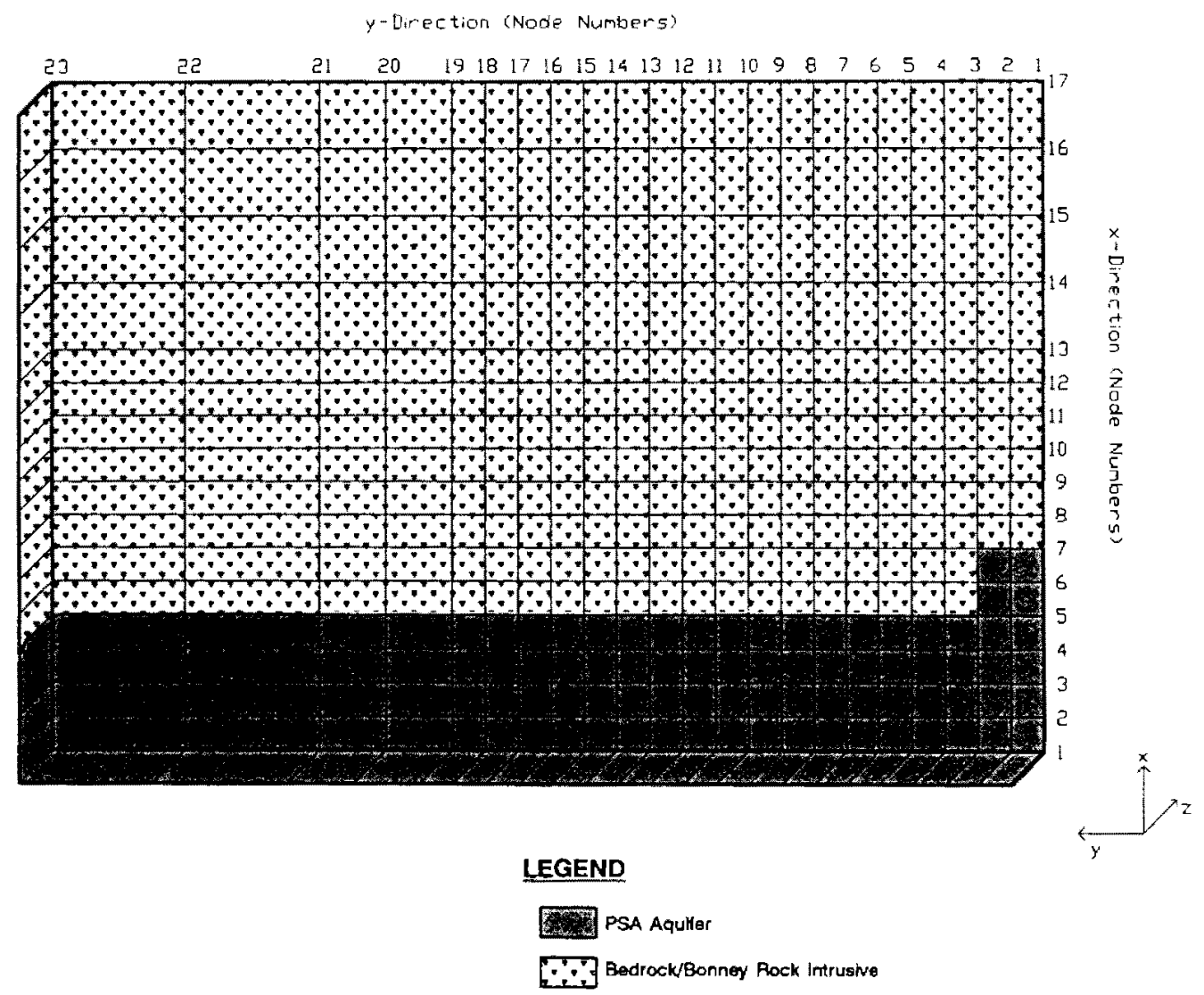

LAYER 3 (EL. $-28 m--40 m$ ) 


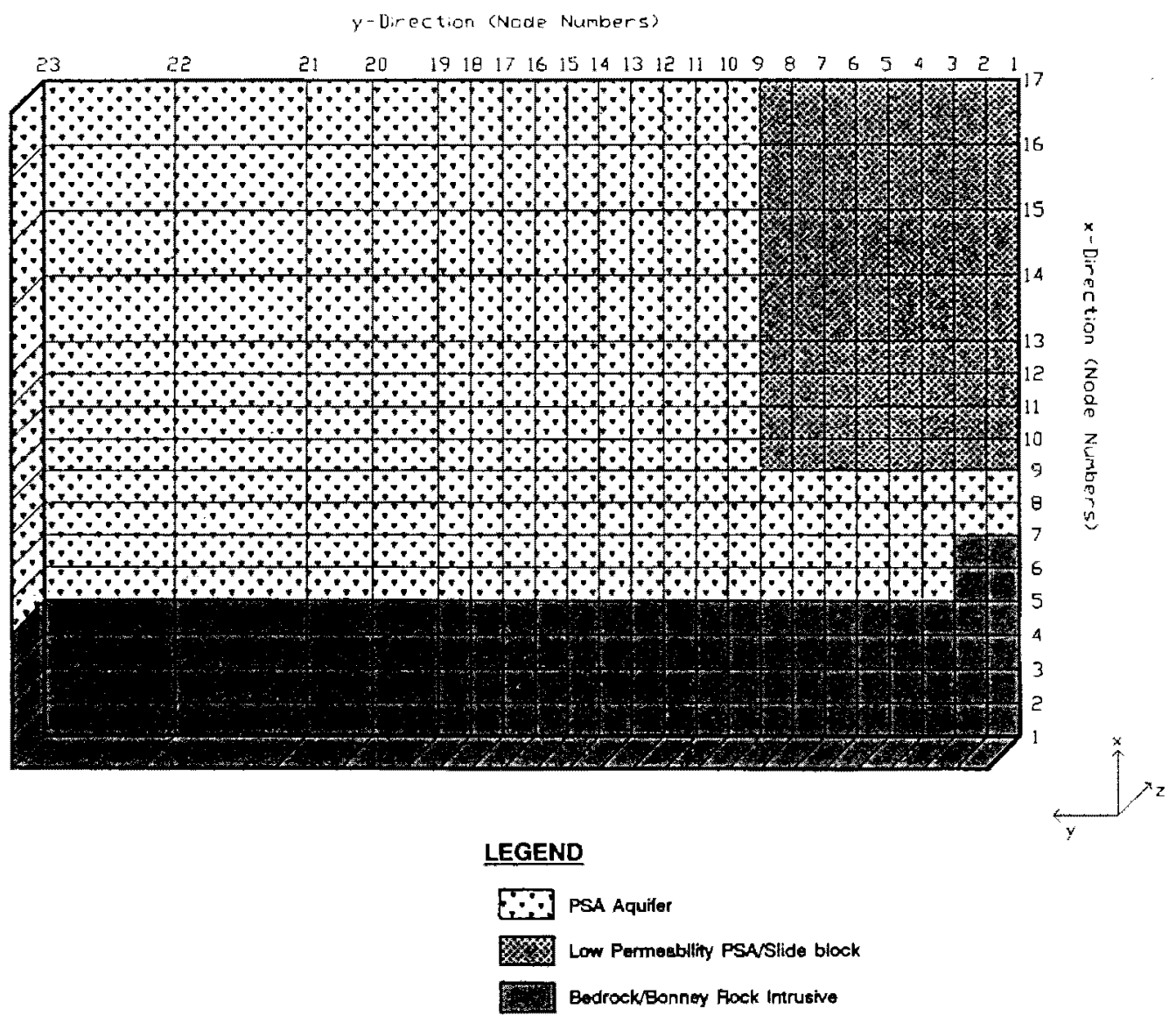

LAYER 4 (EL. $-20 m--28 m$ ) 


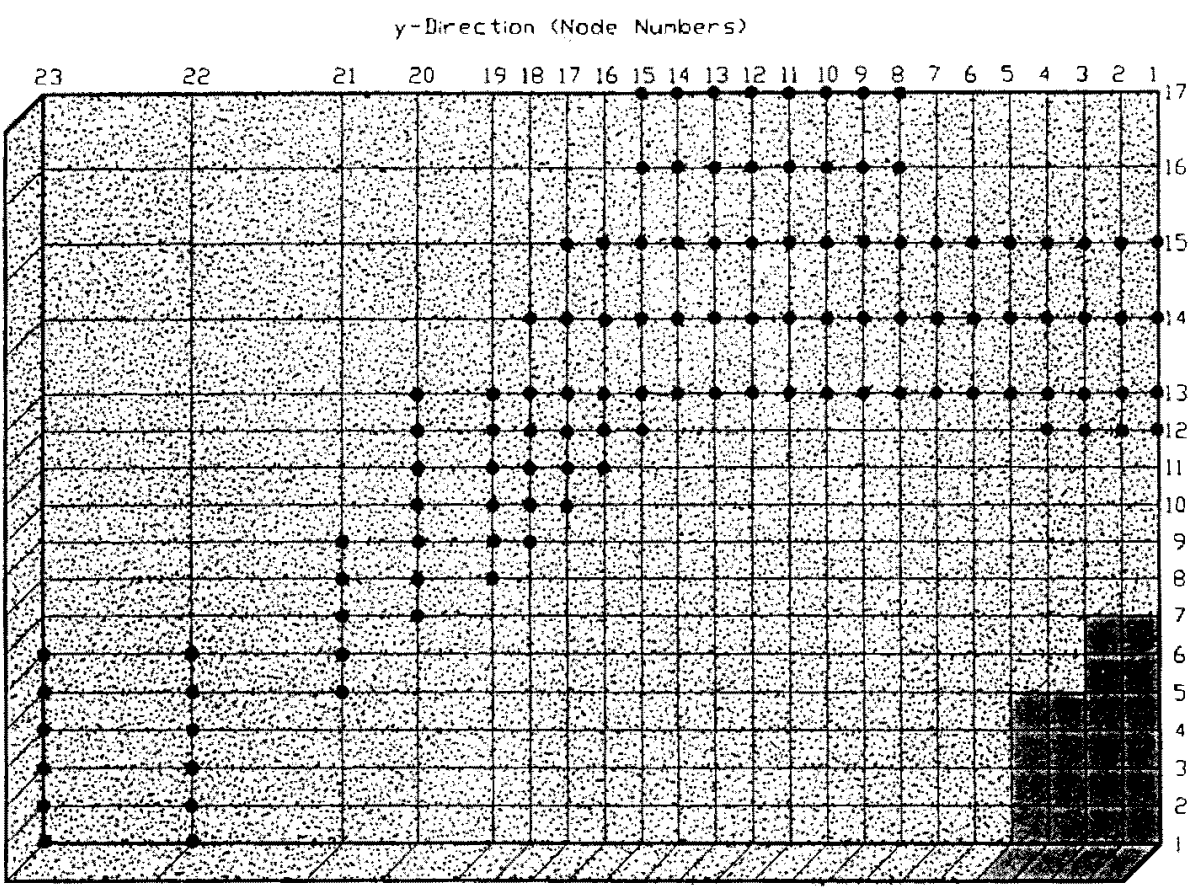

LEGEND

0 Mica Sand Unt

Bedrock/Bonney flock intrusive

- Boundery Condition Nodes Representing the Columbla River

LAYER 5 (EL. $-12 m--6 m$ ) 


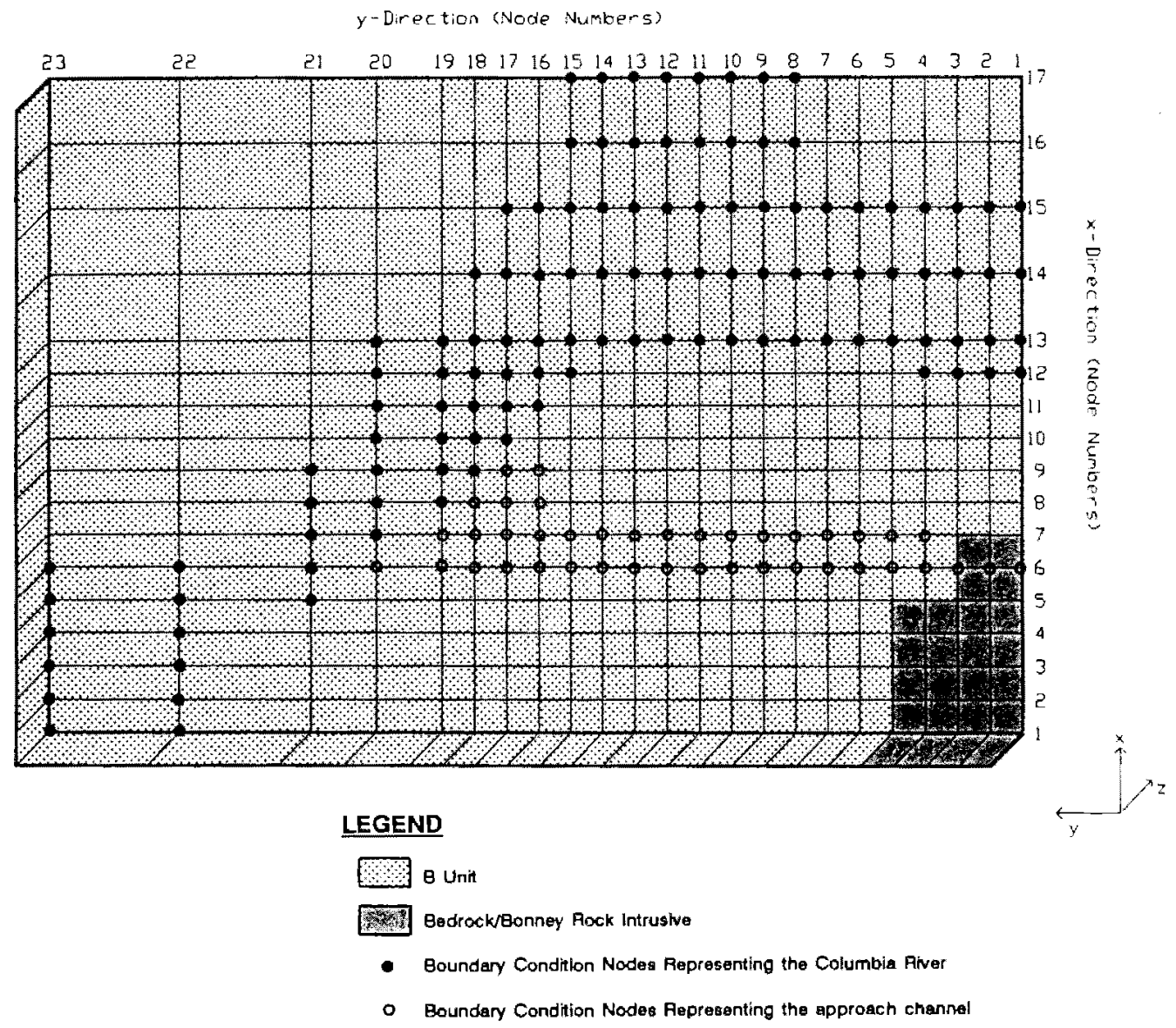

LAYER 6 (EL.-6m -- -12m) 
$y-$ Direction (Node Numbers?

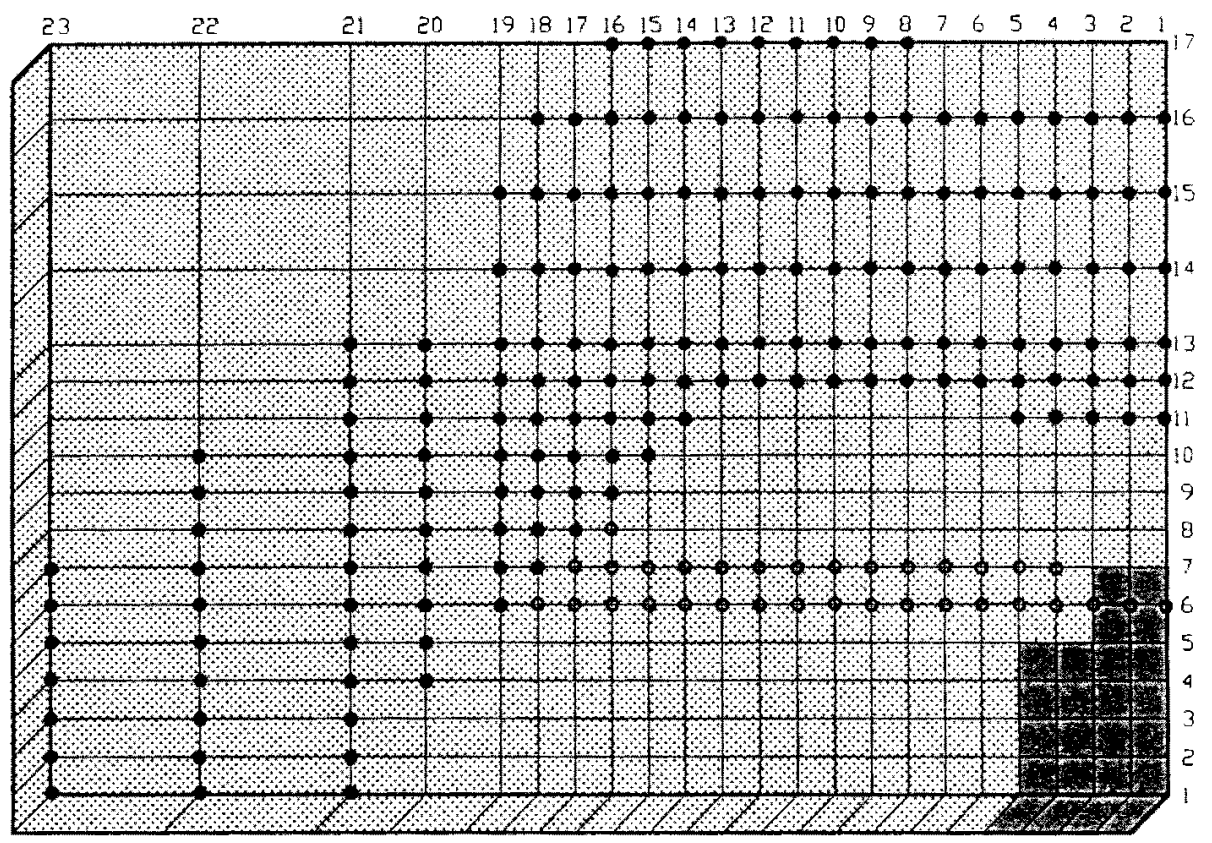

\section{LEGEND}

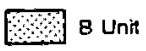

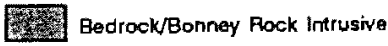

- Boundary Condition Nodes Representing the Columbis Fiver

- Boundary Condition Nodes Representing the aporosch channel 
$y$-Direction (Node Nimbers)

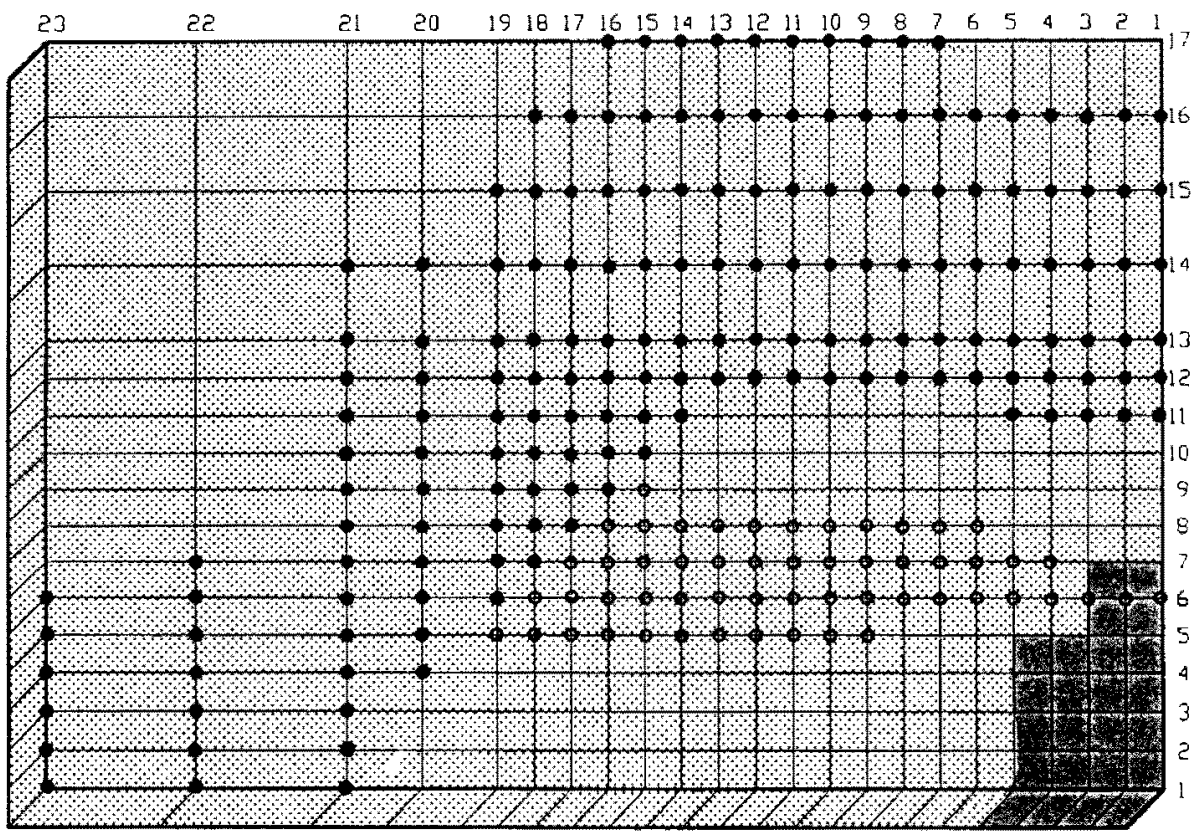

\section{LEGEND}

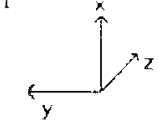

River Deposits/Fill

BedrockJionney Rlock Intrusive

- Boundary Condition Node Fepresenting the Columbia River

- Boundary Condition Nodes Representing the approach channel

LAYER 8 (EL. $5 \mathrm{~m}--0 \mathrm{~m})$ 